DEPARTMENT OF THE INTERIOR

UNITED STATES GEOLOGICAL SURVEY

GEORGE OTIS SMITH, DIRECTOR *

Water-SuPply PAPER 345-I

\title{
GAZETTEER OF SURFACE WATERS OF IOWA
}

BY

W. G. HOYT AND H. J. RYAN

Contributions to the Hydrology of the United States, 1914-I

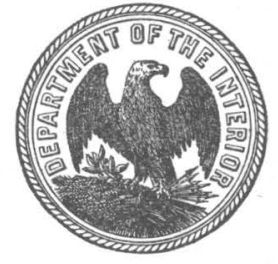

WASHINGTON.

GOVERNMENT PRINTING OFFICE

1915 


\title{
GAZETTEER OF SURFACE WATERS OF IOWA.
}

\author{
By W. G. Hoyt and H. J. RyaN.
}

This gazetteer embraces descriptions of all the streams named on the best available maps of Iowa, including the United States Geological Survey's base map of Iowa (scale 1 to 500,000), county maps published in the annual report of the Iowa Geological Survey, and the topographic atlas sheets of the United States Geological Survey.

Each stream is described as rising near the point at which its beginning is shown on the map. This method does not give results of great precision, and all statements of length and course are merely approximate.

The letter $L$ or $R$, in parentheses after the name of a stream, indicates that the stream is tributary from the left or right, respectively, to the stream into which it flows.

Abby Creek (L); Linn County; rises in T. 83 N., R. 5 W.; flows west 9 miles into Big Creek (tributary through Cedar River to Iowa River and thus to the Mississippi) in Linn County, T. 83 N., R. 6 W.

Ackley Creek (R); Floyd County; rises in T. 94 N., R. 18 W.; flows east 9 miles into Shellrock River (tributary through Cedar River to Iowa River and thus to the Mississippi) in Floyd County, T. 94 N., R. 17 W.

Aldrich Creek (R); Ida County; rises in sec. 5, T. 87 N., R. 41 W.; flows south 6 miles into Maple River (tributary through Little Sioux River to Missouri River) in sec. 33, T. 87 N., R. 41 W.

Alexander Creek (R); Fayette County; rises in sec. 9, T. 92 N., R. 8 W.; flows generally northwest 4 miles into Volga River (tributary through Turkey River to the Mississippi) in T. 93 N., R. 8 W.

Allaway Creek (L); Marshall County; rises in T. 82 N., R. 18 W.; flows south 10 miles into North Skunk River (tributary through Skunk River to the Mississippi) in Jasper County, T. 80 N., R. 18 W.

Allen Creek (L); Harrison County; rises in secs. 11 and 12, T. 81 N., R. 43 W.; flows southwest 15 miles into a slough west of Magnolia in Harrison County, T. 79 N., R. $44 \mathrm{~W}$.

Asher Creek (L); Grundy County; rises in T. 86 N., R. 18 W.; flows south 12 miles into Iowa River (tributary to the Mississippi) in Marshall County, T. 84 N., R. $18 \mathrm{~W}$.

Asher Creek (L); Marshall County; rises in sec. 4, T. 85 N., R. 18 W.; flows south 12 miles into Iowa River (tributary to the Mississippi) in Marshall County, sec. 27, T. 84 N., R. 18 W.

Asher Creek, Little (L); Marshall County; rises in sec. 8, T. 85 N., R. 17 W.; flows southwest 6 miles into Asher Creek (tributary through Iowa River to the Mississippi) in Marshall County, sec. 28, T. 85 N., R. 18 W. 
Ashton Creek (L); Ida County; rises in sec. 28, T. 89 N., R. 40 W.; flows northwest 9 miles into Little Sioux River (tributary to Missouri River) in Ida County, sec. 7, T. 89 N., R. $41 \mathrm{~W}$.

Avery Creek (R); Monroe County; rises in T. 72 N., R. 17 W.; flows northeast 19 miles into Des Moines River (tributary to the Mississippi) in Wapello County, T. 73 N., R. 15 W.

Avery Creek, South (R); Monroe County; rises in sec. 34, T. 72 N., R. 17 W.; flows northeast 20 miles into Des Moines River (tributary to the Mississippi) in sec. 31, T. 73 N., R. 14 W.

Bacon Creek (L); Ida County; rises in sec. 3, T. 88 N., R. 41 W.; flows west 12 miles into Little Sioux River (tributary to Missouri River) in Woodbury County, $\mathbf{T}$. 88 N., R. 43 W.

Badger Creek (L); Humboldt County; rises in T. 91 N., R. 28 W.; flows southwest 7 miles into Des Moines River (tributary to the Mississippi) in Webster County, sec. 30 , T. 90 N., R. $28 \mathrm{~W}$.

Badger Creek (L); Ida County; rises in sec. 2, T. 86 N., R. 40 W.; flows northwest 4 miles into Maple River (tributary through Little Sioux River to Missouri River) in Ida County, sec. 15, T. 87 N., R. 40 W.

Badger Creek (L); Madison County; rises in T. 77 N.; R. 27 W.; flows east and southeast 17 miles into North River (tributary through Des Moines River to the Mississippi) in Warren County, T. 77 N., R. 25 W.

Bailey Creek (R); Cerro Gordo County; rises in T. 94 N., R. 22 W.; flows southeast $20 \frac{1}{2}$ miles into West Fork of Shellrock River (tributary through Shellrock River to Cedar River, which discharges into the Mississippi through Iowa River) in junction with Beaver Dam Creek in Franklin County, T. 93 N., R. 19 W.

Ballard Creek (L); Pottawattamie County; rises in sec. 19, T. 77 N., R. 38 W.; flows southwest 2 miles into Bedell Creek (tributary through East Nishnabotna River to Nishnabotna River and thus to the Missouri).

Ballard Creek (R); Marion County; rises in sec. 7, T. 76 N., R. 20 W.; flows northeast 5 miles into Des Moines River (tributary to the Mississippi) in sec. 33, T. 77 N., R. $20 \mathrm{~W}$.

Ballard Creek (L); Story County; rises in T. 82 N., R. 24 W.; flows east $9 \frac{1}{2}$ miles into Skunk River (tributary to the Mississippi) in T. 82 N., R. 23 W.

Barber Creek (L); Clinton County; rises in sec. 23, T. 81 N., R. 2 E.; flows southeast 8 miles into Wapsipinicon River (tributary to the Mississippi).

Baskins Run (R); Bremer County; rises in sec. 30, T. 93 N., R. 13 W.; flows south 11 miles into Quarter Section Run (tributary through Cedar River to Iowa River and thus to the Mississippi) in sec. 34, T. 91 N., R. 13 W.

Bass Creek (R); Webster County; rises in sec. 10, T. 90 N., R. 29 W.; flows southeast $3 \frac{1}{2}$ miles into Des Moines River (tributary to the Mississippi) in Webster County, sec. 13, T. 90 N., R. 29 W.

Basswood Creek (R); Dubuque County; rises in T. 90 N., R 2 E.; flows north 4 miles into Mississippi River in Dubuque County, T. 90 N., R. 2 E. Total fall about 175 feet.

Battle Creek (R); Ida County; rises in sec. 33, T. 89 N., R. 41 W.; flows south 12 miles into Maple River (tributary through Little Sioux River to the Missouri) in Ida County, T. 87 N., R 41 W.

Beaman Creek (L); Carroll County; rises in T. 85 N., R. 36 W.; flows northwest 8 miles into Boyer River (tributary to the Missouri) in Sac County, T. 86 N., R. $37 \mathrm{~W}$.

Bear Creek (R); Boone County; rises in T. 83 N., R. 27 W.; flows southeast 6 miles into Des Moines River (tributary to the Mississippi) in Boone County, T. 83 N., R. $26 \mathrm{~W}$. 
Bear Creek (L); Buchanan County; rises in T. 88 N., R. 9 W., at altitude 930 feet; flows southwest 17 miles into Cedar River (tributary through Iowa River to the Mississippi) in Benton County, T. 86 N., R. 10 W.

Bear Creek (R); Cherokee County; rises in sec. 5, T. 92 N., R. 41 W.; flows northeast 5 miles into Mill Creek (tributary through Little Sioux River to the Missouri) in sec. 13, T. 93 N., R. 41 W.

Bear Creek (R); Clayton County; rises in T. 91 N., R. 5 W., at altitude 1,160 feet; flows east and north 9 miles into Volga River (tributary through Turkey River to the Mississippi) in Clayton County, T. 92 N., R. 4 W., at altitude 650 feet.

Bear Creek (R); Dallas County; rises in sec. 29, T. 78 N., R. 29 W.; flows east and northeast 8 miles into Raccoon River (tributary through Des Moines River to the Mississippi) in Dallas County, sec. 17, T. 78 N., R. 28 W.

Bear Creek (R); Delaware County; rises in T. 90 N., R. 3 W.; flows south into North Fork 'of Maquoketa River (tributary through Maquoketa River to the Mississippi) in Dubuque County, T. 89 N., R. 1 W.

Bear Creek $(\mathrm{R})$; formed in Delaware County by the union of two small branches in T. 89 N., R. 3 W., at altitude 1,050 feet above sea level, flows generally southeast 10 miles into North Fork of Maquoketa River (tributary through Maquoketa River to the Mississippi) in Dubuque County, T. 89 N., R. 1 W., at altitude 920 feet above sea level.

Bear Creek (R); Fayette County; rises in sec. 24, T. 92 N., R. 8 W.; flows northeast 7 miles into Volga River (tributary through Turkey River to the Mississippi) in Fayette County, sec. 26, T. 93 N., R. 7 W.

Bear Creek (L); Grundy County; rises in sec. 20, T. 87 N., R. 18 W.; flows southwest 10 miles into Iowa River (tributary to the Mississippi) in Hardin County, T. 86 N., R. 19 W.

Bear Creek (R); Guthrie County; rises in T. 79 N., R. 33 W.; flows east 9 miles into Wichita Creek (tributary through Raccoon River to Des Moines River and thus to the Mississippi) in Guthrie County, sec. 7, T. 79 N., R. 31 W.

Bear Creek (L); Hamilton County; rises in T. 86 N., R. $23 \mathrm{~W}$; flows south 6 miles and southwest $8 \frac{1}{2}$ miles into Skunk River (tributary to the Mississippi) in Story County, T. 84 N., R. 23 W.

Bear Creek (R); Jones County; rises in T. 85 N., R. 3 W., at altitude 960 feet above sea level; flows southeast 9 , east 13 , and northeast 5 miles into Maquoketa River (tributary to the Mississippi) in Jackson County, T. 84 N., R. 1 E., at altitude 700 feet above sea level.

Bear Creek (R); Poweshiek County; rises in T. 81 N., R. 16 W.; flows southeast 42 miles into Iowa River (tributary to the Mississippi) 1 mile north of Marengo in Iowa County, T. 81 N., R. 11 W.

Bear Creek (R); Van Buren County; rises in sec. 12, T. 68 N., R. 10 W.; flows east 6 miles into Des Moines River (tributary to the Mississippi) in Van Buren County, sec. 1, T. 68 N., R. 9 W.

Bear Creek (R); Wapello County; rises in sec. 7, T. 71 N., R. 15 W.; flows northeast 11 miles into Des Moines River (tributary to the Mississippi) in Wapello County, sec. 23, T. 72 N., R. 14 W.

Bear Creek (L); Winnebago County; rises in sec. 17, T. 98 N., R. 23 W.; flows southeast 6 miles into Lime Creek (tributary to the Mississippi through Cedar and Iowa rivers) in Hancock County, T. 97 N., R. 24 W.

Bear Creek (L); Winneshiek County; rises in T. 100 N., R. 8 W.; flows southeast 8 miles and east $8 \frac{1}{2}$ miles into Upper Iowa River (tributary to the Mississippi) in Allamakee County, T. 99 N., R. $6 \mathrm{~W}$.

Bear Creek, Little (R); Benton County; rises in T. 83 N., R. 10 W.; flows northeast 11 miles into Opossum Creek (tributary through Cedar River to Iowa River and thus to the Mississippi) in Benton County, sec. 24, T. 84 N., R. 9 W. 
Bear Creek, IIttle (R); Iowa County; rises in sec. 30 , T. 80 N., R. 12 W.; flows northeast 12 miles into Bear Creek (tributary through Iowa River to the Mississippi) in Iowa County, sec. 4, T. 80 N., R. 11 W.

Bear Creek, Little (R); Poweshiek County; rises in T. 80 N., R. 16 W.; flows east $17 \frac{1}{2}$ miles into Bear Creek (tributary through Iowa River to the Mississippi) in Poweshiek County, T. 80 N., R. 13 W.

Beaver Creek (R); Boone County; rises in T. 85 N., R. 28 W.; flows south 28 miles and southeast 28 miles into Des Moines River (tributary to the Mississippi) in Polk County, T. 79 N., R. 24 W.

Beaver Creek (R); Cerro Gordo County; rises in sec. 21, T. 95 N., R. 19 W.; flows east 9 miles into Shellrock River (tributary through Cedar River-to Iowa River and thus to the Mississippi) in Floyd County, T. 95 N., R. 18 W.

Beaver Creek (L); Crawford County; rises in T. 85 N., R. 39 W.; flows west $8 \frac{1}{2}$ miles into Soldier River (tributary to Missouri River) in Crawford County, T. 85 N., R. $41 \mathrm{~W}$.

Beaver Creek (R); Franklin County; rises in T. 90 N., R. 20 W.; flows southeast 6 and east 35 miles into Cedar River (tributary through Iowa River to the Mississippi) in Blackhawk County, T. 90 N., R. 14 W.

Beaver Creek (R); Guthrie County; rises in T. 78 N., R. 32 W.; flows east $11 \frac{1}{2}$ miles into South Raccoon River (tributary through Des Moines River to the Mississippi) in Guthrie County, sec. 5, T. 79 N., R. 30 W.

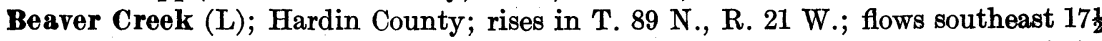
miles into South Fork of Iowa River (tributary through Iowa River to the Mississippi) in Hardin County, T. 87 N., R. 20 W.

Beaver Creek $(\mathrm{R})$; Howard County; rises in sec. 32, T. 100 N., R. 13 W.; flows east 8 miles into Upper Iowa River (tributary to the Mississippi) in Howard County, sec. 19, T. 100 N., R. 12 W. One small tributary from the right enters in sec. 25, T. 100 N., R. 13 W.

Beaver Creek (L); Humboldt County; rises in sec. 2, T. 91 N., R. 28 W.; flows southwest 8 miles into Des Moines River (tributary to the Mississippi) in Humboldt County, sec. 32 , T. 91 N., R. 28 W.

Beaver Creek (R); Jackson County; rises in T. 84 N., R. 6 E.; flows northeast 6 miles into Mississippi River.

Beaver Creek (L); Monona County; rises in sec. 28, T. 84 N., R. 43 W.; flows south and west 9 miles into Maple River (tributary through Little Sioux River to the Missouri) in sec. 16, T. 83 N., R. 44 W.

Beaver Creek (R); Palo Alto County; rises in T. 95 N., R. 33 W.; flows southeast 22 miles into West Des Moines River (tributary through Des Moines River to the Mississippi) in Pocahontas County, T. 93 N., R. 31 W.

Beaver Creek (L); Plymouth County; rises in sec. 36, T. 93 N., R. 48 W.; flows west 6 miles into Big Sioux River (tributary to the Missouri) in sec. 30, T. 93 N., R. $48 \mathrm{~W}$.

Beaver Creek (L); Winnebago County; rises in a small lake in T. 99 N., R. 23 W.; flows southeast 10 miles into Lime Creek (tributary through Shellrock River to Cedar River, which discharges into the Mississippi through Iowa River) in Worth County, sec. 34, T. 98 N., R. 22 W.

Beaver Creek, Middle Fork (R); Hardin County; rises in T. 89 N., R. 19 W.; flows southeast 12 miles and northeast 18 miles into Beaver Creek (tributary through Cedar River to Iowa River and thus to the Mississippi) in Grundy County, T. 89 N., R. 17 W.

Beaver Creek, North Fork (L); Grundy County; rises in sec. 10, T. 89 N., R. 18 W.; flows southeast 6 miles into Middle Fork of Beaver Creek (tributary through Shellrock River to Cedar River, which discharges into the Mississippi through Iowa River). 
Beaver Creek, South (R); Hardin County; rises in sec. 20, T. 89 N., R. 19 W.; flows southeast 12 miles and northeast 16 miles into Beaver Creek (tributary through Iowa River to the Mississippi) in sec. 27, T. 90 N., R. 17 W.

Beaver Creek, South Fork (R); Hardin County; rises in T. 89 N., R. 19 W.; flows east 15 miles into Middle Fork of Beaver Creek (tributary through Beaver Creek to Cedar River, which discharges into the Mississippi through Iowa River) in Grundy County, T. 89 N., R. 17 W.

Beaver Dam Creek (L); Cerro Gordo County; rises in T. 95 N., R. 22 W.; flows southeast 21 miles into Shellrock River (tributary through Cedar River to Iowa River and thus to the Mississippi) in junction with Bailey Creek in Franklin County, T. 93 N., R. 19 W.

Beaver Dam Creek, East Branch (L); Cerro Gordo County; rises in T. 95 N., R. $20 \mathrm{~W}$; flows south 12 miles into Beaver Dam Creek (tributary through Shellrock River to Cedar River, which discharges into the Mississippi through Iowa River) in sec. 21 , T. 94 N., R. 20 W.

Beaver Dam Creek, West Branch (R); Cerro Gordo County; rises in T. 94 N., R. $22 \mathrm{~W}$; f flows southeast 7 miles into Beaver Dam Creek (tributary through Shellrock River to Cedar River, which discharges into the Mississippi through Iowa River) in T. 94 N., R. 20 W.

Bedell Creek (L); Pottawattamie County; rises in sec. 5, T. 77 N., R. 38 W.; flows west 7 miles into East Branch of West Nishnabotna River (tributary through Nishnabotna River to the Missouri) in sec. 10, T. 77 N., R. 39 W.

Bee Branch (R); Monroe County; rises in sec. 29, T. 72 N., R. 18 W.; flows northeast 6 miles into Cedar Creek (tributary through Des Moines River to the Mississippi).

Bee Creek (L); Clarke County; rises in T. 71 N., R. 26 W.; flows south 8 miles into Long Creek (tributary through Grand River to the Missouri) in Decatur County, T. 70 N., R. 26 W.

Big Creek (R); Blackhawk County; rises in sec. 33, T. 87 N., R. 12 W.; flows northeast 6 miles through La Porte City into Cedar River (tributary through Iowa River to the Mississippi) in sec. 19, T. 87 N., R. 11 W.

Big Creek (L); Boone County; rises in T. 83 N., R. 25 W.; flows south 21 miles into Des Moines River (tributary to the Mississippi) in Polk County, T. 80 N., R. 25 W.

Big Creek (L); Henry County; rises in T. 72 N., R. 5 W.; flows southwest 4, northwest 10, and southeast 15 miles into Skunk River (tributary to the Mississippi) in Henry County, T. 70 N., R. 5 W.

Big Creek (L); Linn County; rises in T. 84 N., R. 5 W.; flows south 8 and southwest 7 miles into Cedar River (tributary through Iowa River to the Mississippi) in Linn County, T. 82 N., R. 6 W.

Big Creek (Wright Creek) (L); Woodbury County; rises in T. 88 N., R. 42 W.; flows northwest 6 miles and southwest 6 miles into Little Sioux River in Woodbury County, T. 88 N., R. 43 W.

Big Slough (R); Johnson County; rises in T. 78 N., R. 5 W.; flows southeast 8 miles into Wapsininoc Creek (tributary through Cedar River to Iowa River and thus to the Mississippi) in Muscatine County, sec. 2, T. 77 N., R. 4 W.

Big. (See also significant name.)

Big Fork. (See significant name.)

Black Cat. (See Black Creek, Emmet County.)

Bíack Creek (R); Audubon County; rises in T. 78 N., R. 36 W.; flows southwest $15 \frac{1}{2}$ miles into East Nishnabotna River (tributary through Nishnabotna River to the Missouri) 1 mile below Atlantic City, Cass County, T. 76 N., R. 36 W.

Black Creek (L); Wapello County; rises in sec. 14, T. 71 N., R. 12 W.; flows southeast 10 miles into Des Moines River (tributary to the Mississippi) in Van Buren County, sec. 17, T. 70 N., R. 11 W. 


\section{CONTRIBUtions TO HYDROLOGY OF UNITED STATES, 1914.}

Black Creek (Black Cat) (R); Emmet County; rises in T. 99 N., R. 31 W.; flows southeast 33 miles into East Des Moines River (tributary through Des Moines River to the Mississippi) in Kossuth County, T. 96 N., R. 29 W., 3 miles north of Algona.

Blackhawk Creek (R); Grundy County; rises in T. 88 N., R. 18 W.; flows northeast 10 , southeast 10 , and northeast 18 miles into Cedar River (tributary through Iowa River to the Mississippi) at Waterloo, Blackhawk County, T. 89 N., R. 13 W.

Blackhawk Creek (R); Scott County; rises in T. 78 N., R. 2 E.; flows east 6 miles into Mississippi River in Scott County, T. 77 N., R. 3 E.

Blackhawk Creek, North (L); Grundy County; rises in sec. 21, T. 89 N., R. 16 W.; flows southwest 18 miles into Blackhawk Creek (tributary through Des Moines River to the Mississippi) in sec. 1, T. 87 N., R. $15 \mathrm{~W}$.

Blood Run (L); rises in Rock County, Minn.; enters Iowa in Lyon County, T. 100 N., R. 48 W.; flows west 8 miles into Big Sioux River (tributary to the Missouri) in T. 100 N., R. 49 W.

Bloody Creek (R); Humboldt County; rises in sec. 25, T. 93 N., R. 30 W.; flows east $8 \frac{1}{2}$ miles into East Branch of Des Moines River (tributary through Des Moines River to the Mississippi) in Humboldt County, sec. 33, T. 93 N., R. 28 W.

Bloody Run (L); Dubuque County; rises in T. 90 N., R. 2 E.; flows south 5 miles into Little Maquoketa River (tributary to the Mississippi) at altitude 900 feet above sea level, in T. 90 N., R. 2 E., at altitude 620 feet above sea level.

Bluebell Creek (R); Dubuque County; rises in T. 90 N., R. 2. W.; flows north 6 miles into Turkey River (tributary to the Mississippi) in Clayton County, $\mathrm{T}$. 91 N., R. 2 W. Total fall, about 460 feet.

Blue Creek (L); formed by junction of two small branches in Benton County; T. 86 N., R. 9 W.; flows south 7 miles into Cedar River (tributary through Iowa River to the Mississippi) in Linn County, T. 85 N., R. 8 W.

Blue Earth River (R); Kossuth County; rises in T. 99 N., R. 30 W.; flows east 11 miles and north 4 miles into Minnesota through sec. 28, T. 100 N., R. 28 W. One branch formed by union of two small streams in sec. 11, T. 99 N., R. 29 W., flowing northeast in Faribault County, sec. 12, T. 100 N., R. 28 W.

Blue Earth River, East Fork (R); Winnebago County; rises in T. 100 N., R. 24 W.; flows west 19 miles and north $7 \frac{1}{2}$ miles through Kossuth County (T. 100 N., R. $28 \mathrm{~W}$.) into Minnesota.

Blue Earth River, West Fork (R); formed by union of two small streams in Kossuth County, sec. 11, T. 99 N., R. 29 W.; flows northeast 7 miles into a stream coming out of Union Slough, in sec. 9, T. 100 N., R. 28 W.

Bluff Creek (R); Boone County; rises in sec. 6, T. 85 N., R. 27 W.; flows south 11 miles into Des Moines River (tributary to the Mississippi) in Boone County, sec. 22 , T. 84 N., R. 27 W.

Bluff Creek (R); Monroe County; rises in sec. 15, T. 73 N., R. 17 W.; flows northeast and southeast 17 miles into Des Moines River (tributary to the Mississippi) in sec. 22, T. 74 N., R. $16 \mathrm{~W}$.

Boone River (L); Hancock County; rises in T. 96 N., R. 26 W.; flows south 8, southwest 5 , southeast 9 , southwest 7 , and southeast 43 miles to Webster City, thence southwest 24 miles into Des Moines River (tributary to the Mississippi) in Webster County, T. 87 N., R. 27 W. Storage is possible by the construction of a 26foot dam at Webster City which would impound 8,500 acre-feet.

Boone River, East Branch (L); Hancock County; rises in sec. 37, T. 96 N., R. 25 W.; flows south 18 miles into Middle Branch of Boone River (tributary through Des Moines River to the Mississippi) in Wright County, T. 93 N., R. 26 W.

Boone River, Middle Branch (L); Hancock County; rises in T. 95 N., R. 26 W.; flows south 9 miles into Boone River (tributary through Des Moines River to the Mississippi) in Wright County, T. 93 N., R. 26 W. 
Booth Creek (L); Plymouth County; rises in T. 90 N., R. 43 W.; flows southwest 12 miles into Little Sioux River (tributary to the Missouri) in Woodbury County, sec. 29 , T. 89 N., R. 44 W.

Boulder Creek (L); Linn County; rises in T. 86 N., R. 5 W.; flows southwest 6 miles into Buffalo Creek (tributary through Wapsipinicon River to the Mississippi).

Boyer River (L); Buena Vista County; rises in T. 90 N., R. 38 W.; flows southeast 16 miles, south 17 miles, and southwest 90 miles into Missouri River in Pottawattamie County, T. 76 N., R. 44 W.

Boyer River, East Fork (L); Carroll County; rises in T. 84 N., R. 36 W.; flows southwest 20 miles into Boyer River (tributary to Missouri River) at Denison, Crawford County, T. 83 N., R. 39 W.

Brewers Creek (R); Hamilton County; rises in T. 89 N., R. 26 W.; flows southeast 6 miles into Boone River (tributary through Des Moines River to the Mississippi) at Webster City, Hamilton County, T. 88 N., R. 25 W.

Bridge Creek (L); Keokuk County; rises in T. 77 N., R. 11 W.; flows south 10 miles into North Skunk River (tributary through Skunk River to the Mississippi) in sec. 18, T. 75 N., R. 11 W.

Britton Branch (R); Decatur County; rises in T. 69 N., R. 26 W.; flows southeast 4 miles into Little River in T. 68 N., R. 25 W.

Brockamp Creek (L); Winnebago County; rises in sec. 12, T. 96 N., R. 9 W.; flows southwest 4 miles into Turkey River (tributary to the Mississippi).

Broken Kettle Creek (L); Plymouth County; rises in T. 93 N., R. 47 W.; flows southwest 21 miles into Big Sioux River (tributary to Missouri River) in Plymouth County, T. 90 N., R. 48 W.

Brooke Creek (L); Buena Vista County; rises in T. 91 N., R. 37 W.; flows northwest $18 \frac{1}{2}$ miles into Little Sioux River (tributary to the Missouri) in Buena Vista County, T. 93 N., R. 38 W.

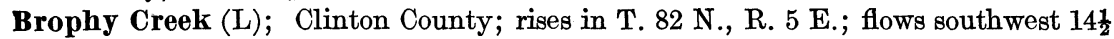
miles into Wapsipinicon River (tributary to the Mississippi) in Clinton County, T. 81 N., R. 5 E.

Brown Creek (L); Emmet County; rises in Grass Lake, T. 100 N., R. 33 W.; flows southeast 7 miles into West Des Moines River (tributary through Des Moines River to the Mississippi) in Emmet County, sec. 24, T. 99 N., R. 34 W.

Brush Creek (L); Des Moines County; rises in T. 70 N., R. 3 W.; flows southeast 10 miles into Skunk River (tributary to the Mississippi) in Des Moines County, T. 68 N., R. 3 W.

Brush Creek (R); Fayette County; rises in sec. 20, T. 92 N., R. 7 W.; flows northeast 4 miles into Bear Creek (tributary through Volga River to Turkey River and thus to the Mississippi).

Brush Creek (R); Fremont County; rises in sec. 14, T. 70 N., R. 42 W.; flows east 4 miles into West Nishnabotna River (tributary through Nishnabotna River to the Missouri) in Fremont County, sec. 20, T. 70 N., R. 41 W.

Brush Creek (L); Jackson County; rises in sec. 23, T. 86 N., R. 3 E.; flows southeast 11 miles into Maquoketa River (tributary to the Mississippi) in Jackson County, sec. 5, T. 84 N., R. 4 E.

Brush Creek (L); Jasper County; rises in T. 78 N., R. 20 W.; flows south $8 \frac{1}{2}$ miles into Des Moines River (tributary to the Mississippi) in Marion County, T. 76 N., R. $19 \mathrm{~W}$.

Brush Creek (R); Jasper County; rises in sec. 10, T. 81 N., E. 17 W.; flows north and northwest 10 miles into Timber Creek (tributary through Iowa River to the Mississippi) in sec. 4, T. 83 N., R. 17 W.

Brush Creek (R); Jefferson County; rises in sec. 1, T. 72 N; R. 10 W.; flows east 101 miles into Big Cedar Creek (tributary through Skunk River to the Mississippi) in Henry County, sec. 28, T. 71 N., R. 7 W. 
Brush Creek (L); Madison County; rises in T. 74 N., R. 26 W.; flows northeast 8 miles into South River (tributary through Des Moines River to the Mississippi) in Warren County, sec. 3, T. 74 N., R. 25 W.

Brush Creek (L); Wapello County; rises in T. 71 N., R. 15 W.; flows southeast 8 miles into Soap Creek (tributary through Des Moines River to the Mississippi) in Davis County, T. 70 N., R. 14 W.

Brush Creek (R); Wapello County; rises in sec. 14, T. 72 N., R. 13 W.; flows $4 \frac{1}{2}$ miles northeast into Cedar Creek (tributary through Skunk River to the Mississippi) in Wapello County, sec. 4, T. 72 N., R. 12 W.

Brushy Creek (L); Taylor County; rises in T. 68 N., R. 34 W.; flows south $9 \frac{1}{2}$ miles into Middle Fork of One Hundred and Two River in Taylor County, T. 67 N., R. $35 \mathrm{~W}$.

Brushy Creek (L); Webster County; rises in T. 90 N., R. 27 W.; flows south 24 miles into Des Moines River (tributary to the Mississippi) in Webster County, T. 87 N., R. $27 \mathrm{~W}$.

Brushy Fork (L); Carroll County; rises in T. 84 N., R. 36 W.; flows southeast 48 miles into South Raccoon River (tributary through Des Moines River to the Mississippi) in Guthrie County, T. 79 N., R. 31 W.

Buchanan Creek (L); Taylor County; rises in T. 68 N., R. 35 W.; flows southwest 10 miles into Nodaway River (tributary to the Missouri) in Page County, sec. 19, T. 67 N., R. $36 \mathrm{~W}$.

Buck Creek (L); Appanoose County; rises in sec. 1, T. 70 N., R. 18 W.; flows south 7 miles into Chariton River (tributary to Missouri River) in Appanoose County, sec. 36, T. 70 N., R. 18 W.

Buck Creek (R); Audubon County; rises in T. 78 N., R. 36 W.; flows south 12 miles into East Nishnabotna River (tributary through Nishnabotna River to the Missouri) in Cass County, T. 76 N., R. 36 W.

Buck Creek (R); Bremer County; rises in T. 93 N., R. 11 W.; flows south 26 miles into Little Wapsipinicon River (tributary through Wapsipinicon River to the Mississippi) in Buchanan County, T. 90 N., R. 10 W.

Buck Creek (R); Clayton County; rises in T. 94 N., R. 3 W. at altitude 1,140 feet above sea level; flows east and southeast 13 miles into Mississippi River in $T$. 93 N., R. 2 W. at altitude 620 feet above sea level.

Buck Creek (R); Jasper County; rises in sec. 9, T. 78 N., R. 20 W.; flows southeast 7 miles into Skunk River (tributary to the Mississippi) in Jasper County, sec. 22, T. 78 N., R. $19 \cdot \mathrm{W}$.

Buck Creek (L); formed by the junction of Buffalo and West creeks in Poweshiek County, T. 78 N., R. 16 W.; flows southeast 11 miles into North Skunk River (tributary through Skunk River to the Mississippi) in Mahaska County, T. 77 N., R. $15 \mathrm{~W}$.

Buck Creek (L); Wright County; rises in Wall Lake in T. 90 N., R. 24 W., flows southwest 11 miles into White Fox Creek (tributary through Boone River to Des Moines River and thus to the Mississippi) in Hamilton County, T. 89 N., R. 25 W., $1 \frac{1}{2}$ miles north of Webster City.

Buckeye Creek (R); Wapello County; rises in T. 72 N., R. 13 W.; flows northeast 8 miles into Cedar Creek (tributary through Skunk River to the Mississippi) in sec. 13, T. 72 N., R. 12 W.

Buckley Creek (L); Jasper County; rises in T. 78 N., R. 17 W.; flows south 9 miles into Skunk River in Mahaska County, T. 77 N., R. 17 W.

Buck Run (R); Carroll County; rises in sec. 22, T. 85 N., R. 34 W.; flows east 6 miles into Raccoon River (tributary through Des Moines River to the Mississippi) in sec. 20, T. 85 N., R. $33 \mathrm{~W}$.

Bud Creek (R); Scott County; rises in sec. 16, T. 79 N., R. 5 E.; flows northeast 4 miles into Mississippi River. 
Buffalo Creek (L); formed by union of east and west branches of Buffalo Creek in Buchanan County, T. 90 N., R. 8 W., at altitude 1,040 feet above sea level; flows southeast from the junction 42 miles into Wapsipinicon River (tributary to the Mississippi) at Anamosa, Jones County, T. 84 N., R. 4 W., at altitude 760 feet above sea level. Water power is developed at Anamosa, where a $6 \frac{1}{2}$-foot head creates 35 horsepower.

Buffalo Creek (R); Franklin County; rises in T. 93 N., R. 22 W.; flows 11 miles into Otter Creek (tributary through Hartgrave Creek to Cedar River which discharges into the Mississippi through Iowa River) in sec. 5, T. 92 N., R. 20 W.

Buffalo Creek (L); Ida County; rises in sec. 27, T. 88 N., R. 39 W.; flows west 5 miles into Maple River (tributary through Little Sioux River to the Missouri) in Ida County, sec. 1, T. 87 N., R. 40 W.

Buffalo Creek (L); Johnson County; rises in T. 80 N., R. 7 W.; flows southwest 4 miles into Clear Creek (tributary through Iowa River to the Mississippi).in Johnson County, T. 80 N., R. 7 W.

Buffalo Creek (R); Plymouth County; rises in T. 90 N., R. 43 W.; flows southeast 6 miles into Pierson Creek (tributary through Little Sioux River to the Missouri) in Cherokee County, sec. 33, T. 90 N., R. $42 \mathrm{~W}$.

Buffalo Creek (L); Poweshiek County; rises in sec. 18, T. 79 N., R. 15 W.; flows south 8 miles into Buck Creek (tributary through North Skunk River to Skunk River and thus to the Mississippi) in Poweshiek County, sec. 12, T. 78 N., R. $16 \mathrm{~W}$.

Buffalo Creek (L); Story County; rises in sec. 2, T. 82 N., R. 22 W.; flows southwest 4 miles into Indian Creek (tributary to Skunk River, which discharges into the Mississippi) in sec. 16, T. 82 N., R. 22 W.

Buffalo Creek (L); Winnebago County; rises in T. 98 N., R. 25 W.; flows southwest 25 miles into East Des Moines River (tributary through Des Moines River to the Mississippi) in Kossuth County, sec. 20, T. 97 N., R. 28 W.

Buffalo Creek, East Branch (L); Fayette County; rises in sec. 17, T. 91 N., R. 8 W.; flows southeast 14 miles, joining West Branch of Buffalo Creek to form Buffalo Creek (tributary to Wapsipinicon River, which discharges into the Mississippi) in sec. 35 , T. 90 N., R. $8 \mathrm{~W}$.

Buffalo Creek, Little (R); Winnebago County; rises in sec. 24, T. 99 N., R. 26 W.; flows southwest 13 miles into Buffalo Creek (tributary to East Des Moines River, which discharges into the Mississippi through Des Moines River) in Kossuth County, T. 97 N., R. 27 W.

Buffalo Creek, West Branch (R); Fayette County; rises in sec. 24, T. 91 N., R. 9 W.; flows southeast 12 miles, joining East Branch of Buffalo Creek to form Buffalo Creek (tributary to Wapsipinicon River, which discharges into the Mississippi) in sec. 35 , T. 90 N., R. 8 W.

Buffington Creek (R); Washington County; rises in T. 75 N., R. 6 W.; flows southeast 11 miles into Long Creek (tributary through Iowa River to the Mississippi) in Louisa County, T. 74 N., R. 5 W.

Buncombe Creek (L); Jackson County; rises in T. 87 N., R. 3 E.; flows southwest 7 miles into Lytle Creek (tributary through North Fork of Maquoketa River to Maquoketa River and thus to the Mississippi) in Dubuque County, T. 87 N., R. 2 E.

Burnett Creek (L); Marshall County; rises in T. 85 N., R. 17 W.; flows southwest 8 miles into Iowa River in Marshall County, sec. 24, T. 84 N., R. 18 W.

Burr Oak Branch (R); Davis County; rises in T. 69 N., R. 13 W.; flows east $5 \frac{3}{4}$ miles into South Chequest Creek in Davis County, sec. 15, T. 69 N., R. 12 W.

Burr Oak Creek (L); Jefferson County; rises in T. 73 N., R. 9 W.; flows southeast 8 miles into Walnut Creek in Jefferson County, T. 72 N., R. 8 W. 


\section{CONTRIBUTIONS TO HYDROLOGY OF UNITED STATES, 1914.}

Burr Oak Creek (R); Mitchell County; rises in sec. 5, T. 98 N., R. 16 W.; flows southeast 5 miles into Little Cedar River (tributary through Cedar River to Iowa River and thus to the Mississippi) in Mitchell County, sec. 12, T. 98 N., R. 16 W.

Butcher Creek (L); Marion County; rises in sec. 15, T. 76 N., R. 21 W.; flows southeast 6 miles into White Breast Creek (tributary through Des Moines River to the Mississippi) in Marion County, sec. 33, T. 76 N., R. 20 W.

Butcher Creek (R); Warren County; rises in sec. 9, T. 76 N., R. 23 W.; flows northeast 9 miles into Middle River (tributary through Des Moines River to the Mississippi) in Warren County, T. 77 N., R. 22 W.

Buttrick Creek (L); Greene County; formed by junction of east and west branches in T. 84 N., R. line 29 and 30; flows south 10 miles into Raccoon River (tributary through Des Moines River to the Mississippi) in Greene County, T. 83 N., R. 30 W.

Buttrick Creek, East Branch (L); Webster County; rises in T. 86 N., R. 29 W.; flows southwest $4 \frac{1}{2}$ miles and south 15 miles to junction with West Branch of Buttrick Creek (tributary to Raccoon River, which discharges into the Mississippi through Des Moines River) in Greene County, T. 84 N., line between Rs. 29 and 30 .

Buttrick Creek, West Branch (R); Webster County; rises in T. 88 N., R. 30 W.; flows south 24 miles to junction with East Branch of Buttrick Creek (tributary to Raccoon River, which discharges into the Mississippi through Des Moines River) in Greene County, T. 84 N., line between Rs. 29 and 30.

Calamus Creek (L); Clinton County; rises in sec. 1, T. 81 N., R. 2 E.; flows west 7 miles into Wapsipinicon River (tributary to the Mississippi).

Calamus Creek (L); Kossuth County; rises in sec. 28, T. 98 N., R. 30 W.; flows southeast 13 miles into Black Cat Creek (tributary through Des Moines River to the Mississippi) in Kossuth County, sec. 9, T. 96 N., R. 29 W.

Caleb Creek (L); Wayne County; rises in T. 69 N., R. 23 W.; flows southwest 14 miles into Weldon River (tributary through Grand River to the Missouri) in Decatur County, T. 67 N., R. 24 W.

Calhoun Creek (L); Jasper County; rises in T. 78 N., R. 21 W.; flows south $12 \frac{1}{2}$ miles into Des Moines River (tributary to the Mississippi) in Marion County, T. 77 N., R. $20 \mathrm{~W}$.

Calmus Creek (R); Cerro Gordo County; rises in sec. 12, T. 97 N., R. 22 W.; flows southeast 11 miles into Lime Creek (tributary through Shellrock River to Cedar River, which discharges into the Mississippi through Iowa River) at Mason City, sec. 3 , T. 96 N., R. 20 W.

Camp Creek (L); Calhoun County; rises in T. 89 N., R. 33 W.; flows south 17 miles into Raccoon River (tributary through Des Moines River to the Mississippi) in Calhoun County, T. 86 N., R. 34 W.

Camp Creek (R); Fremont County; rises in sec. 4, T. 69 N., R. 42 W.; flows east 5 miles into West Nishnabotna River (tributary through Nishnabotna River to the Missouri) in Fremont County, sec. 31, T. 70 N., R. 41 W.

Camp Creek (L); Polk County; rises in T. 79 N., R. 22 W.; flows south 15 miles into Des Moines River (tributary to the Mississippi) in Warren County, T. 77 N., R. $22 \mathrm{~W}$.

Camp Creek (L); Shelby County; rises in T. 78 N., R. 37 W.; flows southwest 11 miles into Indian Creek in Cass County, T. 77 N., R. 37 W.

Camp Creek (L); Woodbury County; rises in T. 88 N., R. 46 W.; flows southwest 5 miles into Whiskey Creek (tributary through West Fork of Little Sioux River to Little Sioux River, which discharges into the Missouri) in T. 87 N., R. 46 W.

Canoe Creek (L); Winneshiek County; rises in T. 100 N., R. 8 W.; flows south 5 miles and southeast $14 \frac{1}{2}$ miles into Upper Iowa River (tributary to the Mississippi) in Winneshiek County, T. 99 N., R. 7 W.

Carson Creek (L); Jasper County; rises in sec. 14, T. 79 N., R. 19 W.; flows south 5 miles into Skunk River (tributary to the Mississippi) in sec. 4, T. 78 N., R. 19 W. 
Carter Creek (R); Appanoose County; rises in T. 68 N., R. 16 W.; flows east 7 miles and southeast 10 miles through Davis County into Missouri, T. 67 N., R. 13 W.

Catfish Creek (R); Dubuque County; rises in T. 88 N., R. 2 E.; flows northeast 12 miles into Mississippi River 3 miles south of Dubuque in Dubuque County, T. 88 N., R. 4 E.

Catfish Creek, North Fork (L); Dubuque County; rises in T. 89 N., R. 2 E.; flows east 8 miles into Catfish Creek (tributary to the Mississippi) in Dubuque County, T. 88 N., R. 3 E.

Catfish Creek, South Fork (L); Dubuque County; rises in T. 88 N., R. 2 E.; flows northeast $8 \frac{1}{2}$ miles into Catfish Creek (tributary to the Mississippi) in Dubuque County, T. 88 N., R. 3 E.

Caton Creek (R); Boone County; rises in sec. 36 , T. 83 N., R. 27 W.; flows south 4 miles and southeast 4 miles into Des Moines River (tributary to the Mississippi) in Boone County, sec. 34, T. 82 N., R. 26 W.

Caxlan Creek (R); Clayton County; a small tributary to Turkey River, 3 miles long (tributary to the Mississippi), in T. 91 N., R. 3 W.

Cedar Branch (R); Monroe County; rises in sec. 32, T. 72 N., R. 17 W.; flows northwest 7 miles into Cedar Creek (tributary through Des Moines River to the Mississippi) in sec. 35 , T. 72 N., R. 18 W.

Cedar Creek (L); Calhoun County; rises in T. 89 N., R. 31 W.; flows south 27 miles into Raccoon River (tributary through Des Moines River to the Mississippi) in Greene County, T. 85 N., R. 32 W.

Cedar Creek (R); Clay County; rises in T. 94 N., R. 35 W.; flows east and southeast 11 miles through Rush Lake, Palo Alto County, into North Branch of Lizard Creek (tributary through Lizard Creek to Des Moines River and thus to the Mississippi) in Pocahontas County, T. 93 N., R. 33 W.

Cedar Creek (L); Des Moines County; rises in sec. 22, T. 72 N., R. 4 W.; flows south 9 miles into Flint River (tributary to the Mississippi) in Des Moines County, sec. 28, T. 71 N., R. 4 W.

Cedar Creek (R); Lucas County; rises in T. 71 N., R. 22 W.; flows northeast 18 miles, northwest 36 miles into Des Moines River (tributary to the Mississippi) in Mahaska County, T. 75 N., R. 17 W. (Part of this creek is called Coal Creek on the Monroe County map, Iowa Geol. Survey Ann. Rept., vol. 13.)

Cedar Creek (R); Madison County; rises in sec. 29, T. 76 N., R. 28 W.; flows east 15 miles into North River (tributary through Des Moines River to the Mississippi) in Madison County, sec. 9, T. 76 N., R. 26 W.

Cedar Creek (L); Mahaska County; rises in T. 77 N., R. 14 W.; flows southeast $18 \frac{1}{2}$ miles into North Skunk River (tributary through Skunk River to the Mississippi) in Keokuk County, sec. 15, T. 75 N., R. 12 W.

Cedar Creek (R); Mahaska County; rises in T. 74 N., R. 15 W.; flows southeast $64 \frac{1}{2}$ miles into Skunk River (tributary to the Mississippi) in Henry County, T. 71 N., R. 7 W.

Cedar Creek (R); Pocahontas County; rises in T. 93 N., R. 34 W.; flows south 33 miles and southwest 6 miles into Raccoon River (tributary through Des Moines River to the Mississippi) 1 mile below Sac City in Sac County, T. 88 N., R. 36 W.

Cedar Creek (R); Washington County; rises in T. 75 N., R. 9 W.; flows southeast 8 miles into West Fork of Crooked Creek (tributary through Crooked Creek to Skunk River and thus to the Mississippi) in Washington County, T. 75 N., R. 7 W.

Cedar Creek, East (L); Calhoun County; rises in T. 89 N., R. 31 W.; flows south $21 \frac{1}{2}$ miles into Cedar Creek (tributary through Iowa River to the Mississippi) in junction with West Cedar Creek in Calhoun County, T. 87 N., R. 31 W.

Cedar Creek, Little (R); Pocahontas County; rises in T. 93 N., R. 34 W.; flows south 22 miles into Cedar Creek (tributary through Raccoon River to Des Moines River and thus to the Mississippi) in Pocahontas County, T. 91 N., R. 34 W. 


\section{CONTRIBUTIONS TO HYDROLOGY OF UNITED STATES, 1914.}

Cedar Creek, Little (R); Van Buren County; rises in sec. 30, T. 70 N., R. 8 W.; flows southeast 9 miles and north 9 miles into Cedar Creek (tributary through Skunk River to the Mississippi) in Henry County, T. 70 N., R. 7 W.

Cedar Creek, Iittle (R); Wapello County; rises in sec. 27, T. 73 N., R. 14 W.; flows east 8 miles into Cedar Creek (tributary through Iowa River to the Mississippi) in Wapello County, sec. 26, T. 73 N., R. 13 W.

Cedar Creek, North (L); Lucas County; rises in T. 72 N., R. 20 W.; flows northeast 9 miles into Cedar Creek (tributary through Des Moines River to the Mississippi) in Marion County, T. 74 N., R. 18 W.

Cedar Creek, West (R); Calhoun County; rises in T. 89 N., R. 32 W.; flows south 19 miles into Cedar Creek (tributary through Iowa River to the Mississippi) in junction with East Cedar Creek in Calhoun County, T. 87 N., R. 31 W.

Cedar River (L); Dodge County, Minn.; rises in T. 105 N., R. 17 W.; flows south, entering Iowa in Mitchell County, T. 100 N., R. 18 W.; flows southeast and south 230 miles into Iowa River (tributary to the Mississippi) in Louisa County, T. 75 N., R. 4 W. Gaging station at Cedar Rapids, 1902-1913. Water power is developed at ten localities. At Waverly a 9 -foot head creates 280 horsepower; at Otranto station a 7-foot head creates 230 horsepower; at West Mitchell there are three plants-two with 7-foot heads, creating 60 horsepower each, and one with $7 \frac{1}{2}$-foot head creating 75 horsepower; at Nashua a 10-foot head creates 250 horsepower; at Cedar Rapids a 6-foot head creates 300 horsepower; at Brownville a 9-foot head creates 60 horsepower; at Staceyville an 8-foot head creates 35 horsepower. There are also two plants (one at Osage and one at Ansgar) from which no data are available.

Cedar River, Little (L); Mower County, Minn.; rises in sec. 9, T. 102 N., R. 16 W.; flows into Iowa in Mitchell County, T. 100 N., R. 16 W.; flows south 46 miles directly into Cedar River (tributary through Iowa River to the Mississippi) in Chickasaw County, T. 94 N., R. 14 W.

Chaboneau Creek (R); Mills County; rises in T. 71 N., R. 43 W.; flows southeast 3 miles into Wabonsie Creek (tributary to Missouri River).

Chances Creek (R); Ringgold County; rises in T. 69 N., R. 29 W.; flows south $3 \frac{1}{2}$ miles into West Fork of Grand River in Ringgold County, T. 69 N., R. 29 W.

Chariton River (L); Clarke County; rises in T. 71 N., R. 25 W.; flows northeast 28 miles to Chariton and southeast $51 \frac{1}{2}$ miles into the State of Missouri through Appanoose County, T. 67 N., R. 16 W., emptying into Missouri River.

Chariton River, South (R); Wayne County; rises in sec. 17, T. 68 N., R. 22 W.; flows north 8 miles, east 14 miles, and northeast 11 miles into Chariton River (tributary to Missouri River) in Appanoose County, T. 70 N., R. 19 W.

Chequest Creek $(R)$; formed by the union of North and South forks in Davis

- County, T. 69 N., R. 12 W.; flows east 9 miles, northeast 6 miles, southeast 9 miles, and east 9 miles, into Des Moines River (tributary to the Mississippi) in Van Buren County, T. 69 N., R. 10 W.

Chequest Creek, North (L); Davis County; rises in sec. 31, T. 70 N., R. 14 W.; flows 7 miles into Chequest Creek (tributary through Des Moines River to the Mississippi) in Davis County, T. 69 N., R. 12 W.

Chequest Creek, South (R); Davis County; rises in T. 69 N., R. 13 W.; flows east $10 \frac{1}{2}$ miles into Chequest Creek (tributary through Des Moines River to the Mississippi) in Davis County, sec. 12, T. 69 N., R. 12 W.

Cherry Creek (R); Clinton County; rises in T. 82 N., R. 4 E.; flows southeast 6 miles into Brophy Creek (tributary through Wapsipinicon River to the Mississippi) in Clinton County, sec. 17, T. 81 N., R. 5 E.

Cherry Creek (L); Jasper County; rises in sec. 30, T. 81 N., R. 19 W.; flows south 12 miles into Skunk River (tributary to the Mississippi) in Jasper County, sec. 29, T. 79 N., R. 19 W. 
Chicken Creek (R); Marshall County; rises in sec. 19, T. 85 N., R. 18 W.; flows southeast 6 miles into Asher Creek (tributary through Iowa River to the Mississippi) in Marshall County, sec. 16, T. 84 N., R. 18 W.

Clanton Creek (R); Madison County; rises at Macksburg, in T. 74 N., R. 29 W.; flows east 14 miles and northeast $16 \frac{1}{2}$ miles into Middle River (tributary through Des Moines River to the Mississippi) in Warren County, T. 76 N., R. 25 W.

Clanton Creek, South (R); Madison County; rises in T. 74 N., R. 28 W.; flows east $10 \frac{1}{2}$ miles into Clanton Creek (tributary through Middle River to Des Moines River and thus to the Mississippi) in Madison County, sec. 15, T. 74 N., R. 27 W.

Clear Creek (R); Boone County; rises in T. 84 N., R. 25 W.; flows southeast $8 \frac{1}{2}$ miles into Squaw Creek (tributary through Skunk River to the Mississippi) 2 miles northwest of Ames, Story County, T. 83 N., R. 24 W.

Clear Creek (R); Cerro Gordo County; rises in Clear Lake, T. 96 N., R. 22 W.; flows east 10 miles into Lime Creek, sec. 3, T. 96 N., R. 20 W., at Mason City. (Called Crane Creek on map of Cerro Gordo County.)

Clear Creek (R); Iowa County; rises in T. 80 N., R. 10 W.; flows east 24 miles into Iowa River (tributary to the Mississippi) 2 miles north of Iowa City in Johnson County, T. 79 N., R. 6 W.

Clear Creek (L); Keokuk County; rises in T. 76 N., R. 10 W.; flows south 9 miles into Skunk River (tributary to the Mississippi) in Keokuk County, sec. 34, T. 75 N., R. 10 W.

Clear Creek (R); Marshall County; rises in T. 83 N., R. 20 W.; flows southeast 16 miles into North Skunk River (tributary through Skunk River to the Mississippi) in Jasper County, T. 81 N., R. 21 W.

Clear Creek (R); Plymouth County; rises in T. 92 N., R. 43 W.; flows south 19 miles into West Fork of Little Sioux River (tributary through Little Sioux River to the Missouri) in Plymouth County, T. 90 N., R. 44 W.

Clear Creek (L); Story County; rises in T. 83 N., R. 21 W.; flows southeast 8 miles, south 10 miles, and southwest 4 miles into Indian Creek (tributary through Skunk River to the Mississippi) in Jasper County, T. 80 N., R. 21 W.

Clemons Creek (R); Washington County; rises in sec. 6, T. 75 N., R. 8 W.; flows southeast 6 miles into Crooked Creek (tributary through Skunk River to the Mississippi).

Clole Branch (R); Dubuque County; rises in T. 89 N., R. 2 E.; flows northeast 4 miles into Little Maquoketa River (tributary to the Mississippi) in Dubuque County, T. 89 N., R. 3 E. Total fall, about 200 feet.

Coal Creek (L); Keokuk County; rises in sec. 8, T. 76 N., R. 13 W.; flows southeast

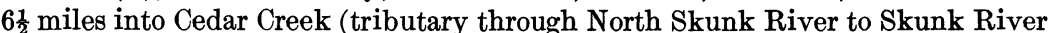
and thus to the Mississippi) in Keokuk County, sec. 36, T. 76 N., R. 13 W.

Coal Creek (R); Mahaska County; rises in T. 74 N., R. 17 W.; flows northeast 7 miles into Des Moines River (tributary to the Mississippi) in Mahaska County, T. 74 N., R. 17 W.

Coal Creek (R); Monroe County; rises in sec. 17, T. 71 N., R. 17 W.; flows northeast and northwest 7 miles into Cedar Creek (tributary through Des Moines River to the Mississippi) in sec. 18, T. 72 N., R. $17 \mathrm{~W}$.

Coal Creek (R); Warren County; rises in T. 75 N., R. 22 W.; flows northeast 10 miles and north 11 miles into South River (tributary through Des Moines River to the Mississippi) in Warren County, T. 77 N., R. 22 W.

Coal Creek, South (R); Mahaska County; rises in T. 74 N., R. 17 W.; flows northeast $6 \frac{1}{4}$ miles into Coal Creek (tributary through Des Moines River to the Mississippi) in Mahaska County, T. 74 N., R. 17 W.

Coates Creek (L); Van Buren County; rises in sec. 6, T. 69 N., R. 8 W.; flows south 8 miles into Des Moines River (tributary to the Mississippi) in Van Buren County, sec. 8 , T. 68 N., R. 8 W. 
Cold Water Creek (R); Cerro Gordo County; rises in sec. 7, T. 94 N., R. 19 W.; flows southeast 24 miles into Shellrock River (tributary through Cedar River to Iowa River and thus to the Mississippi) in Butler County, T. 93 N., R. 16 W.

College Creek (R); Story County; rises in sec. 7, T. 83 N., R. 24 W.; flows northeast 3 miles and southeast $2 \frac{1}{2}$ miles into Squaw Creek (tributary through Skunk River to the Mississippi) in Story County, sec. 3, T. 83 N., R. 24 W.

Competine Creek (L); Keokuk County; rises in T. 74 N., R. 12 W.; flows southeast 6 miles into Cedar Creek (tributary through Skunk River to the Mississippi) in Jefferson County, T. 72 N., R. 11 W.

Competine Creek, East (L); Jefferson County; rises in T. 73 N., R. 11 W.; flows south 9 miles into West Competine Creek (tributary through Cedar Creek to Skunk River and thus to the Mississippi) in Jefferson County, sec. 21, T. 72 N., R. 11 W.

Competine Creek, West (L); Jefferson County; rises in T. 73 N., R. 11 W.; flows south 8 miles into Cedar Creek (tributary through Skunk River to the Mississippi) in Jefferson County, T. 72 N., R. 11 W.

Contention Creek (R); Scott County; rises in T. 80 N., R. 3 E.; flows north 6 miles into Wapsipinicon River (tributary to the Mississippi) in Scott County, T. 80 N., R. $3 \mathrm{E}$.

Cookoo Creek (L); Monroe County; rises in sec. 28, T. 73 N., R. 19 W.; flows northeast 5 miles into Cedar Creek, sec. 7, T. 73 N., R. 18 W.

Coon Creek (L); Iowa County; rises in sec. 4, T. 81 N., R. 12 W.; flows southeast 5 miles into Iowa River (tributary to the Mississippi) in sec. 13, T. 81 N., R. 11 W.

Coon River. (See Raccoon River.)

Cooper Creek (R); Wayne County; rises in T. 68 N., R. 20 W.; flows east 19 miles into Chariton River (tributary to Missouri River) in Appanoose County, sec. 21, T. 69 N., R. $17 \mathrm{~W}$.

Copper Creek (R); Jackson County; rises in T. 84 N., R. 5 E.; flows northwest 5 miles into Deep Creek (tributary through Maquoketa River to the Mississippi).

Cotton Creek (L); Warren County; rises in T. 74 N., R. 23 W.; flows northeast 8 miles into White Breast River (tributary through Des Moines River to the Mississippi) in sec. 27 , T. 74 N., R. $22 \mathrm{~W}$.

Cottonwood Creek (L); Woodbury County; rises in sec. 21, T. 86 N., R. 44 W.; flows west 5 miles into Wolf Creek (tributary through West Fork of Little Sioux River to Little Sioux River and thus to the Missouri) in Woodbury County, sec. 35, T. 86 N., R. $45 \mathrm{~W}$.

Cox Creek (R); Clayton County; rises in T. 91 N., R. 5 W., at altitude 1,200 feet; flows north 9 miles into Volga River in Clayton County, T. 92 N., R. 3 W., at altitude 720 feet.

Crabapple Creek (L); Linn County; rises in T. 85 N., R. 6 W.; flows south $7 \frac{1}{2}$ miles into Big Creek (tributary through Cedar River to Iowa River and thus to the Mississippi) in Linn County, T. 83 N., R 5 W.

Crane Creek (R); Bremer County; rises in T. 93 N., R. 13 W.; flows southeast $8 \frac{1}{2}$ miles, south 10 miles, and southeast $10 \frac{1}{2}$ miles into Wapsipinicon River (tributary to the Mississippi) in Blackhawk County, T. 90 N., R. 11 W.

Crane Creek (R); Cerro Gordo County; rises in sec. 34, T. 96 N., R. 21 W.; flows northeast 5 miles into Willow Creek (tributary through Lime Creek to Shellrock River, a branch of Cedar River, which discharges into the Mississippi through Iowa River).

Crane Creek (R); Howard County; rises in T. 99 N.; R. 14 W.; flows southeast 40 miles and east 4 miles into Little Turkey River (tributary through Turkey River to the Mississippi) in Fayette County, T. 95 N., R. 10 W. At Alpha an 11 $\frac{1}{2}$-foot head develops 100 horsepower.

Crooked Creek (L); Cedar County; rises in T. 80 N., R. 2 W., at Tipton; flows southeast 10 miles into Cedar River (tributary through Iowa River to the Mississippi) in Cedar County, sec. 13, T. 79 N., R. 3 W. 
Crooked Creek (L); Hamilton County; rises in sec. 36, T. 87 N., R. 26 W.; flows south $5 \frac{3}{4}$ miles into Squaw Creek (tributary through Skunk River to the Mississippi) in Hamilton County, sec. 25, T. 86 N., R. 26 W.

Crooked Creek $(\mathrm{R})$; Ringgold County; rises in T. 70 N., R. 29 W.; flows southeast 10 miles into West Grand River in Ringgold County, T. 68 N., R. 30 W.

Crooked Creek (R); Taylor County; rises in T. 70 N., R. 33 W.; flows south 3 miles into Middle Fork of One Hundred and Two River in Taylor County, T. 70 N., R. $33 \mathrm{~W}$.

Crooked Creek (L); Washington County; formed by junction of East and West forks of Crooked Creek in T. 74 N., R. 7 W.; flows southwest 9 miles into Skunk River (tributary to the Mississippi) in Washington County, T. 74 N., R. 7 W.

Crooked Creek (R); Webster County; rises in sec. 5, T. 87 N., R. 28 W.; flows east 5 miles into Des Moines River (tributary to the Mississippi) in sec. 18, T. 87 N., R. $27 \mathrm{~W}$.

Crooked Creek, East Fork (L); Des Moines County; rises in T. 72 N., R. 4 W.; flows northeast 17 miles into Crooked Creek (tributary through Skunk River to the Mississippi) in Washington County, T. 74 N., R. 7 W.

Crooked Creek, West Fork (R); Keokuk County; rises in T. 77 N., R. 10 W.; flows southeast 30 miles into Crooked Creek (tributary through Skunk River to the Mississippi) in Washington County, T. 74 N., R 7 W.

Crow Creek (R); Scott County; rises in sec. 18, T. 79 N., R. 4 E.; flows southeast 13 miles into Mississippi River in Scott County, sec. 24, T. 78 N., R. 4 E.

Crow Creek (R); Warren County; rises in T. 75 N., R. 22 W.; flows north 11 miles into Coal Creek (tributary through South River to Des Moines River and thus to the Mississippi) in Marion County, T. 76 N., R. 21 W.

Curran Branch (R); Dubuque County; rises in T. 88 N., R. 1 W.; flows southeast 6 miles into Whitewater Creek (tributary through North Fork of Maquoketa River to Maquoketa River and thus to the Mississippi) in Dubuque County, T. 87 N., R. 1 E.

Cylinder Creek (L); Palo Alto County; rises in Medium Lake, T. 96 N., R. 32 W.; flows southeast and south 12 miles into Des Moines River (tributary to the Mississippi) in Palo Alto County, sec. 30, T. 95 N., R. 31 W.

Davids Creek (L); Audubon County; rises in T. 80 N., R. 34 W.; flows southwest 16 miles into East Nishnabotna River (tributary to Nishnabotna River, which discharges into the Missouri) in Audubon County, T. 78 N., R. 35 W.

Davis Creek (R); Washington County; rises in T. 76 N., R. 7 W.; flows east 12 miles into Iowa River (tributary to the Mississippi) in Washington County, sec. 36, T. 77 N., R. 6 W.

Dead Mans Run (R); Woodbury County; rises in sec. 3, T. 88 N., R. 46 W.; flows south and southeast 5 miles into a swamp in the headwaters of Whiskey Creek (tributary through West Fork of Little Sioux River to Little Sioux River and thus to the Missouri) in sec. 22 , T. 88 N., R. $46 \mathrm{~W}$.

Deep Creek $(\mathrm{R})$; a creek 2 miles long which rises in Clayton County and flows in a southeasterly direction into Volga River (tributary through Turkey River to the Mississippi).

Deep Creek (R); Clinton County; rises in T. 82 N., R. 4 E.; flows northeast 18 miles into Maquoketa River (tributary to the Mississippi) in Jackson County, T. 84 N., R. 5 E.

Deep Creek (L); Iowa County; rises in T. 79 N., R. 12 W.; flows south $4 \frac{1}{2}$ miles into North English River (tributary through English River to Iowa River and thus to the Mississippi) in T. 79 N., R. 12 W.

Deep Creek (L); Sioux County; rises in T. 94 N., R. 43 W.; flows southwest 13, west 7, and southwest 3 miles into Floyd River (tributary to the Missouri) at Le Mars, T. 92 N., R $45 \mathrm{~W}$.

$$
77145^{\circ}-15-2
$$


Deep River (R); Poweshiek County; rises in T. 79 N., R. 15 W.; flows southeast $17 \frac{1}{2}$ miles into North English River (tributary through English River to Iowa River and thus to the Mississippi) in Iowa County, T. 78 N., R. 12 W.

Deer Creek (R); Guthrie County; rises in sec. 21 , T. 78 N., R. 31 W.; flows east 7 miles into South Raccoon River (tributary through Raccoon River to Des Moines River and thus to the Mississippi) in Guthrie County, sec. 15, T. 78 N., R. 30 W.

Deer Creek (L); Iowa County; rises in T. 78 N., R. 9 W.; flows east 6 miles into English River (tributary through Iowa River to the Mississippi) in Washington County, T. 77 N., R. 8 W.

Deer Creek (R); John\$on County; rises in sec. 35, T. 80 N., R. 8 W.; flows east $7 \frac{1}{2}$ miles into Clear Creek (tributary through Iowa River to the Mississippi) in Johnson County, sec. 1, T. 79 N., R. 7 W.

Deer Creek (L); Mills County; rises in sec. 33, T. 72 N., R. 40 W.; flows southwest 10 miles into West Nishnabotna River (tributary through Nishnabotna River to the Missouri) in Fremont County, T. 70 N., R. 41 W.

Deer Creek (R); rises in Freeborn County, Minn.; flows southeast into Worth County, T. 100 N., R. 19 W.; continuing southeast 14 miles into Cedar River (tributary through Iowa River to the Mississippi) in Mitchell County, T. 99 N., R. 18 W.

Deer Creek (R); Plymouth County; rises in sec. 29, T. 91 N., R. 43 W.; flows south 5 miles into West Fork of Little Sioux (tributary through Little Sioux River to the Missouri) in T. 90 N., R. $43 \mathrm{~W}$.

Deer Creek (L); Tama County; rises in T. 85 N., R. 16 W.; flows southeast 14 miles to Toledo; continuing southeast 4 miles into Iowa River (tributary to the Mississippi) at Tama, T. 83 N., R. $15 \mathrm{~W}$.

Deer Creek (R); Webster County; rises in sec. 4, T. 90 N., R. 30 W.; flows southeast 12 miles into Des Moines River (tributary to the Mississippi) in Webster County, T. 90 N., R. $29 \mathrm{~W}$.

Deer Creek (L); Woodbury County; rises in sec. 19, T. 88 N., R. 45 W.; flows southwest 5 miles into Elliott Creek (tributary through Whiskey Creek to West Fork of Little Sioux River, which discharges into the Missouri through Little Sioux River).

Des Moines River $(R)$; formed by junction of East and West branches of Des Moines River in Humboldt County, T. 91 N., R. 28 W.; flows south 14 miles to Fort Dodge, continuing southeast 95 miles to Des Moines, southeast 93 miles to Ottumwa, and continuing 91 miles in the same direction to Keokuk, where it discharges into the Mississippi River in Lee County, T. 65 N., R. 5 W. At Des Moines a 9-foot head is utilized, developing about 200 horsepower. Gaging stations at Fort Dodge 1905-6; Des Moines 1902-3, 1905, 1909, 1913; Keosauqua 1903, 1906, 1910, 1913.

Des Moines River, East Fork (L); rises in Martin County, Minn., T. 102 N., R. 33 W.; enters Iowa in Emmet County, T. 100 N., R. 32 W.; flows southeast 40 miles, south 11 miles to Algona, and continues south $39 \frac{1}{2}$ miles into Des Moines River (tributary to the Mississippi) in junction with West Des Moines River in Humboldt County, T. 91 N., R. 28 W. Water power is developed at Dakota City, where a 7-foot head is utilized, creating about 50 horsepower.

Des Moines River, West Fork (R); rises in Martin County, Minn.; flows into Emmet County, T. 100 N., R. 34 W.; flows southeast 8 miles to Estherville, continuing southeast 96 miles into Des Moines River, and meeting East Des Moines River in Humboldt County, T. 91 N., R. 28 W. Water power is developed at Rutland, where a 10-foot head is utilized, developing about 100 horsepower, and at Humboldt, where a 10-foot head is utilized, developing about 450 horsepower. There are five possible storage sites on the Des Moines River, as follows: Storm Lake, Buena Vista County; Swan Lake and Turtle Lake, Emmet County; Silver Lake and Medium Lake, Palo Alto County. 
Devils Creek (L); Greene County; rises in T. 85 N., R. 29 W.; flows southeast $5 \frac{1}{2}$ miles into East Buttrick Creek in Greene County, T. 85 N., R. 29 W.

Devils Creek (R); Lee County; rises in T. 69 N., R. 7 W.; flows southeast 21 miles into Mississippi River in Lee County, T. 67 N., R. $5 \mathrm{~W}$.

Devils Creek, Little (L);. Lee County; rises in sec. 12, T. 68 N., R. 5 W.; flows south 8 miles into Devils Creek (tributary to the Mississippi) in Lee County, sec. 15, T. 67 N., R. 5 W.

Devils Run (L); Iowa County; rises in sec. 2, T. 79 N., R. 12 W.; flows southeast 6 miles into North English River (tributary through English River to Iowa River and thus to the Mississippi) in sec. 4, T. 78 N., R. 11 W.

Dick Creek (R); Wayne County; rises in T. 69 N., R. 23 W.; flows east 5 miles into South Fork of Chariton River (tributary through Chariton River to the Missouri) in Wayne County, T. 69 N., R. 22 W.

Dickson Branch $(\mathrm{R})$; Carroll County; rises in sec. 32 , T. 85 N., R. 33 W.; flows southeast and northeast 5 miles into Raccoon River (tributary through Des Moines River to the Mississippi).

Doe Branch (R); Carroll County; rises in sec. 17, T. 84 N., R. 33 W.; flows southeast and northeast 6 miles into Raccoon River (tributary through Des Moines River to the Mississippi).

Doe Creek (R); Clayton County; rises in T. 91 N., R. 5 W.; flows northeast 5 miles into Volga River (tributary through Turkey River to the Mississippi) in Clayton County, T. 92 N., R. 4 W.

$\operatorname{Dog}$ Creek (R); O'Brien County; rises in sec. 24, T. 94 N., R. 40 W.; flows 6 miles into Little Sioux River (tributary to the Missouri) in sec. 34, T. 94 N., R. 39 W.

Dolhee Creek (R); Des Moines County; rises in sec. 29, T. 72 N., R. 3 W.; flows northeast 5 miles into Mississippi River.

Dowd Creek (L); Grundy County; rises in sec. 17, T. 87 N., R. 18 W.; flows south 6 miles and southwest 6 miles into Iowa River (tributary to the Mississippi) in Marshall County, T. 85 N., R. 19 W.

Dry Creek $(\mathrm{R})$; Benton County; rises in T. 83 N., R. 9 W.; flows northeast 11 miles into Cedar River (tributary through Iowa River to the Mississippi) in Linn County, T. 84 N., R. 8 W.

Dry Creek (L); Buchanan County; rises in T. 88 N., R. 7 W.; flows south 9 miles into Wapsipinicon River (tributary to the Mississippi) in Buchanan County, T. 87 N., R. 7 W. Total fall, about 180 feet.

Dry Creek $(\mathrm{R})$; Linn County; rises in sec. 12, T. 85 N., R. 7 W.; flows southwest 11 miles and east 4 miles into Indian Creek (tributary through Cedar River to Iowa River, which discharges into the Mississippi) in T. 84 N., R. 7 W.

Dry Creek (L); Sioux County; rises in T. 96 N., R. 46 W.; flows southwest 19 miles into Big Sioux River (tributary to the Missouri) at Hawarden, Sioux County, T. 93 N., R. 48 W.

Dry Creek (L); Story County; rises in sec. 3, T. 84 N., R. 23 W.; flows northwest 2 miles into Bear Creek (tributary through Skunk River to the Mississippi).

Dry Mill Creek (L); Clayton County; rises in T. 93 N., R. 4 W.; formed by two small branches; flows 7 miles generally southwest into Roberts Creek in T. 93 N., R. $5 \mathrm{~W}$.

Dry Run (R); Blackhawk County; rises in sec. 32, T. 89 N., R. 14 W.; flows northeast 6 miles into Cedar River (tributary through Iowa River to the Mississippi).

Dry Run (L); Butler County; rises in sec. 33, T. 92 N., R. 16 W.; flows southeast 10 miles into West Fork of Cedar River (tributary through Cedar River to Iowa River and thus to the Mississippi) in Butler County, sec. 4, T. 90 N., R. 15 W.

Dry Run (L); Osceola County; rises in sec. 32, T. 100 N., R. 39 W.; flows south 6 miles into Ocheydan River (tributary through Little Sioux River to Missouri River) 2 miles northeast of May City. 
Dry Run (R); Winneshiek County; rises in T. 98 N., R. 9 W.; flows southeast and northeast 9 miles into Upper Iowa River (tributary to the Mississippi) in sec. 15, T. 98 N., R. 8 W.

Duck Creek (R); Jackson County; rises in sec. 34, T. 86 N., R. 4 E.; flows northeast 5 miles into Mississippi River.

Duck Creek (R); Scott County; rises in T. 78 N., R. 2 E.; flows east 18 miles into Mississippi River in Scott County, T. 78 N., R. 4 E.

Dug Out Creek (R); Osceola County; rises in T. 99 N., R. 39 W.; flows east 7 miles into Little Sioux River (tributary to the Missouri) in Dickinson County, sec. 1 , T. 99 N., R. 38 W.

Dutch Creek (L); Washington County; rises in sec. 30, T. 76 N., R. 9 W.; flows south 10 miles into Skunk River (tributary to the Mississippi) in sec. $8, T$. 74 N., R. $9 \mathrm{~W}$.

Dye Branch Creek (L); Story County; rises in sec. 7, T. 84 N., R. 21 W.; flows south 5 miles and southwest $4 \frac{1}{4}$ miles into East Indian Creek (tributary through Indian Creek to Skunk River and thus to the Mississippi) in Story County, sec. 14, T. 83 N., R. $22 \mathrm{~W}$.

Eagle Creek (L); Wright County; rises in T. 93 N., R. 25 W.; flows southwest 9 miles and south $20 \frac{1}{2}$ miles into Boone River (tributary through Des Moines River to the Mississippi) in Hamilton County, T. 89 N., R. 25 W.

Eagle Creek, Little (L); Wright County; rises in sec. 1, T. 92 N., R. 25 W.; flows southwest $7 \frac{1}{2}$ miles into Eagle Creek (tributary through Boone River to Des Moines River and thus to the Mississippi) in Wright County, sec. 4, T. 91 N., R. 25 W.

East. (See significant name.)

East Branch. (See significant name.)

East Fork. (See significant name.)

Elk Creek $(\mathrm{R})$; Clinton County; rises in T. 83 N., R. 5 E.; flows southeast 5 miles and east 7 miles into Mississippi River in Clinton County, sec. 20, T. 83 N., R. 7 E.

Elk Creek (R); Delaware County; rises at altitude 1,040 feet above sea level in T. 90 N., R. 4 W.; flows north 13 miles into Turkey River (tributary to the Mississippi) in Clayton County, T. 92 N., R. 4 W., at altitude 650 feet above sea level. Water power is developed at Greely, where a 30 -foot head creates 10 horsepower, and at Almont, where a 20 -foot head creates 50 horsepower.

Elk Creek (R); Harrison County; rises in sec. 7, T. 81 N., R. 42 W.; flows southwest $6 \frac{1}{2}$ miles into Willow Creek (tributary through Boyer River to the Missouri) in Harrison County, sec. 11, T. 80 N., R. 43 W.

Elk Creek (L); Jasper County; rises in sec. 25, T. 80 N., R. 19 W.; flows southeast 23 miles into South Skunk River (tributary through Skunk River to the Mississippi) in Mahaska County, T. 77 N., R. 17 W.

Elk Creek (L); Saç County; rises in T. 88 N., R. 38 W.; flows southwest 12 miles into Maple River (tributary through Little Sioux River to the Missouri) in Ida County, T. 87 N., R. 40 W.

Elk Creek (R); Worth County; rises in T. 100 N., R. 22 W.; flows southeast $17 \frac{1}{2}$ miles into Shellrock River (tributary through Cedar River to Iowa River and thus to the Mississippi) in T. 99 N., R. 20 W.

Elk Creek, Little (L); Jasper County; rises in sec. 1, T. 78 N., R. 18 W.; flows south 5 miles into Elk Creek (tributary through South Skunk River to Skunk River and thus to the Mississippi) in sec. 25, T. 78 N., R. 18 W.

Elk Run (L); Blackhawk County; rises in sec. 27, T. 90 N., R. 12 W.; flows south 10 miles into Cedar River (tributary through Iowa River to the Mississippi) in sec. 6 , T. 88 N., R. 12 W.

Elk Run River (R); Carroll County; rises in secs. 6 and 7, T. 85 N., R. 34 W.; flows east 7 miles into Raccoon River (tributary through Des Moines River to the Mississippi) in sec. 7, T. 85 N., R. $33 \mathrm{~W}$. 
Elkhorn Creek, Little (R); Cedar County; rises in T. 79 N., R. 1 W.; flows south 7 miles into Mud Creek (tributary through Sugar Creek to Cedar River, which discharges into the Mississippi through Iowa River) in Muscatine County, T. 78 N., R. $1 \mathrm{~W}$.

Ell Creek (R); Iowa County; rises in sec. 16, T. 80 N., R. 11 W.; flows northwest 2 miles into Little Bear Creek (tributary through Bear Creek to Iowa River and thus to the Mississippi).

Elliott Creek (L); Plymouth County; rises in T. 90 N., R. 45 W.; flows south $19 \frac{1}{2}$ miles into Whiskey Creek (tributary through West Fork of Little Sioux River to Little Sioux River and thus to the Missouri) in Woodbury County, T. 88 N., R. $45 \mathrm{~W}$.

Ellsworth Creek (L); Blackhawk County; rises in sec. 19, T. 90 N., R. 12 W.; flows south 6 miles into Cedar River (tributary through Iowa River to the Mississippi) at Waterloo, T. 89 N., R. 13 W.

Elm Creek (L); Shelby County; rises in T. 80 N., R. 37 W.; flows southwest $6 \frac{1}{2}$ miles into East Nishnabotna River (tributary through Nishnabotna River to the Missouri) in Shelby County, T. 79 N., R. 38 W.

English Creek (R); Lucas County; rises in T. 72 N., R. 21 W.; flows north $7 \frac{1}{2}$ miles and northeast $23 \frac{1}{2}$ miles into Des Moines River (tributary to the Mississippi) in Marion County, T. 75 N., R. 18 W.

English River (R); formed by the junction of North, Middle, and South forks. in Washington County, T. 78 N., R. 10 W., and T. 77 N., R. 9 W. (South Fork); flows east 23 miles into Iowa River (tributary to the Mississippi) in T. 77 N., R. $6 \mathrm{~W}$. Water power is developed at Riverside, where an unknown head creates 40 horsepower, and at Wellman, where a 6 -foot head creates 50 horsepower.

English River, Middle Fork (R); Poweshiek County; rises in T. 78 N., R. 13 W.; flows southeast $17 \frac{1}{2}$ miles into English River (tributary through Iowa River to the Mississippi) in Iowa County, T. 78 N., R. 10 W.

English River, North Fork (L); Poweshiek County; rises in T. 80 N., R. 16 W.; flows southeast $42 \frac{1}{2}$ miles into English River (tributary through Iowa River to the Mississippi) in junction with Middle Fork in Iowa County, T. 78 N., R. 10 W.

English River, South Fork (R); Poweshiek County; rises in T. 78 N., R. 14 W.; flows southeast $36 \frac{1}{2}$ miles into English River (tributary through Iowa River to the Mississippi) in Washington County, T. 77 N., R. 9 W.

Eversole Creek (R); Boone County; rises in sec. 18, T. 82 N., R. 26 W.; flows southeast 4 miles into Des Moines River (tributary to the Mississippi) in Boone County, sec. 27, T. 82 N., R. 26 W.

Fabius Creek (L); Appanoose County; rises in T. 68 N., R. 16 W.; flows southeast 14 miles through Davis County into the State of Missouri, T. 67 N., R. 14 W.

Farm Creek (L); Pottawattamie County; rises in sec. 25, T. 75 N., R. 39 W.; flows southwest 9 miles into Jordan Creek (tributary through Graybill Creek to Nishnabotna River and thus to the Missouri) in Pottawattamie County, sec. 31, T. 74 N., R. $39 \mathrm{~W}$.

Farmers Creek (L); Jackson County; rises in T. 87 N., R. 3 E.; flows south 14 miles into North Fork of Maquoketa River (tributary through Maquoketa River to the Mississippi) in Jackson County, T. 85 N., R. 3 E.

Fiddle Creek (South Creek) (R); Cherokee County; rises in sec. 9, T. 92 N., R. 42 W.; flows south 12 miles into West Fork of Little Sioux River (tributary through Little Sioux River to the Missouri) in Cherokee County, sec. 31, T. 91 N., R. $42 \mathrm{~W}$.

Fisher Creek (L); Page County; rises in T. 69 N., R. 39 W.; flows west 10 miles into East Branch of Nishnabotna River (tributary through Nishnabotna River to the Missouri) in Fremont County, T. 69 N., R. 40 W. 
Fish Lake Creek (R); Harrison County; rises in sec. 30, T. 79 N., R. 44 W.; flows southeast and east 7 miles into Willow Creek (tributary through Boyer River to the Missouri) in Harrison County, sec. 8, T. 78 N., R. 44 W.

Flank Creek (L); Warren County; rises in sec. 19, T. 75 N., R. 22 W.; flows southeast 6 miles into Wolf Creek (tributary through Whitebreast Creek to Des Moines River and thus to the Mississippi) in Warren County, sec. 11, T. 74 N., R. $22 \mathrm{~W}$.

Flint River (R); Henry County; rises in T. 71 N., R. 5 W.; flows southeast 20 miles into Mississippi River at Burlington, Des Moines County, T. 70 N., R. 2 W.

Flint River, Little (R); Des Moines County; rises in T. 70 N., R. 4 W.; flows northeast 5 miles into Flint River (tributary to the Mississippi) in Des Moines County, sec. 16, T. 70 N., R. 3 W.

Flood or Floyd Creek (L); Floyd County; rises in T. 97 N., R. 18 W.; flows southeast $33 \frac{1}{2}$ miles into Shellrock River (tributary through Cedar River to Iowa River and thus to the Mississippi) in Butler County, T. 93 N., R. 16 W.

Floyd River (L); O'Brien County; rises in T. 97 N., R. 41 W.; flows northwest 15 miles, west 5 miles, and southwest 68 miles into Missouri River at Sioux City.

Floyd River, Little (R); O'Brien County; rises in sec. 35, T. 97 N., R. 41 W.; flows west 12 miles into Floyd River (tributary to the Missouri) in Sioux County, T. 96 N., R. 43 W.

Floyd River, West Branch (R); Sioux County; rises in T. 97 N., R. 44 W.; flows southwest 18 miles, south 6 miles, and southwest 14 miles into Floyd River (tributary to the Missouri) in Plymouth County, T. 91 N., R. 46 W.

Fly Creek (R); Warren County; rises in sec. 10, T. 75 N., R. 22 W.; flows northeast 7 miles into Coal Creek (tributary to the Mississippi through Des Moines River) in Marion County, T. 76 N., R. 21 W.

Fourmile Creek (L); Boone County; rises in T. 82 N., R. 25 W.; flows southeast 13 miles and south $14 \frac{1}{2}$ miles into Des Moines River (tributary to the Mississippi) in Polk County, T. 78 N., R. 23 W.

Fourmile Creek (R); Cass County; rises in T. 75 N., R. 36 W.; flows west 3 miles and south $2 \frac{1}{2}$ miles into Sevenmile Creek (tributary through West Nodaway River to Nodaway River, which discharges into the Missouri) in Cass County, T. 75 N., R. $36 \mathrm{~W}$.

Fourmile Creek (R); Cherokee County; rises in sec. 30, T. 90 N., R. 40 W.; flows northwest 6 miles into Little Sioux River (tributary to the Missouri) in Cherokee County, sec. 10, T. 90 N., R. 41 W.

Fourmile Creek (R); Cherokee County; rises in sec. 16, T. 93 N., R. 42 W.; flows northeast 8 miles into Mill Creek (tributary through Little Sioux River to the Missouri) in O'Brien County, T. 94 N., R. 41 W.

Fourmile Creek (R); Kossuth County; rises in T. 96 N., R. 30 W.; flows south 13 miles and southeast $4 \frac{1}{2}$ miles into East Des Moines River (tributary through Des Moines River to the Mississippi) in Kossuth County, T. 95 N., R. 29 W.

Fourmile Creek (L); Tama County; rises in sec. 27, T. 86 N., R. 16 W.; flows southeast 9 miles into Wolf Creek (tributary through Cedar River to Iowa River, which discharges into the Mississippi) in Tama County, sec. 7, T. 85 N., R. 14 W.

Fox Creek, North (L); Appanoose County; rises in T. 69 N., R. 16 W.; flows east 9 miles into Fox River (tributary to the Mississippi) in Davis County, T. 69 N., R. $15 \mathrm{~W}$.

Fox Creek, South (R); Appanoose County; rises in T. 68 N., R. 16 W.; flows northeast $8 \frac{1}{2}$ miles into Fox River (tributary to the Mississippi) in Davis County, T. 69 N., R. $15 \mathrm{~W}$.

Fox River (R); Appanoose County; rises in T. 68 N., R. 16 W.; flows northeast 14 miles and southeast 34 miles through Van Buren County into the State of Missouri, T. 67 N., R. 9 W.

Fox River, Little (R); Davis County; rises in T. 68 N., R. 13 W.; flows southeast 15 miles through Van Buren County into the State of Missouri, T. 67 N., R. 10 W. 
French Creek (L); Plymouth County; rises in sec. 17, T. 91 N., R. 48 W.; flows southwest 4 miles into Big Sioux River (tributary to the Missouri).

Fudge Creek (L); Mahaska County; rises in sec. 27, T. 74 N., R. 15 W.; flows southwest 6 miles into Des Moines River (tributary to the Mississippi) in Wapello County, sec. 23, T. 23 N., R. 15 W.

Fullington Creek (L); Jasper County; rises in sec. 4, T. 80 N., R. 20 W.; flows southwest 5 miles into Skunk River (tributary to the Mississippi).

Gard Creek (L); Monona County; rises in sec. 2, T. 84 N., R. 43 W.; flows southwest 4 miles into Little Sioux River (tributary to the Missouri) in T. 84 N., R. 44 W.

German Creek (L); Keokuk County; rises in T. 77 N., R. 11 W.; flows south $12 \frac{1}{2}$ miles into North Skunk River (tributary through Skunk River to the Mississippi) in Keokuk County, sec. 21, T. 75 N., R. 11 W.

Glynn Branch (R); Scott County; rises in sec. 35, T. 80 N., R. 4 E.; flows northeast 8 miles into Wapsipinicon River (tributary to the Mississippi).

Goddard Creek (L); Winnebago County; rises in sec. 18, T. 96 N., R. 10 W.; flows south 2 miles into Little Turkey River (tributary to the Mississippi).

Goose Creek (R); rises in Freeborn County, Minn.; enters Worth County in T. 100 N., R. 21 W.; flows southeast 3 miles into Shellrock River (tributary through Cedar River to Iowa River and thus to the Mississippi) in Worth County, sec. 18, T. 100 N., R. 20 W.

Goose Creek (R); Washington County; rises in T. 76 N., R. 7 W.; flows east 10 miles into Iowa River (tributary to the Mississippi) in Louisa County, T. 76 N., R. 5 W.

Grand River (R); Adair County; rises in T. 76 N., R. 31 W.; flows southeast 82 miles through Decatur County into the State of Missouri, T. 67 N., R. 26 W. Water power is developed at Davis City, where a 6-foot head creates 50 horsepower.

Grand River, East Fork (L); Union County; rises in T. 71 N., R. 29 W.; flows south 26 miles and southwest 6 miles through Ringgold County into the State of Missouri, T. 67 N., R. 29 W.

Grand River, West Fork (R); Union County; rises in T. 72 N., R. 30 W.; flows southwest $38 \frac{1}{2}$ miles through Ringgold County into the State of Missouri, T. 67 N., R. $31 \mathrm{~W}$.

Granger Creek (R); Dubuque County; rises in sec. 22, T. 88 N., R. 3 E.; flows northeast 5 miles into North Fork of Catfish River (tributary to the Mississippi) in T. 88 N., R. 4 E.

Graybill Creek (L); Pottawattamie County; rises in T. 77 N., R. 38 W.; flows southwest 26 miles into West Nishnabotna River (tributary through Nishnabotna River to the Missouri) in Mills County, T. 73 N., R. 40 W.

Grays Creek (R); Monroe County; rises in sec. 33, T. 73 N., R. 17 W.; flows east 10 miles into Des Moines River (tributary to the Mississippi) in Monroe County, T. 73 N., R. 16 W.

Gritter Creek (R); Iowa County; rises in T. 78 N., R. 12 W.; flows east $10 \frac{1}{2}$ miles into Middle English River (tributary through English River to Iowa River and thus to the Mississippi) in Iowa County, T. 78 N., R. 11 W.

Grove Creek (L); Harrison County; rises in sec. 26, T. 79 N., R. 42 W.; flows west and northwest $7 \frac{1}{2}$ miles into Boyer River (tributary to Missouri River) in Harrison County, sec. 35 , T. 79 N., R. 42 W.

Hall Creek (L); Monona County; rises in sec. 35, T. 82 N., R. 43 W.; flows west 5 miles into Soldier River (tributary to the Missouri) in Monona County, sec. 30, T. 82 N., R. 43 W.

Hall Run (R); Decatur County; rises in sec. 30, T. 70 N., R. 27 W.; flows south 14 miles into Grand River (tributary to the Missouri) in Decatur County, sec. 18, T. 68 N., R. $26 \mathrm{~W}$.

Hammers Creek (R); Grundy County; rises in T. 89 N., R. 15 W.; flows northeast $5 \frac{1}{2}$ miles into Beaver Creek (tributary through Cedar River to Iowa River and thus to the Mississippi) in Butler County, T. 90 N., R. 15 W. 
Hardin Creek (L); Webster County; rises in T. 87 N., R. 30 W.; flows south 26 miles and southeast 10 miles into Raccoon River (tributary through Des Moines River to the Mississippi) in Greene County, T. 83 N., R. 30 W.

Harrington Creek (L); Dubuque County; rises in sec. 9, T. 90 N., R 2 E.; flows southwest 3 miles into North Fork of Maquoketa River (tributary through Maquoketa River to the Mississippi).

Harter Creek (L); Buchanan County; rises in sec. 2, T. 89 N., R. 9 W.; flows southwest 6 miles into Wapsipinicon River (tributary to the Mississippi).

Hartgrave Creek $(\mathrm{R})$; formed by the junction of Otter and Squaw creeks in Franklin County, T. 92 N., R. 19 W.; flows southeast 16 miles into West Fork of Cedar River (tributary through Cedar River to Iowa River, which discharges into the Mississippi) in Butler County, T. 91 N., R. 18 W.

Harts Mill Creek (R); Clinton County; rises in sec. 1, T. 81 N., R. 5 E.; flows southeast 7 miles into Mississippi River in T. 81 N., R. 6 E.

Haskins Creek (L); Ida County; rises in T. 86 N., R. 39 W.; flows northwest 5 miles into Odebolt Creek (tributary through Maple River to Little Sioux River and thus to the Missouri) in T. 87 N., R. 39 W.

Hawk Creek (R); Woodbury County; rises in sec. 6, T. 86 N., R. 42 W.; flows southwest 4 miles into Reynolds Creek (tributary through Maple River to Little Sioux River, which discharges into the Missouri).

Henry Creek (R); O'Brien County; rises in sec. 36, T. 95 N., R. 39 W.; flows south 5 miles into Little Sioux River (tributary to the Missouri) in sec. 24, T. 94 N., R. $39 \mathrm{~W}$.

Herster Creek (L); Monona County; rises in T. 85 N., R. 42 W.; flows northwest 4 miles into Maple River (tributary through Little Sioux River to the Missouri) in T. 85 N., R. 43 W.

Hewett Creek (R); 7 miles long; rises in Clayton County and flows in .a northeasterly direction into Volga River (tributary through Turkey River to the Mississippi).

Hickory Creek (L); Appanoose County; rises in T. 68 N., R. 18 W.; flows northeast 5 miles into Copper Creek (tributary through Chariton River to the Missouri) in T. 68 N., R. 17 W.

High Creek (L); Fremont County; rises in sec. 17, T. 67 N., R. 40 W.; flows southwest 4 miles into the State of Missouri through sec. 31, T. 67 N., R. 40 W.

Hillton Creek (R); Iowa County; rises in sec. 20, T. 80 N., R. 10 W.; flows north 6 miles into Iowa River (tributary to the Mississippi) in sec. 28, T. 81 N., R. 10 W.

Hine Creek (L); Kossuth County; rises in sec. 1, T. 94 N., R. 30 W.; flows south $6 \frac{1}{2}$ miles into Lotts Creek (tributary through East Des Moines River to Des Moines River, which discharges into the Mississippi) in sec. 32, T. 94 N., R. 29 W.

Hinkle Creek (R); Benton County; rises in T. 85 N., R. 11 W.; flows northeast 8 miles into Cedar River (tributary to the Mississippi) at Vinton, sec. 17, T. 85 N., R. $10 \mathrm{~W}$.

Hinton Creek (L); Monroe County; rises in sec. 6, T. 71 N.; R. 17 W.; flows northeast 2 miles into Coal Creek (tributary through Cedar Creek to Des Moines River and thus to the Mississippi) in sec. 33 , T. 72 N., R. 17 W.

Hog Run (R); Iowa County; rises in sec. 9, T. 79 N., R. 11 W.; flows northeast 6 miles into Old Mans Creek (tributary through Iowa River to the Mississippi) in sec. 6 , T. 79 N., R. $10 \mathrm{~W}$.

Holaday Creek (L); Webster County; rises in sec. 36, T. 90 N., R. 28 W.; flows south 9 miles into Des Moines River (tributary to the Mississippi) in sec. 15, T. 88 N., R. 28 W.

Honey Creek $(\mathrm{R})$; formed by the union of two small streams in Clayton County, T. 91 N., R. 5 W.; flows northeast 5 miles into Volga River (tributary through Turkey River to the Mississippi) in T. 92 N., R. 4 W. 
Honey Creek (L); Delaware County; rises in T. 90 N., R. 5 W.; flows southwest 12 miles into Maquoketa River (tributary to the Mississippi) in Delaware County, T. 89 N., R. 5 W. Total fall, about 240 feet. Water power is developed at Manchester, where a 9 -foot head creates 25 horsepower.

Honey Creek (L); Fremont County; rises in sec. 4, T. 70 N., R. 40 W.; flows southwest 8 miles into West Nishnabotna River (tributary through Nishnabotna River to the Missouri) in sec. 8, T. 69 N., R. 41 W.

Honey Creek (R); Hardin County; rises in T. 87 N., R. 22 W.; flows southeast 29 miles into Iowa River (tributary to the Mississippi) in Marshall County, T. 85 N., R. $19 \mathrm{~W}$.

Honey Creek (L); Harrison County; rises in T. 78 N., R. 43 W.; flows southwest $14 \frac{1}{2}$ miles into Boyer River (tributary to the Missouri) in Pottawattamie County, sec. 4 , T. 76 N., R. $44 \mathrm{~W}$.

Honey Creek (R); Iowa County; rises in sec. 31, T. 81 N., R. 12 W.; flows northeast 7 miles into Iowa River (tributary to the Mississippi) in Iowa County, sec. 12 , T. 81 N., R. 12 W.

Honey Creek (L); Monroe County; rises in T. 71 N., R. 19 W.; flows southeast 8 miles into Chariton River (tributary to the Missouri) in Appanoose County, T. 70 N., R. $18 \mathrm{~W}$.

Honey Creek (L); Muscatine County; rises in T. 77 N., R. 4 W.; flows south $7 \frac{1}{2}$ miles into Iowa River (tributary to the Mississippi) in Louisa County, T. 75 N., R. $5 \mathrm{~W}$.

Honey Creek (R); Taylor County; rises in T. 69 N., R. 32 W.; flows southwest 17 miles and south 6 miles through Taylor County into the State of Missouri, T. 67 N., R. $33 \mathrm{~W}$.

Honey Creek (R); Wapello County; rises in sec. 33, T. 72 N., R. 12 W.; flows northeast 7 miles into West Competine Creek (tributary through Cedar Creek to Skunk River and thus to the Mississippi) in sec. 31 , T. 72 N., R. 11 W.

Hoosier Creek (L); Linn County; rises in T. 82 N., R. 7 W.; flows southeast 8 miles into Iowa River (tributary to the Mississippi) in Johnson County, T. 81 N., R. 6 W.

Howerton Branch (R); Madison County; rises in T. 76 N., R. 29 W.; flows east 8 miles into North River (tributary through Des Moines River to the Mississippi) in Madison County, T. 76 N., R. 28 W.

Huffman Creek (R); Harrison County; rises in sec. 34, T. 81 N., R. 43 W.; flows south 6 miles into Willow Creek (tributary through Boyer River to the Missouri) in T. 80 N., R. $43 \mathrm{~W}$.

Hunter Branch (Walnut Creek) (R); Mills County; rises in T. 71 N., R. 40 W.; flows 11 miles into Walnut Creek (tributary through West Nishnabotna River to Nishnabotna River and thus to the Missouri) in Fremont County, sec. 5, T. 69 N., R. 40 W.

Indian Creek (L); Appanoose County; rises in T. 68 N., R. 16 W.; flows southwest 4 miles into Chariton River (tributary to the Missouri) in Appanoose County, T. 67 N., R. 16 W.

Indian Creek (R); Audubon County; rises in T. 80 N., R. 36 W.; flows southwest 12 miles and south 23 miles into East Nishnabotna River (tributary through Nishnabotna River to the Missouri) in Cass County, T. 75 N., R. 37 W.

Indian Creek (L); Blackhawk County; rises in sec. 29, T. 89 N., R. 11 W.; flows south 8 miles into Cedar River (tributary through Iowa River to the Mississippi) in Blackhawk County, sec. 35, T. 88 N., R. 12 W.

Indian Creek (R); Humboldt County; rises in sec. 29, T. 91 N., R. 29 W.; flows east 6 miles into West Des Moines River (tributary through Des Moines River to the Mississippi) in Humboldt County, sec. 24, T. 91 N., R. 29 W. 
Indian Creek (L); Linn County; rises in T. 85 N., R. 6 W.; flows south 6 miles and southwest 10 miles into Cedar River (tributary to the Mississippi) in Linn County, T. 83 N., R. 7 W.

Indian Creek (L); Louisa County; rises in sec. 1, T. 75 N., R. 4 W.; flows southeast $8 \frac{1}{2}$ miles into Iowa River (tributary to the Mississippi) in Louisa County, sec. 7, T. 74 N., R. 3 W.

Indian Creek (L); Pottawattamie County; rises in T. 74 N., R. 38 W.; flows southwest 22 miles into West Nishnabotna River (tributary through Nishnabotna River to the Missouri) in Mills County, T. 72 N., R. 41 W.

Indian Creek (R); Pottawattamie County; rises in sec. 28, T. 76 N., R. 43 W.; flows southwest 10 miles into Missouri River at Council Bluffs, T. 75 N., R. 44 W.

Indian Creek (R); Sac County; rises in T. 89 N., R. 36 W.; flows south 11 miles and northeast 4 miles into Raccoon River (tributary through Des Moines River to the Mississippi) in T. 87 N., R. 36 W.

Indian Creek (L); Sioux County; rises in T. 94 N., R. 46 W.; flows west 3 miles, southwest 9 miles, and west 5 miles into Big Sioux River(tributary to the Missouri) in Plymouth County, T. 93 N., R. 48 W.

Indian Creek $(\mathrm{L})$; formed by the junction of West and East branches of Indian Creek in Story County, T. 82 N., R. 22 W.; flows southeast $20 \frac{1}{2}$ miles into Skunk River (tributary to the Mississippi) in Jasper County, T. 80 N., R. 21 W.

Indian Creek ( $R$ ); Van Buren County; rises in T. 68 N., R. 11 W.; flows southeast $21 \frac{1}{2}$ miles into Des Moines River (tributary to the Mississippi) in Van Buren County, T. 67 N., R. 8 W.

Indian Creek (L); Warren County; rises in T. 74 N., R. 24 W.; flows east $4 \frac{1}{2}$ miles into Otter Creek (tributary through South River to Des Moines River and thus to the Mississippi) in Warren County, T. 74 N., R. 23 W.

Indian Creek, East Branch (L); Hardin County; rises in T. 86 N., R. 22 W.; flows south 7 miles, southeast 9 miles, and southwest 14 miles into Indian Creek (tributary through Skunk River to the Mississippi) in Story County, T. 82 N., R. 22 W.

Indian Creek, West Branch (R); Story County; rises in T. 84 N., R. 23 W.; flows south 8 miles to Nevada and continues in that direction 7 miles, flowing into Indian Creek (tributary through Skunk River to the Mississippi) in T. 82 N., R. $22 \mathrm{~W}$.

Iowa River (R); formed by junction of West and East branches of Iowa River in Wright County, T. 93 N., R. 23 W.; flows southeast 40 miles to Iowa Falls and continues in that direction 55 miles to a point 2 miles east of Marshalltown, then southeast 19 miles to Tama, southeast 39 miles to Marengo, east 31 miles, southeast 14 miles to Iowa City, and southeast 62 miles into Mississippi River, in Louisa County, T. 73 N., R. 2 W. Gaging station at Marshalltown 1903, Iowa City 1903-1906, Iowa Falls 1911-1913. Water power is developed as follows: At Amana an 8-foot head creates 500 horsepower; at Iowa City an 8-foot head creates 200 horsepower; at Union a $6 \frac{1}{2}$-foot head creates 80 horsepower; at Eldora an 8-foot head creates 70 horsepower; at Iowa Falls a 101 -foot head creates 80 horsepower; at Le Grand a $6 \frac{1}{2}$-foot head creates 90 horsepower; at Alden a 9 -foot head creates 150 horsepower; and at Lime Springs a 9 -foot head creates 35 horsepower.

Iowa River, East Branch (L); Hancock County; rises in T. 97 N., R. 24 W.; flows south 29 miles into Iowa River (tributary to the Mississippi) in junction with West Branch in Wright County, T. 93 N., R. 23 W.

Iowa River, West Branch (R); Hancock County; rises in Crystal Lake, T. 97 N., R. $25 \mathrm{~W}$.; flows southeast 5 miles, south 21 miles, and southeast $18 \frac{1}{2}$ miles into Iowa River (tributary to the Mississippi) in junction with East Branch in Wright County, T. 93 N., R. 23 W. 
Iowa River, South Fork (R); Hardin County; rises in T. 89 N., R. 22 W.; flows south 7 miles and southeast 26 miles into Iowa River (tributary to the Mississippi) in Hardin County, T. 86 N., R. 19 W.

Iowa River, Upper (Oneota River) (R); rises in Iowa drift plain, Mower County, Minn.; flows southeast into Winneshiek County, T. 100 N., R. $10 \mathrm{~W}$; flows south 30 miles to Decorah, thence northeast 38 miles and southeast 8 miles into Mississippi River in Allamakee County, T. 99 N., R. 3 W.

Jack Creek (L); Emmet County; rises in Swan Lake in T. 99 N., R. 32 W.; flows southwest 15 miles and south 4 miles into West Des Moines River (tributary through Des Moines River to the Mississippi) in Palo Alto County, T. 97 N., R. $33 \mathrm{~W}$.

Jack Creek (R); Lee County; rises in sec. 23, T. 67 N., R. 6 W.; flows southeast 7 miles into Mississippi River in Lee County, sec. 10, T. 66 N., R. 5 W.

Jackson Creek (R); Wayne County; rises in sec. 35, T. 69 N., R. 22 W.; flows east 8 miles and north 4 miles into South Chariton River (tributary through Chariton River to the Missouri) in Wayne County, sec. 1, T. 69 N., R. 21 W.

John Creek (R); Dubuque County; rises in T. 88 N., R. 1 W.; flows southwest 9 miles into Whitewater Creek (tributary through North Fork of Maquoketa River and thus to the Mississippi) in Dubuque County, T. 87 N., R. 1 E.

Johnson Creek (L); Dallas County; rises in sec. 11, T. 78 N., R. 27 W.; flows southeast 5 miles into Raccoon River (tributary through Des Moines River to the Mississippi) in Dallas County, sec. 34, T. 78 N., R. 26 W.

Johny Creek (L); Louisa County; rises in sec. 5, T. 74 N., R. 4 W.; flows southwest 4 miles into Long Creek (tributary through Iowa River to the Mississippi) in sec. 12 , T. 74 N., R. 5 W.

Jonathan Creek (R); Decatur County; rises in sec. 17, T. 70 N., R. 25 W.; flows southeast 11 miles into Weldon River (tributary through Grand River to the Missouri) in Decatur County, sec. 20, T. 69 N., R. 24 W.

Jones Creek (R); Madison County; rises in T. 75 N., R. 28 W.; flows northeast 10 miles into Clanton Creek (tributary through Middle River to Des Moines River and thus to the Mississippi) in Warren County, T. 75 N., R. 26 W.

Jones Creek (R); Scott County; rises in sec. 33, T. 80 N., R. 4 E.; flows northeast 7 miles into Wapsipinicon River (tributary to the Mississippi).

Jordan Creek (R); Monona County; rises in T. 84 N., R. 43 W.; flows south 13 miles into Soldier River (tributary to the Missouri) in Monona County, T. 82 N., R. 43 W.

Jordan Creek (L); Pottawattamie County; rises in T. 76 N., R. 39 W.; flows southwest 14 miles into Graybill Creek (tributary through West Nishnabotna River to Nishnabotna River and thus to the Missouri) in Pottawattamie County, sec. 36, T. 74 N., R. $40 \mathrm{~W}$.

Jordan Creek $(\mathrm{R})$; Poweshiek County; rises in sec. 32 , T. 79 N., R. 13 W.; flows west 8 miles into North English River (tributary through English River to Iowa River and thus to the Mississippi) in Iowa County, sec. 19, T. 79 N., R. 12 W.

Jordan Creek (L); Wayne County; rises in sec. 29, T. 70 N., R. 21 W.; flows southeast 7 miles into South Fork of Chariton River (tributary through Chariton River to the Missouri) in Wayne County, sec. 1, T. 69 N., R. 21 W.

Keg Creek (L); Shelby County; rises in T. 80 N., R. 39 W.; flows southwest 56 miles to Glenwood, thence southwest 9 miles into Missouri River in Mills County, T. 71 N., R. $43 \mathrm{~W}$.

Keg Creek, Little (R); Pottawattamie County; rises in sec. 33, T. 76 N., R. 42 W. flows $5 \frac{1}{2}$ miles into Keg Creek (tributary to the Missouri) in Pottawattamie County, sec. 27, T. 75 N., R. 42 W.

Keigley's Branch (R); Hamilton County; rises in T. 86 N., R. 24 W.; flows southeast 9 miles into Skunk River (tributary to the Mississippi) in Story County, sec. 7, T. 84 N., R. 23 W. 
Keller Creek (L); Woodbury County; rises in sec. 2, T. 86 N., R. 43 W.; flows north and northwest 5 miles into Miller Creek (tributary through Little Sioux River to the Missouri).

Kidds Creek (L); Shelby County; rises in T. 81 N., R. 38 W.; flows south 5 miles into West Fork of Nishnabotna River (tributary through Nishnabotna River to the Missouri) in Shelby County, T. 80 N., R. 38 W.

Kittson Creek (L); Butler County; rises in T. 92 N., R. 17 W.; flows south 8 miles into West Fork of Cedar River (tributary through Cedar River to Iowa River and thus to the Mississippi) in Butler County, T. 91 N., R. 17 W.

Knapp Creek (L); Benton County; rises in T. 82 N., R. 9 W.; flows southeast $8 \frac{1}{2}$ miles into Iowa River (tributary to the Mississippi) in Johnson County, T. 81 N., R. $8 \mathrm{~W}$., at altitude 700 feet.

Knotty Creek (L); Des Moines County; rises in T. 71 N., R. 3 W.; flows south 7 miles into Flint River (tributary to the Mississippi) in Des Moines County, sec. 24, T. 70 N., R. 3 W.

Koker Creek (R); Woodbury County; rises in T. 87 N., R. 42 W.; flows south $9 \frac{1}{2}$ miles into Maple River (tributary through Little Sioux River to the Missouri) in Woodbury County, T. 86 N., R. 42 W.

Krum Creek (R); Winnebago County; rises in T. 96 N., R. 10 W.; flows northeast 5 miles through Fort Atkinson into Turkey River (tributary to the Mississippi) in sec. 8 , T. 96 N., R. 9 W.

Lake Creek (L); Calhoun County; rises in T. 89 N., R. 32 W.; flows south 21 miles and southwest 11 miles into Raccoon River (tributary through Des Moines River to the Mississippi) in Calhoun County, T. 86 N., R. 34 W.

Lamelee Creek (R); Lee County; rises in sec. 22, T. 66 N., R. 5 W.; flows southeast 4 miles into Mississippi River.

Lick Creek (L); Jefferson County; rises in T. 71 N., R. 11 W.; flows southeast 14 miles into Des Moines River (tributary to the Mississippi) in Van Buren County, T. 69 N., R. $10 \mathrm{~W}$.

I.ick Creek (L); Lee County; rises in T. 68 N., R. 7 W.; flows south 8 miles into Des Moines River (tributary to the Mississippi) in Lee County, sec. 19, T. 67 N., R. $7 \mathrm{~W}$.

Lime Creek (L); Buchanan County; rises in T. 89 N., R. 10 W.; flows south $7 \frac{1}{2}$ miles and southwest 7 miles into Cedar River (tributary through Iowa River to the Mississippi) in Benton County, T. 86 N., R. 10 W. Rises at altitude 980 feet.

Lime Creek (R); Delaware County; rises in T. 87 N., R. 5 W.; flows east 11 miles into Maquoketa River (tributary to the Mississippi) in T. 87 N., R. 4 W. Total fall, about 160 feet.

Lime Creek (R); Freeborn County, Minn.; rises in T. 102 N., R. 23 W.; flows into Winnebago County in T. 100 N., R. 23 W.; flows southwest 17 miles, southeast 11 miles, northeast 6 miles, and southeast 16 miles to Mason City, continuing southeast 15 miles into Shellrock River (tributary through Cedar River to Iowa River and thus to the Mississippi) in Floyd County, T. 95 N., R. 18 W. Water power is developed at Fertile, where a 10 -foot head creates 60 horsepower.

Lindner Creek (L); Hancock County; rises in T. 97 N., R. 26 W.; flows southwest 21 miles into East Des Moines River (tributary through Des Moines River to the Mississippi) in Kossuth County, sec. 8, T. 96 N., R. 28 W.

Lindsey Creek (R); Clayton County; rises in T. 90 N., R. 5 W.; flows southeast and south 10 miles into Honey Creek (tributary through Volga River to Turkey River and thus to the Mississippi) in Delaware County, T. 89 N., R. 5 W. Total fall, about 220 feet.

Iinn Creek (R); Henry County; rises in T. 73 N., R. 6 W.; flows south 7 miles into Big Creek (tributary through Skunk River to the Mississippi) in sec. 29, T. 72 N., R. $6 \mathrm{~W}$. 
Linn Creek (R); Marshall County; rises in sec. 6, T. 83 N., R. 20 W.; flows east 20 miles to Marshalltown, thence 2 miles east into Iowa River (tributary to the Mississippi) in Marshall County, sec. 30, T. 84 N., R. 17 W.

Linn Hollow Creek (L); Woodbury County; rises in sec. 21, T. 86 N., R. 44 W.; flows west 5 miles into Wolf Creek (tributary through West Fork of Little Sioux River to Little Sioux River, which discharges into the Missouri) in sec. 11, T. 86 N., R. 45 W.

Little. (See significant name.)

Little River (R); Decatur County; rises in T. 70 N., R. 25 W.; flows south 14 miles and southeast 9 miles into Missouri through Decatur County, T. 67 N., R. 25 W.

Little River, West (R); Decatur County; rises in sec. 24, T. 70 N., R. 26 W.; flows south $8 \frac{1}{2}$ miles into Little River (tributary to the Missouri) in Decatur County, sec. 31 , T. 69 N., R. 25 W.

Lizard Creek (R); Pocahontas County; rises in T. 93 N., R. 34 W.; flows southeast 51 miles into Des Moines River (tributary to the Mississippi) at Fort Dodge, Webster County, T. 89 N., R. 28 W.

Lizard Creek, North Branch (R); Pocahontas County; rises in T. 93 N., R. 33 W.; flows southeast 24 miles into Lizard Creek (tributary through Des Moines River to the Mississippi) in Pocahontas County, T. 90 N., R. 31 W.

Iizard Creek, South Branch (R); Pocahontas County; rises in T. 91 N., R. 33 W.; flows southeast 33 miles and northeast 4 miles into Lizard Creek (tributary through Des Moines River to the Mississippi) 2 miles west of Fort Dodge in Webster County, T. 89 N., R. 29 W.

Locust Creek (R); Wayne County; rises in sec. 24 , T. 68 N., R. 21 W.; flows southeast 8 miles through sec. 22 , T. 67 N., R. 20 W. into the State of Missouri.

Lone Tree Creek (L); Cass County; rises in T. 76 N., R. 35 W.; flows west 6 miles into Turkey Creek (tributary to the Mississippi) in T. 75 N., R. 36 W.

Lone Tree Creek (R); Linn County; rises in T. 84 N., R. 8 W.; flows northeast 4 miles into Cedar River (tributary through Iowa River to the Mississippi).

Long Branch (R); Guthrie County; rises in sec. 29, T. 78 N., R. 30 W.; flows northeast 6 miles into South Raccoon River (tributary through Raccoon River to Des Moines River and thus to the Mississippi) in Guthrie County, sec. 12, T. 78 N., R. $30 \mathrm{~W}$.

Long Branch (L); Marion County; rises in T. 74 N., R. 21 W.; flows northeast $7 \frac{1}{2}$ miles into English Creek (tributary through Des Moines River to the Mississippi) in Marion County, sec. 17, T. 74 N., R. 20 W.

Long Creek (L); Clarke County; rises in T. 72 N., R. 27 W.; flows $21 \frac{1}{2}$ miles south into Grand River (tributary to the Missouri) in Decatur County, T. 69 N., R. $26 \mathrm{~W}$.

Long Creek (L); Des Moines County; rises in sec. 10, T. 70 N., R. 4 W.; flows south 11 miles into Skunk River (tributary to the Mississippi) in Des Moines County, T. 69 N., R. 3 W.

Long Creek (R); formed in Washington County, T. 75 N., R. 6 W., by the union of North and South forks; flows southeast $32 \frac{1}{2}$ miles into Iowa River (tributary to the Mississippi) in Louisa County, T. 74 N., R. 4 W.

Long Creek, North Branch $(\mathrm{L})$; Washington County; rises in sec. 18, T. 76 N., R. $7 \mathrm{~W}$; flows southeast $14 \frac{1}{2}$ miles into Long Creek (tributary through Iowa River to the Mississippi) in junction with South Branch in Washington County, sec. 26, T. 75 N., R. $6 \mathrm{~W}$.

Long Creek, South Branch (R); Washington County; rises in sec. 26, T. 76 N., R. $8 \mathrm{~W}$.; flows southeast 12 miles into Long Creek (tributary through Iowa River to the Mississippi) in junction with North Branch in sec. 26, T. 75 N., R. 6 W. 
Long Dick Creek (L); Hamilton County; rises in sec. 8, T. 87 N., R. 23 W.; flows south 18 miles into Skunk River (tributary to the Mississippi) in Story County, T. 85 N., R. $23 \mathrm{~W}$.

Lost Creek (R); Lee County; rises in T. 69 N., R. 5 W.; flows southeast 18 miles into Mississippi River in Lee County, T. 68 N., R. 3 W.

Lost Creek (L); Mahaska County; rises in sec. 3, T. 77 N., R. 14 W.; flows southwest 6 miles into North Skunk River (tributary through Skunk River to the Mississippi) in sec. $76 \mathrm{~N} .$, R. $14 \mathrm{~W}$.

Lost Creek (L); Mahaska County; rises in sec. 21, T. 74 N., R. 15 W.; flows southwest 4 miles into Muchakinok Creek (tributary through Des Moines River to the Mississippi).

Lost Creek (R); Scott County; rises in sec. 17, T. 79 N., R. 4 E.; flows northeast 15 miles into Wapsipinicon River (tributary to the Mississippi) in T. 80 N., R. $5 \mathrm{E}$.

Lotts Creek (R); Kossuth County; rises in T. 97 N., R. 30 W.; flows south 18 miles and southeast 18 miles into East Des Moines River (tributary through Des Moines River to the Mississippi) in Humboldt County, T. 93 N., R. 28 W.

Lotts Creek (L); Ringgold County; rises in T. 70 N., R. 28 W.; flows south 20 miles through Ringgold County into the State of Missouri, T. 67 N., R. 29 W.

Lutes Creek (R); Jasper County; rises in T. 81 N., R. 17 W.; flows north 7 miles into Timber Creek (tributary through Iowa River to the Mississippi) in Marshall County, sec. 6, T. 82 N., R. 17 W.

Lyons Creek (L); Hamilton County; rises in sec. 8, T. 89 N., R. 24 W., flows southwest 7 miles into Boone River (tributary through Des Moines River to the Mississippi) at Webster City, Hamilton County, T. 88 N., R. 25 W.

Lytle Creek (L); Dubuque County; rises in T. 88 N., R. 3 E.; flows southwest 7 miles and south 12 miles into North Fork of Maquoketa River (tributary through Maquoketa River to the Mississippi) in Jackson County, T. 85 N., R. 2 E.

Mad Creek (R); Muscatine County; rises in sec. 1, T. 77 N., R. 2 W.; flows south $5 \frac{1}{2}$ miles into Mississippi River in Muscatine County, T. 77 N., R. 2 W.

Main Creek (R); Lee County; rises in sec. 9, T. 66 N., R. 6 W.; flows southeast 8 miles into Sugar Creek (tributary through Des Moines River to the Mississippi) in Lee County, sec. 6, T. 65 N., R. 5 W.

Mamie Creek (R); Pottawattamie County; rises in sec. 3, T. 75 N., R. 42 W.; flows southwest 3 miles into Keg Creek (tributary to Missouri River).

Manson Branch (R); Appanoose County; rises in T. 68 N., R. 17 W.; flows northwest 3 miles into Copper Creek (tributary through Chariton River to Missouri River).

Maple River (L); Buena Vista-County; rises in T. 92 N., R. 38 W.; flows southwest 12 miles, south 28 miles to Ida Grove and southwest 40 miles into Little Sioux River (tributary to the Missouri) in the central part of T. 83 N., R. 44 W., in Monona County. Water power is developed at Battle Creek, where a 9-foot head creates 90 horsepower. At Ida Grove a 7-foot head creates 35 horsepower and at Danbury a 9 -foot head creates 100 horsepower.

Maquoketa River (R); Fayette County; rises in T. 91 N., R. 8 W.; flows southeast 27 miles to Manchester, continuing in the same direction 24 miles to Monticello, southeast 40 miles, northeast $5 \frac{1}{2}$ miles, southeast 6 miles, and northeast 11 miles into Mississippi River in Jackson County, T. 85 N., R. 5 W. Gaging station at Manchester, 1903. Water power is developed at eight localities. At Pelki a 10 -foot head creates 100 horsepower; at Dundee a 12 -foot head creates 30 horsepower; at Maquoketa a 12 -foot head creates 250 horsepower; at Cascade a 50foot head creates 100 horsepower; at Monticello a $9 \frac{1}{2}$-foot head creates 200 horsepower; at Manchester a 14-foot head creates 300 horsepower and a 9-foot head creates 200 horsepower; at Manchester a 14-foot head creates 120 horsepower; at Hopkinton a 5 -foot head creates 35 horsepower; plants at Clay township, Delaware County, and at Earlville from which no data are available. 
Maquoketa River, Little (R); Dubuque County; rises in T. 89 N., R. 2 W.; flows northeast 20 miles into Mississippi River in T. 90 N., R. 2 E., at elevation 600 feet above sea level.

Maquoketa River, Little, Middle Fork (R); Dubuque County; rises at elevation 1,100 feet above sea level in T. 90 N., R. 1 W.; flows east 10 miles into North Fork of Little Maquoketa River (tributary through Maquoketa River to the Mississippi) in Dubuque County, T. 90 N., R. 1 E.

Maquoketa River, Little, North Fork (L); Dubuque County; rises in T. 90 N., R. $1 \mathrm{~W}$., at elevation 1,120 feet above sea level; flows east 11 miles into Little Maquoketa River (tributary to the Mississippi) in T. 90 N., R. 2 E.; at elevation 680 feet above sea level.

Maquoketa River, North Fork (L); Dubuque County; rises in T. 90 N., R. 1 W.; flows southwest 10 miles, south 16 miles, and southeast $35 \frac{1}{2}$ miles into Maquoketa River (tributary to the Mississippi) 1 mile north of Maquoketa, Jackson County, T. 84 N., R. 2 E.

Marrow Bone Creek (L); Calhoun County; rises in T. 86 N., R. 33 W.; flows south 8 miles into Raccoon River (tributary through Des Moines River to the Mississippi) in Carroll County, T. 85 N., R. 33 W.

Martin Creek (R); Scott County; rises in T. 80 N., R. 4 E.; flows northeast 5 miles into Wapsipinicon River (tributary to the Mississippi) in Scott County, T. 80 N., R. 4 E.

Marvel Creek (L); Adair County; rises in T. 75 N., R. 31 W.; flows east 6 miles and southeast 6 miles into Ninemile Creek in Adair County, T. 74 N., R. 30 W.

Masons Creek (R); Scott County; rises in T. 80 N., R. 3 E.; flows north 6 miles into Wapsipinicon River (tributary to the Mississippi) in Scott County, T. 80 N., R. 3 E.

Maynes Creek (R); Franklin County; rises in T. 92 N., R. 22 W.; flows southeast 10 miles, northeast 12 miles, and east $8 \frac{1}{2}$ miles into West Fork of Shellrock River (tributary through Shellrock River to Cedar River, which discharges into the Mississippi through Iowa River) in Butler County, T. 91 N., R. 17 W.

McGruder Creek (L); Decatur County; rises in T. 69 N., R. 25 W.; flows southwest 9 miles into Little River in T. 68 N., R. 25 W.

McPherron Branch (L); Mills County; rises in T. 71 N., R. 42 W.; flows southwest 5 miles into Wabonsie Creek (tributary to Missouri River) in Fremont County, T. 70 N., R. 43 W.

Meadow Creek (Muddy Creek) (L); Dickinson County; rises in T. 99 N., R. 35 W.; flows southwest 23 miles into Little Sioux River (tributary through Little Sioux River to the Missouri) in Clay County, 5 miles below Spencer, T. 96 N., R. $36 \mathrm{~W}$.

Meadow Creek, West Branch (R); Clay County; rises in sec. 3, T. 97 N., R. 36 W.; flows south 6 miles into Meadow Creek (tributary through Little Sioux to the Missouri) in Clay County, sec. 3, T. 96 N., R. 36 W.

Medicine River, Big Fork (R); Wayne County; rises in sec. 10, T. 68 N., R. 21 W.; flows south 9 miles through Wayne County into Putnam County, Mo., sec. 24, T. 67 N., R. 22 W.

Medicine River, Middle Fork (R); Wayne County; rises in sec. 16, T. 68 N., R. $22 \mathrm{~W}$.; flows south 6 miles through Wayne County into Big Fork of Medicine River in Putnam County, Mo., T. 67 N., R. 22 W.

Medicine River, West Fork (R); Wayne County; rises in sec. 30, T. 68 N., R. 22 W.; flows southeast 7 miles through Wayne County into Middle Fork of Medicine River in Putnam County, Mo., T. 67 N., R. 22 W.

Mercer Creek (L); Dallas County; rises in sec. 1, T. 78 N., R. 28 W.; flows south 2 miles into Raccoon River (tributary through Des Moines River to the Mississippi).

Mickerson Branch (R); Jackson County; rises in T. 84 N., R. 2 E.; flows northeast 3 miles into South Fork of Maquoketa River (tributary to the Mississippi). 
Middle Creek (R); Mahaska County; rises in T. 77 N., R. 16 W.; flows southeast $20 \frac{1}{2}$ miles into North Skunk River (tributary through Skunk River to the Mississippi) in Mahaska County, T. 76 N., R. 14 W.

Middle Creek (L); Warren County; rises in sec. 8, T. 77 N., R. 25 W.; flows east 9 miles into North River (tributary through Des Moines River to the Mississippi) in Warren County, sec. 10, T. 77 N., R. 24 W.

Middle River (R); Guthrie County; rises in T. 78 N., R. 33 W.; flows southeast 47 miles and northeast 45 miles into Des Moines River (tributary to the Mississippi) in Warren County, T. 77 N., R. 22 W.

Middle. (See also significant name.)

Middle Branch. (See significant name.)

Middle Fork, (See significant name.)

Milk Creek (R); Plymouth County; rises in T. 93 N., R. 46 W.; flows southeast 13 miles into West Floyd River (tributary through Floyd River to the Mississippi) in Plymouth County, T. 92 N., R. 46 W.

Mill Creek (R); Cedar County; rises in T. 82 N., R. 2 W.; flows northeast $9 \frac{1}{2}$ miles into Wapsipinicon River (tributary to the Mississippi) in Jones County, T. 83 N., R. $1 \mathrm{~W}$.

Mill Creek (L); Fremont County; rises in T. 68 N., R. 40 W.; flows southwest 7 miles and northwest 6 miles into Nishnabotna River (tributary to Missouri River) in Fremont County, T. 68 N., R. 41 W.

Mill Creek, Little (R); Jackson County; rises in T. 86 N., R. 4 E.; flows northeast 6 miles into Mill Creek (tributary to the Mississippi).

Mill Creek (R); Jackson County; rises in T. 86 N., R. 3 E.; flows southeast 11 miles into Mississippi River.

Mill Creek (R); Monroe County; rises in sec. 16, T. 72 N., R. 10 W.; flows northwest $11 \frac{1}{2}$ miles into Des Moines River (tributary to the Mississippi) in Wapello County, T. 73 N., R. $15 \mathrm{~W}$.

Mill Creek (L); O'Brien County; rises in T. 96 N., R. 40 W.; flows southwest 12 miles and southeast 19 miles into Little Sioux River (tributary to the Missouri) 2 miles above Cherokee in Cherokee County, T. 92 N., R. 40 W.

Miller Creek (L); Woodbury County; rises in T. 87 N., R. 42 W.; flows southwest $8 \frac{3}{4}$ miles into Little Sioux River (tributary to the Missouri) in Woodbury County, T. 86 N., R. $43 \mathrm{~W}$.

Millers Creek (R); Blackhawk County; rises in T. 87 N., R. 13 W.; flows east 11 miles into Cedar River (tributary through Iowa River to the Mississippi) in Blackhawk County, sec. 35 , T. 88 N., R. 12 W.

Mineral Creek (R); Jones County; rises in sec. 6, T. 84 N., R. 2 W.; flows northeast 7 miles and east 9 miles into Maquoketa River (tributary to the Mississippi) in Jackson County, T. 85 N., R. 1 E.

Miners Creek (R); Clayton County; rises in T. 92 N., R. 3 W.; flows southeast 5 miles into Mississippi River in T. 92 N., R. 3 W., at Guttenberg.

Minerva Creek (R); Hardin County; rises in T. 86 N., R. 22 W.; flows southeast $27 \frac{1}{2}$ miles into Iowa River (tributary to the Mississippi) in Marshall County, T. 84 N., R. $19 \mathrm{~W}$.

Minerva Creek, Little (R); Marshall County; rises in T. 84 N., R. 19 W.; flows north $4 \frac{1}{2}$ miles into Minerva Creek (tributary through Iowa River to the Mississippi) in Marshall County, sec. 3, T. 84 N., R. 19 W.

Minerva Creek, South (R); Story County; rises in T. 85 N., R. 22 W.; flows southeast 8 miles and northeast 7 miles into Minerva Creek (tributary through Iowa River to the Mississippi) in Marshall County, sec. 35, T. 85 N., R. 20 W.

Minnehaha Creek (R); Grundy County; rises in T. 87 N., R. 17 W.; flows northeast 5 miles into Blackhawk Creek (tributary through Cedar River to Iowa River and thus to the Mississippi) in Grundy County, T. 87 N., R. 16 W. 
Mississippi River forms the eastern boundary of the State.

Missouri Creek (R); Kossuth County; rises in sec. 27, T. 96 N., R. 27 W.; flows south $8 \frac{1}{2}$ miles into Prairie Creek (tributary through Des Moines River to the Mississippi) in Kossuth County, T. 95 N., R. 27 W.

Missouri River (R); forms part of western boundary along Woodbury, Monona, Harrison, Pottawattamie, Mills, and Fremont counties.

Moffatt Branch (R); Monroe County; rises in sec. 23, T. 71 N., R. 19 W.; flows southeast, northeast, and northwest into Cedar Creek (tributary through Des Moines River to the Mississippi).

Monk Creek (L); Lee County; rises in sec. 23, T. 67 N., R. 7 W.; flows southeast 4 miles into Des Moines River (tributary to the Mississippi).

Montgomery Creek (R); Boone County; rises in sec. 21 , T. 85 N., R. 26 W.; flows southeast 9 miles into Squaw Creek (tributary through Skunk River to the Mississippi) in Boone County, sec. 35, T. 85 N., R. 25 W.

Moody Run (L); a creek 2 miles long which rises in Clayton County and flows in a southeasterly direction into Sny Magill Creek (tributary to the Mississippi).

Moon Creek (L); Poweshiek County; rises in sec. 23, T. 78 N., R. 14 W.; flows southeast and south 11 miles into North Skunk River (tributary through Skunk River to the Mississippi) in Mahaska County, sec. 30, T. 77 N., R. 14 W.

Morgan Creek (R); Benton County; rises in T. 82 N., R. 9 W.; flows southwest 3 miles and northeast 7 miles into Cedar River (tributary through Iowa River to the Mississippi) in Linn County, T. 83 N., R. 8 W.

Mormon Creek (R); Appanoose County; rises in T. 70 N., R. 17 W.; flows northeast 8 miles into Big Soap Creek (tributary through Des Moines River to the Mississippi) in T. 71 N., R. $16 \mathrm{~W}$.

Moser Creek (R); Shelby County; rises in T. 81 N., R. 39 W.; flows southwest $9 \frac{1}{2}$ miles into Mosquito Creek (tributary to Missouri River) in Shelby County, T. 81 N., R. $40 \mathrm{~W}$.

Mosquito Creek (R); Grundy County; rises in T. 87 N., R. 16 W.; flows northeast 8 miles into Blackhawk Creek (tributary to Cedar River, which discharges into the Mississippi through Iowa River) in T. 87 N., R. 15 W.

Mosquito Creek (L); Guthrie County; rises in T. 81 N., R. 31 W.; flows southeast 30 miles into Middle Raccoon River (tributary through Raccoon River to Des Moines River, which discharges into the Mississippi) in Dallas County, T. 79 N., R. 29 W.

Mosquito Creek (L); Shelby County; rises in T. 81 N., R. 39 W.; flows southwest 69 miles into Missouri River in Mills County, T. 73 N., R. 44 W.

Mosquito Creek, Little (L); Pottawattamie County; rises in sec. 7, T. 75 N., R. $42 \mathrm{~W}$.; flows southwest $5 \frac{3}{4}$ miles into Mosquito Creek (tributary to the Missouri) in T. 75 N., R. 43 W.

Muchakinok Creek (L); Mahaska County; rises in sec. 6, T. 76 N., R. 17 W.; flows generally northeast about 28 miles into Des Moines River (tributary to the Mississippi) at Eddyville, sec. 6, T. 73 N., R. 15 W.

Mud Creek (L); Benton County; rises in T. 83 N., R. 10 W.; flows southeast 12 miles into. Prairie Creek (tributary through Cedar River to the Mississippi) at altitude 780 feet in T. 82 N., R. 9 W.

Mud Creek (R); Benton County; rises in T. 84 N., R. 11 W.; flows southeast 4 miles and northeast 9 miles into Cedar River (tributary to the Mississippi) in T. 85 N., R. $10 \mathrm{~W}$.

Mud Creek (R); Cedar County; rises in T. 80 N., R. 1 W.; flows southeast 5 miles and northeast $11 \frac{1}{2}$ miles into Wapsipinicon River (tributary to the Mississippi) in Scott County, T. 80 N., R. 2 E.

Mud Creek (L!; Kossuth County; rises in sec. 34, T. 100 N., R. 30 W.; flows southeast 14 miles and south $7 \frac{1}{2}$ miles into East Des Moines River (tributary through Des Moines River to the Mississippi) in Kossuth County, T. 97 N., R. 29 W.

$77145^{\circ}-15-3$ 
Mud Creek (R); Marshall County; rises in sec. 9, T. 85 N., R. 20 W.; flows southeast $6 \frac{1}{2}$ miles into Honey Creek (tributary through Iowa River to the Mississippi) in Marshall County, sec. 28, T. 85 N., R. 19 W.

Mud Creek (R); rises in Minnesota in T. 102 N., R. 46 W.; enters Iowa in Lyon County (T. 100 N., R. 47 W.); flows south 18 miles into Rock River (tributary through Big Sioux River to the Missouri) 1 mile above mouth of Little Rock River in T. 98 N., R. 46 W.

Mud Creek (L); Muscatine County; rises in T. 78 N., R. 1 E.; flows northwest 7 miles and west 9 miles into Sugar Creek (tributary through Cedar River to Iowa River and thus to the Mississippi) in T. 78 N., R. 2 W.

Mud Creek (R); O'Brien County; rises in sec. 10, T. 94 N., R. 42 W.; flows northeast and southeast 7 miles into Mill Creek (tributary through Little Sioux River to the Missouri) in sec. 17, T. 94 N., R. 41 W.

Mud Creek (L); Polk County; rises in T. 79 N., R. 22 W.; flows south 15 miles into Des Moines River (tributary to the Mississippi) in T. 77 N., R. 22 W.

Mud Creek (R); Plymouth County; rises in sec. 29, T. 90 N., R. 44 W.; flows south 11 miles into West Fork of Little Sioux River (tributary through Little Sioux River to the Missouri) in Woodbury County, sec. 30, T. 89 N., R. 44 W.

Mud Creek (R); Pottawattamie County; rises in T. 75 N., R. 40 W.; flows southwest 9 miles and south 6 miles into West Nishnabotna River (tributary through Nishnabotna River to the Missouri) in Mills County, T. 73 N., R. 41 W.

Muddy Creek. (See Meadow Creek.)

Mumm Creek (L); Lee County; rises in sec. 22, T. 67 N., R. 7 W.; flows southwest 5 miles into Des Moines River (tributary to the Mississippi).

Munns Creek (R); Grundy County; rises in sec. 30, T. 87 N., R. 16 W.; flows northeast 5 miles into Blackhawk Creek (tributary through Cedar River to Iowa River and thus to the Mississippi) in sec. 14, T. 87 N., R. 16 W.

Murray Creek (R); O'Brien County; rises in sec. 1, T. 94 N., R. 40 W.; flows southeast 5 miles into Waterman Creek (tributary through Little Sioux River to the Missouri) in sec. 4, T. 94 N., R. 39 W.

Musketo Creek (L); Muscatine County; rises in sec. 8, T. 77 N., R. 1 W.; flows northwest 7 miles into Cedar River (tributary through Iowa River to the Mississippi) in sec. 29, T. 78 N., R. 2 W.

Musketo Creek, Little(L); Muscatine County; rises in T. 77 N., R. 2 W.; flows south. west $6 \frac{1}{2}$ miles into Cedar River (tributary through Iowa River to the Mississippi) in sec. 35, T. 78 N., R. 3 W.

Nagle Creek (R); 5 miles long; rises in Clayton County and flows in a northeasterly direction into Volga River (tributary through Turkey River to the Mississippi).

Nelson Creek (L); Linn County; rises in T. 85 N., R. 8 W.; flows southwest 4 miles into Cedar River (tributary through Iowa River to the Mississippi).

Nelson Creek (R); O'Brien County; rises in sec. 4, T. 94 N., R. 30 W.; flows southwest 7 miles into Willow Creek in O'Brien County, sec. 25, T. 94 N., R. 41 W.

Ninemile Creek (L); Adair County; rises in T. 76 N., R. 33 W.; flows southwest 8 miles into Middle Nodaway River in Adair County, T. 75 N., R. 33 W.

Nishnabotna River (L); formed by junction of East and West branches in Fremont County, sec. 19, T. 68 N., R. 41 W.; flows south into the State of Missouri (sec. 35, T. 67 N., R. 42 W.). Total length in Iowa, 10 miles. Water power is developed at four localities. At Lewis a 10 -foot head creates 77 horsepower; at Harlan a 7-foot head creates 35 horsepower; at Red Oak an 8-foot head creates 85 horsepower; at Stennett no data are available.

Nishnabotna River, East (L); Carroll County; rises in T. 82 N., R. 35 W.; flows southeast 9 , south 28 , and southwest 48 miles to Red Oak, thence southwest $32 \frac{1}{2}$ miles into Nishnabotna River (tributary to the Missouri) in junction with West Branch in Fremont County, T. 68 N., R. 41 W. 
Nishnabotna River, West (R); Carroll County; rises in T. 83 N., R. 36 W.; flows southwest $125 \frac{1}{2}$ miles into Nishnabotna River (tributary to the Missouri) in junction with East Branch in Fremont County, T. 68 N., R. 41 W. Water power is developed at White Cloud, where a 9-foot head creates 160 horsepower.

Nishnabotna River, West, East Branch (L); Audubon County; rises in T. 81 N., R. $26 \mathrm{~W}$.; flows southwest 36 miles into West Nishnabotna River (tributary through Nishnabotna River to the Missouri) in Pottawattamie County, T. 77 N., R. $39 \mathrm{~W}$.

Nishnabotna River, West, West Branch (R); Crawford County; rises in T. 83 N., R. 37 W.; flows southwest and south 30 miles into West Nishnabotna River (tributary through Nishnabotna River to the Missouri) in Shelby County, T. 79 N., R. 38 W.

Nodaway River (L); formed by the junction of West and Middle Nodaway rivers at Villisca, Montgomery County (T. 71 N., R. 36 W.); flows south 26 miles through Page County (T. 67 N., R. 36 W.) into the State of Missouri. Water power is developed at Shambaugh, where a 9 -foot head creates 40 horsepower.

Nodaway River, East (L); Adams County; rises in T. 74 N., R. 31 W.; flows southwest 25 miles to Corning, southwest 10 miles, south 10 miles, and thence southwest $12 \frac{1}{2}$ miles into Nodaway River in Page County, T. 67 N., R. 36 W. Water power is developed at Hawleyville, where an 8-foot head creates 40 horsepower.

Nodaway River, Middle (L); Adair County; rises in T. 77 N., R. 32 W.; flows southeast 9 miles and southwest 42 miles into Nodaway River at Villisca, Montgomery County, T. 71 N., R. 36 W.

Nodaway River, Middle, East Fork (L); Adair County; rises in T. 77 N., R. 32 W.; flows south 11 miles and southwest 15 miles into Middle Nodaway River in Adair County, T. 74 N., R. 33 W., in junction with West Fork.

Nodaway River, Middle, West Fork (R); Adair County; rises in T. 77 N., R. 33 W.; flows southwest 7 miles, southeast 8 miles, and southwest 8 miles into Middle Nodaway River in Adair County, T. 74 N., R. 33 W., in junction with East Fork.

Nodaway River, West (R); Cass County; rises in T. 76 N., R. 34 W.; flows south 7 miles, southwest 17 miles, and south 18 miles into Nodaway River in junction with East Nodaway River at Villisca, Montgomery County, T. 71 N., R. 36 W.

North River (R); Guthrie County; rises in T. 78 N., R. 31 W.; flows southeast 41 miles and northeast 25 miles into Des Moines River (tributary to the Mississippi) in Polk County, T. 78 N., R. 23 W.

North River, North Branch (L); Madison County; rises in T. 77 N., R. 29 W.; flows southeast 19 miles into North River (tributary through Des Moines River to the Mississippi) in Madison County, T. 77 N., R. 27 W.

North. (See also significant name.)

North Branch. (See significant name.)

North Fork. (See significant name.)

Norway Creek (L); Monona County; rises in sec. 26, T. 83 N., R. 42 W.; flows southwest 6 miles into Soldier River (tributary to the Missouri) in sec. 1, T. 82 N., R. $43 \mathrm{~W}$.

Ocheyedan River (R); rises in Nobles County, Minn. (T. 101 N., R. 41 W.); enters Iowa through Osceola County (T. 100 N., R. 41 W.); flows south 5, southeast 22, south 4, and southeast 13 miles into Little Sioux River (tributary to the Missouri) at Spencer, Clay County, T. 96 N., R. 37 W.

Ocheyedan River, Little (R); Osceola County; rises in T. 99 N., R. 41 W.; flows southeast 20 miles into Ocheyedan River in Osceola County, sec. 28, T. 98 N., R. $39 \mathrm{~W}$.

Odebolt Creek (L); Sac County; rises in T. 87 N., R. 38 W.; flows west $16 \frac{1}{2}$ miles into Maple River (tributary through Little Sioux River to the Missouri) at Ida Grove, Ida County, T. 87 N., R. 40 W. 
Odells Branch (L); rises in Delaware County; a small tributary to Elk Creek in T. 90 N., R. 4 W.

Old Man Creek (R); Iowa County; rises in T. 80 N., R. 12 W.; flows southeast 16, east 20 , and southeast 6 miles into Iowa River (tributary to the Mississippi) in Johnson County, T. 78 N., R. 6 W.

One Hundred and Two River, East Fork (L); Taylor County; rises in T. 70 N., R. $32 \mathrm{~W}$.; flows southwest 24 miles to Bedford and continues southwest 9 miles through Taylor County into the State of Missouri, T. 67 N., R. 34 W.

One Hundred and Two River, Middle Fork (L); Taylor County; rises in T. 69 N., R. 33 W.; flows southwest $23 \frac{1}{2}$ miles through Taylor County into the State of Missouri, T. 67 N., R. $35 \mathrm{~W}$.

One Hundred and Two River, West Fork (R); Adams County; rises in T. 71 N., R. $34 \mathrm{~W}$.; flows south 35 miles through Taylor County into the State of Missouri, T. 67 N., R. $35 \mathrm{~W}$.

Oneota River. (See Iowa River, Upper.)

Opossum Creek (L); Benton County; rises in T. 84 N., R. 10 W.; flows northeast 6 miles and southeast 7 miles into Cedar River (tributary through Iowa River to the Mississippi) in Linn County, T. 84 N., R. 8 W.

Otter Creek (R); Clarke County; rises in T. 72 N., R. 25 W.; flows northeast 11 miles and north $22 \frac{1}{2}$ miles into South River (tributary through Des Moines River to the Mississippi) in Warren County, T. 76 N., R. 23 W.

Otter Creek (L); Fayette County; rises in T. 92 N., R. 9 W.; flows south 9 miles to Oelwein, continues south 5 miles and southeast 8 miles into Wapsipinicon River (tributary to the Mississippi) in Buchanan County, T. 89 N., R. 9 W.

Otter Creek (R); Fayette County; rises in sec. 16, T. 94 N., R. 8 W.; flows east 10 miles into Turkey River (tributary to the Mississippi) in sec. 13, T. 94 N., R. 7 W.

Otter Creek (R); Franklin County; rises in T. 93 N., R. 22 W.; flows southeast 23 miles into Hartgrave Creek (tributary to West Fork of Cedar River, a branch of Cedar River, which discharges into the Mississippi through Iowa River) at its junction with Squaw Creek in T. 91 N., R. 19 W.

Otter Creek (L); Hancock County; rises in T. 96 N., R. 25 W.; flows south 24 miles and southwest 30 miles into Boone River (tributary through Des Moines River to the Mississippi) in Wright County, T. 92 N., R. 26 W.

otter Creek (R); Ida County; rises in T. 86 N., R. 39 W.; flows south $12 \frac{1}{2}$ miles into Boyer River (tributary to the Missouri) in Crawford County, T. 84 N., R. 38 W.

Otter Creek (L); Jackson County; rises in T. 86 N., R. 2 E.; flows southwest 6 miles into Lytles Creek (tributary through Maquoketa River to the Mississippi).

otter Creek (L); Linn County; formed by the junction of East and West branches in T. 84 N., R. 7 W.; flows generally southwest 4 miles into Cedar River (tributary through Iowa River to the Mississippi) in T. 84 N., R. 8 W. Fall from junction to mouth, about 60 feet. The West Branch rises in T. 86 N., R. 8 W., and flows south 10 miles to its junction with East Branch, which rises in T. $85 \mathrm{~N}$., R. $7 \mathrm{~W}$., and flows southwest 9 miles to the junction. Total fall in each branch, about 120 feet.

Otter Creek (L); Louisa County; rises in T. 73 N., R. 4 W.; flows north $5 \frac{1}{2}$ miles and southeast 7 miles into Iowa River (tributary to the Mississippi) in sec. 18, T. 73 N., R. 2 W.

Otter Creek (L); Tama County; rises in sec. 4, T. 83 N., R. 14 W.; flows southeast 12 miles into Iowa River (tributary to the Mississippi) in T. 82 N., R. 13 W.

Otter Creek (L); rises in Minnesota (T. 101 N., R. 41 W.); enters Iowa through Osceola County in T. 100 N., R. 41 W.; flows southwest.7, southeast 5, southwest 12 , west 7 , southwest 2 , and northwest 7 miles into Little Rock River (tributary through Rock River to the Big Sioux and thus to the Missouri) in Lyon County, T. 98 N., R. 43 W. 
Otter Creek, East Branch (R); Linn County; rises in T. 86 N., R. 7 W.; flows south 11 miles into Otter Creek (tributary through Cedar River to Iowa River and thus to the Mississippi) in Linn County, T. 84 N., R. 7 W.

Otter Creek, East Branch (L); Wright County; rises in T. 93 N., R. 25 W.; flows southwest 8 miles into Otter Creek (tributary through Boone River to Des Moines River and thus to the Mississippi) in Wright County, sec. 6, T. 92 N., R. 25 W.

otter Creek, West Branch (L); Linn County; rises in T. 85 N., R. 7 W.; flows southwest 13 miles into Otter Creek (tributary through Cedar River to Iowa River and thus to the Mississippi) in Linn County, T. 84 N., R. 7 W.

Paint Creek (R); Allamakee County; rises in T. 98 N., R. 6 W., 1 miles east of Waukon; flows southeast 20 miles into Mississippi River in T. 96 N., R. 3 W.

Painter Creek (L); Madison County; rises in T. 75 N., R. 26 W.; flows east 7 miles into South River (tributary through Des Moines River to the Mississippi) in Warren County, sec. 24, T. 75 N., R. 25 W.

Palestine Creek (R); Wapello County; rises in sec. 19, T. 73 N., R. 15 W.; flows west 4 miles into Des Moines River (tributary to the Mississippi).

Panther Creek (L); Dallas County; rises in T. 80 N., R. 29 W.; flows southeast 10 and south 7 miles into Raccoon River (tributary through Des Moines River to the Mississippi) in Dallas County, sec. 16, T. 78 N., R. 28 W.

Panther Creek (R); Lee County; rises in sec. 33, T. 68 N., R. 6 W.; flows southeast 6 miles and northeast 4 miles into Devil Creek (tributary through Des Moines River to the Mississippi) in Lee County, sec. 16, T. 67 N., R. 5 W.

Panther Hollow Creek (R); Clayton County; rises in T. 90 N., R. 2 W.; flows northeast about 5 miles into Mississippi River in T. 91 N., R. 1 W. Total fall, about 520 feet.

Pardieu Creek (R); Johnson County; rises in T. 80 N., R. 7 W.; flows southwest $4 \frac{1}{2}$ miles into Iowa River (tributary to the Mississippi) in sec. 33, T. 80 N., R. 6 W.

Parmelly Creek (L); Woodbury County; rises in sec. 15, T. 86 N., R. 43 W.; flows southwest 5 miles into Little Sioux River (tributary to the Missouri) in sec. 25, T. 86 N., R. 44 W.

Pecks Creek (L); Clayton County; rises in sec. 35, T. 91 N., R. 3 W.; flows northeast 5 miles into Turkey River (tributary to the Mississippi) in T. 91 N., R. 3 W. Total fall, 460 feet.

Peese Creek (L); Boone County; rises in sec. 4, T. 83 N., R. 26 W.; flows southwest 4 miles into Des Moines River (tributary to the Mississippi).

Perry Creek (R); Cherokee County; rises in sec. 30, T. 92 N., R. 40 W.; flows south $7 \frac{1}{2}$ miles into Little Sioux River (tributary to the Missouri) in sec. 33, T. 91 N., R. $40 \mathrm{~W}$.

Perry Creek (L); Plymouth County; rises in T. 92 N., R. 47 W.; flows southwest 21 miles into Missouri River at Sioux City, Woodbury County, T. 89 N., R. 47 W.

Peter Creek (L); Floyd County; rises in T. 95 N., R. 16 W.; flows south $5 \frac{1}{2}$ miles into Flood Creek (tributary through Shellrock River to Cedar River, which discharges into the Mississippi through Iowa River) in Floyd County, T. 94 N., R. $16 \mathrm{~W}$.

Picayune Creek (L); Harrison County; rises in sec. 12, T. 80 N., R. 41 W.; flows northwest 4 miles and southwest 4 miles into Boyer River (tributary to the Missouri) in sec. 13, T. 80 N., R. 42 W.

Picayune Creek, North (L); Crawford County; rises in T. 82 N., R. 40 W.; flows southwest 7 miles into Picayune Creek (tributary through Boyer River to the Missouri) in Harrison County, T. 80 N., R. 41 W.

Picayune Creek, South (L); Harrison County; rises in sec. 4, T. 79 N., R. 41 W.; flows northwest 5 miles into Picayune Creek (tributary through Boyer River to the Missouri) in Harrison County, sec. 7, T. 80 N., R. 41 W. 
Pierson Creek (R); Cherokee County; rises in sec. 35, T. 91 N., R. 42 W.; flows south 14 miles into Little Sioux River (tributary to the Missouri) in Woodbury County, T. 89 N., R. $42 \mathrm{~W}$.

Pigeon Creek (R); Appanoose County; rises in T. 67 N., R. 17 W.; flows northeast 4 miles into Chariton River (tributary to the Missouri).

Pigeon Creek (R); Scott County; rises in sec. 2, T. 78 N., R. 5 E.; flows southeast 3 miles into the Mississippi.

Pigeon Creek (L); Shelby County; rises in T. 80 N., R. 40 W.; flows southwest $45 \frac{1}{2}$ miles into Missouri River in Pottawattamie County, T. 76 N., R. 44 W.

Pike Creek (L); Jackson County; rises in T. 85 N., R. 1 E.; flows south 2 miles into South Fork of Maquoketa River (tributary to the Mississippi).

Pike Creek (L); Muscatine County; rises in sec. 4, T. 77 N., R. 3 W.; flows southwest 4 miles into Wapsinonoc Creek (tributary through Cedar River to Iowa River and thus to the Mississippi) in T. 77 N., R. 4 W.

Pike Run (R); Winnebago County; rises in sec. 8, T. 99 N., R. 24 W.; flows southwest 6 miles into Lime Creek (tributary through Shellrock River to Cedar River, which discharges into the Mississippi through Iowa River) in T. 99 N., R. 24 W.

Pilot Creek (R); Palo Alto County; rises in T. 95 N., R. 33 W.; flows southeast 30 miles into West Branch of Des Moines River (tributary through Des Moines River to the Mississippi) in Pocahontas County, T. 93 N., R. 31. W.

Pine Creek (L); Buchanan County; rises in T. 90 N., R. 8 W., at altitude 1,100 feet above sea level; flows southeast $15 \frac{1}{2}$ miles into Wapsipinicon River (tributary to the Mississippi) in Buchanan County, T. 88 N., R. 8 W., ataltitude 880 feet above sea level.

Pine Creek (R); Clayton County; rises in T. 91 N., R. 3 W.; flows west 4 miles into Elk Creek (tributary through Turkey River to the Mississippi) in T. 91 N., R. 4 W.

Pine Creek (L); Grundy County; rises in T. 88 N., R. 18 W.; flows southwest 7 miles into Iowa River (tributary to the Mississippi) in Hardin County, T. 87 N., R. 19 W.

Pine Creek (R); Scott County; rises in T. 78 N., R. 2 E.; flows west 9 miles into Mississippi River in sec. 20, T. 77 N., R. 1 E.

Pine Creek (L); Winneshiek County; rises in sec. 8, T. 100 N., R. 9 W.; flows southeast 8 miles into Upper Iowa River (tributary to the Mississippi) in Winneshiek County, sec. 10, T. 99 N., R. 9 W.

Pine Creek, West Branch (R); Muscatine County; rises in sec. 20, T. 78 N., R. 1 E.; flows southwest and southeast 8 miles into Pine Creek (tributary to the Mississippi) in sec. 17 , T. 77 N., R. 1 E.

Pitcher Creek (L); Buena Vista County; rises in T. 90 N., R. 38 W.; flows southwest 10 miles into Maple River (tributary through Little Sioux River to the Missouri) in Cherokee County, sec. 8, T. 90 N., R. 39 W.

Platte River (L); Adair County; rises in T. 74 N., R. 31 W.; flows south 6, southwest 10, southeast $8 \frac{1}{2}$, south 15 , and southwest 12 miles through Taylor County into the State of Missouri, T. 67 N., R. $32 \mathrm{~W}$.

Pleasant Creek (R); Jackson County; rises in T. 85 N., R. 4 E.; flows east and south 9 miles into Maquoketa River (tributary to the Mississippi) in Jackson County, sec. 32 , T. 85 N., R. 5 E.

Pleasant Run (L); Mahaska County; rises in sec. 31, T. 77 N., R. 14 W.; flows southwest 6 miles into North Skunk River (tributary through Skunk River to the Mississippi) in sec. 4, T. 76 N., R. $14 \mathrm{~W}$.

Plum Creek (L); Delaware County; rises in T. 90 N., R. 4 W., at altitude 1,100 feet above sea level; flows southeast 17 miles and southwest 4 miles into Maquoketa River (tributary to the Mississippi) in T. 87 N., R. 4 W., at altitude 850 feet.

Plum Creek (R); Dubuque County; rises in T. 90 N., R. 1 W.; flows north 4 miles into Mississippi River in Clayton County, T. 91 N., R. 1 W.

Plum Creek (L); Hancock County; rises in T. 97 N., R. 26 W.; flows southwest 19 miles into East Des Moines River (tributary through Des Moines River to the Mississippi) in Kossuth County, sec. 17, T. 96 N., R. 28 W. 
Plum Creek (R); Mills County; rises in T. 71 N., R. 42 W.; flows southwest 11 miles and southeast 6 miles into Willow Slough (tributary through Nishnabotna River to the Missouri) in Fremont County, T. 68 N., R. 43 W.

Plum Creek (R); Union County; rises in T. 71 N., R. 30 W.; flows south 11 miles into West Grand River (tributary to the Missouri), in Ringgold County, T. 70 N., R. $30 \mathrm{~W}$.

Plumb Creek (L); Woodbury County; rises in T. 87 N., R. 43 W.; flows west 2 miles into Little Sioux River (tributary to the Missouri).

Plymouth Creek (L); Plymouth County; rises in T. 92 N., R. 44 W.; flows southwest 12 miles into Floyd River (tributary to the Missouri) in T. 92 N., R. 45 W.

Poney Creek (L); Pottawattamie County; rises in sec. 30, T. 75 N., R. 47 W.; flows southwest 7 miles through Car Lake into Mosquito Creek (tributary to the Missouri) in T. 74 N.; R. $43 \mathrm{~W}$.

Poney Creek, Little (L); Pottawattamie County; rises in sec. 34, T. 75 N., R. 43 W.; flows southwest $4 \frac{1}{2}$ miles into Mosquito Creek in T. 74 N., R. 43 W.

Pony Creek (R); Mills County; rises in T. 73 N., R. 43 W.; flows south $11 \frac{1}{2}$ miles into Keg Creek in T. 71 N., R. 43 W.

Pot Hole Creek (R); Decatur County; rises in T. 68 N., R. 27 W.; flows northeast 4 miles into Grand River (tributary to the Missouri) in T. 68 N., R. 26 W.

Potato Creek (R); Harrison County; rises in sec. 30, T. 79 N., R. 41 W.; flows southwest $13 \frac{1}{2}$ miles into Pigeon Creek (tributary to the Missouri) in Pottawattamie County, T. 77 N., R. 43 W.

Prairie Creek (R); Benton County; rises in T. 84 N., R. 11 W.; flows south 14 miles and east $29 \frac{1}{2}$ miles into Cedar River (tributary to the Mississippi), Linn County, at altitude 720 feet, T. 83 N., R. 7 W.

Prairie Creek (L); Benton County; rises in sec. 5, T. 86 N., R. 9 W.; flows southwest 10 miles into Cedar River (tributary through Iowa River to the Mississippi) in sec. 15, T. 85 N., R. 10 W.

Prairie Creek (R); Boone County; rises in sec. 1, T. 84 N., R. 26 W.; flows east 4 miles into Montgomery Creek (tributary through Squaw Creek to Skunk River and thus to the Mississippi) in sec. 34 , T. 85 N., R. 25 W.

Prairie Creek (R); Buchanan County; rises in sec. 4, T. 89 N., R. 7 W.; flows south and east 14 miles into Maquoketa River (tributary to the Mississippi) in Delaware County, T. 89 N., R. 5 W.

Prairie Creek (L); Calhoun County; rises in T. 78 N., R. 33 W.; flows southwest 10 miles into North Coon River in Calhoun County, T. 86 N., R. 34 W.

Prairie Creek (R); Clinton County; rises in T. 83 N., R. 2 E.; flows northeast 10 miles into Maquoketa River (tributary to the Mississippi) in Jackson County, sec. 17, T. 84 N., R. 3 E.

Prairie Creek (R); Dubuque County; rises in T. 88 N., R. 2 E.; flows south 6 miles into Lytle Creek (tributary through North Fork of Maquoketa River to Maquoketa River and thus to the Mississippi) in T. 87 N., R. 2 E.

Prairie Creek (R); Hamilton County; rises in sec. 5, T. 87 N., R. 26 W.; flows south 4 miles into Boone River (tributary through Des Moines River to the Mississippi) in sec. 28, T. 87 N., R. $26 \mathrm{~W}$.

Prairie Creek (R); Hancock County; rises in T. 95 N., R. 26 W.; flows southwest $14 \frac{1}{2}$ miles and southeast $12 \frac{1}{2}$ miles into Boone River (tributary through Des Moines River to the Mississippi) in Wright County, T. 93 N., R. 26 W.

Prairie Creek (L); Jasper County; rises in sec. 14, T. 81 N., R. 20 W.; flows south 11 miles into Skunk River (tributary to the Mississippi) in sec. 3, T. 79 N., R. $20 \mathrm{~W}$.

Prairie Creek (R); Jasper County; rises in T. 78 N., R. 21 W.; flows southeast 11 miles into Calhoun Creek (tributary through Des Moines River to the Mississippi) in Marion County, T. 77 N., R. 20 W. 
Prairie Creek (L); Johnson County; rises in T. 77 N., R. 5 W.; flows south 8 miles into Iowa River (tributary to the Mississippi) in Louisa County, T. 76 N., R. 5 W.

Prairie Creek (L); Kossuth County; rises in T. 99 N., R. 30 W.; flows southeast 9 miles into East Des Moines River (tributary through Des Moines River to the Mississippi) in T. 98 N., R. 30 W.

Praírie Creek(L); Palo Alto County; rises in T. 96 N., R. 31 W.; flows generally south 18 miles into Des.Moines River (tributary to the Mississippi) in T. 93 N., R. 31 W.

Prairie Creek (R); Tama County; rises in sec. 16, T. 84 N., R. 16 W.; flows southwest 3 miles into Deer Creek (tributary through Iowa River to the Mississippi).

Prairie Creek (R); Webster County; rises in sec. 13, T. 88 N., R. 30 W.; flows southeast 18 miles into Des Moines River (tributary to the Mississippi) in sec. 35, T. 88 N., R. 28 W.

Pratt Creek (R); Benton County; rises in T. 84 N., R. 12 W.; flows northeast 13 miles into Cedar River (tributary to the Mississippi) in T. 86 N., R. 10 W., 3 miles northwest of Vinton.

Prescotts Creek (R); Blackhawk County; rises in sec. 31, T. 88 N., R. 13 W.; flows north 5 miles into Blackhawk Creek (tributary through Cedar Creek to Iowa River and thus to the Mississippi) in sec. 12, T. 88 N., R. $14 \mathrm{~W}$.

Price Creek (L); Iowa County; rises in sec. 4, T. 81 N., R. 10 W.; flows southeast 10 miles into Iowa River (tributary to the Mississippi) in sec. 26, T. 81 N., R. 9 W.

Price Creek (R); Lee County; rises in sec. 4, T. 65 N., R. 5 W.; flows southeast 5 miles into Mississippi River.

Private Creek (L); Benton County; rises in T. 86 N., R. 9 W.; flows southwest 8 miles into Cedar River (tributary through Iowa River to the Mississippi) in T. $85 \mathrm{~N} .$, R. $10 \mathrm{~W}$., at Vinton. (Called Prairie Creek on county map of Benton County, Iowa Geol. Survey Ann. Rept., vol. 15.)

Pumpkin Run (R); Jackson County; rises in T. 84 N., R. 2 E.; flows northeast 5 miles into South Fork of Maquoketa River (tributary to the Mississippi) in T. 84 N., R. 1 E.

Purell Creek (L); Kossuth County; rises in sec. 36, T. 96 N., R. 28 W.; flows north and west 7 miles into Des Moines River (tributary to the Mississippi) in Kossuth County, sec. 19, T. 95 N., R. 28 W.

Purgatory Creek (L); Calhoun County; rises in T. 87 N., R. 32 W.; flows southwest 19 miles into Raccoon River (tributary through Des Moines River to the Mississippi) in Carroll County, T. 84 N., R. 33 W.

Quarter Section Run (L); Bremer County; rises in sec. 28, T. 93 N., R. 13 W.; flows south and west 17 miles into Cedar River (tributary through Iowa River to the Mississippi) in sec. 19, T. 91 N., R. $13 \mathrm{~W}$.

Raccoon River (R); Buena Vista County; rises in sec. 28, T. 92 N., R. 36 W., and flows 15 miles nearly due south. In Buena Vista County the stream is known as Coon River. It flows into Sac County, where it is still called Coon River. It flows slightly southeastward 31 miles and enters Calhoun County, where it flows southeastward about 10 miles. In this county it is known as North Coon River. After leaving Calhoun County it flows into Carroll County. Here it flows southeastward for about 12 miles. In this county it is known as North Coon River. After leaving Carroll County it flows southeastward across Greene County a distance of about 41 miles, and in this county its name is Raccoon River. The Raccoon River flows through Dallas County about due south for 36 miles. In this county it is known as North Raccoon River. In sec. 21, T. 78 N., R. 27 W. it joins South Raccoon River, below which junction the name Raccoon River is used. In Polk County the Raccoon River flows southeast 12 miles and joins the Des Moines River in sec. 10, T. 78 N., R. 24 W. Prairie Creek rises in sec. 16, T. 87 N., R. 33 W., and joins the North Coon River in sec. 22, T. 86 N., R. $34 \mathrm{~W}$. 
Raccoon River, Middle (R); Carroll County; rises in T. 85 N., R. 36 W.; flows southeast 76 miles into Raccoon River (tributary through Des Moines River to the Mississippi) in Dallas County, T. 78 N., R. 29 W.

Raccoon River, North. See Raccoon River.

Raccoon River, South (R); Audubon County; rises in T. 81 N., R. 34 W.; flows southeast 54 miles into Middle Raccoon River (tributary through Raccoon River to Des Moines River and thus to the Mississippi) in Dallas County, T. 78 N., R. 29 W. Water power is developed at Guthrie Center, where a 14-foot head creates 60 horsepower, and at Dale, where a $6 \frac{1}{2}$-foot head creates 35 horsepower.

Ragg Creek (L); Sioux County; rises in sec. 25, T. 97 N., R. 46 W.; flows west and northwest 4 miles into Rock River (tributary through Big Sioux River to the Missouri) in T. 97 N., R. 46 W.

Rapid Creek (L); Johnson County; rises in sec. 13, T. 80 N., R. 5 W.; flows southwest 9 miles into Iowa River (tributary to the Mississippi) in sec. 34, T. 80 N., R. $6 \mathrm{~W}$.

Rat Creek (L); Osceola County; a small tributary to West Rat Creek (tributary through Little Otter Creek to Rock River, which discharges into the Missouri through Big Sioux River) in Lyon County, T. 98 N., R. 43 W.; length, 4 miles.

Rat Creek, West (R); Osceola County; rises in T. 99 N., R. 42 W.; flows southwest $7 \frac{1}{2}$ miles into Little Otter Creek (tributary through Rock River to Big Sioux River and thus to the Missouri) in Lyon County, T. 98 N., R. $43 \mathrm{~W}$.

Raven Creek (R); Marshall County; rises in sec. 3, T. 82 N., R. 17 W.; flows northwest 12 miles into Iowa River (tributary to the Mississippi) in sec. 25, T. 83 N., R. $16 \mathrm{~W}$.

Red Cedar River. (See Cedar River.)

Reeds Creek (L); Adams County; rises in T. 73 N., R. 35 W.; flows southwest 8 miles into West Nodaway River (tributary through Nodaway River to the Missouri) in Montgomery County, sec. 33, T. 73 N., R. $36 \mathrm{~W}$.

Reynolds Creek (R); Woodbury County; rises in T. 87 N., R. 42 W.; flows south 10 miles into Maple River (tributary through Little Sioux River to the Missouri) in T. 86 N., R. 42 W.

Richland Creek (R); Keokuk County; rises in sec. 35, T. 74 N., R. 11 W.; flows east 4 miles and northeast $7 \frac{1}{2}$ miles into Skunk River (tributary to the Mississippi) in Washington County, T. 74 N., R. 9 W.

Richland Creek (R); Poweshiek County; rises in T. 81 N., R. 16 W.; flows east 181 miles into Iowa River (tributary to the Mississippi) in Tama County, T. 82 N., R. $14 \mathrm{~W}$.

Roberts Creek (L); Clayton County; rises in T. 95 N., R. 6 W.; flows southeast 17 miles and south 8 miles into Turkey River (tributary to the Mississippi) in T. 93 N., R. 5 W., at altitude 700 feet.

Rock Creek (L); Blackhawk County; rises in sec. 28, T. 87 N., R. 14 W.; flows southwest 11 miles into Wolf Creek (tributary through Cedar River to Iowa River and thus to the Mississippi) in Tama County, T. 86 N., R. 13 W.

Rock Creek (R); Cedar County; rises in T. 81 N., R. 1 W.; flows southeast 5 miles and east $6 \frac{1}{2}$ miles into Wapsipinicon River (tributary to the Mississippi) in Clinton County, T. 81 N., R. 1 E.

Rock Creek (L); Cedar County; rises in T. 82 N., R. 3 W.; flows south 19 miles into Cedar River (tributary through Iowa River to the Mississippi) in sec. 2, T. 79 N., R. 3 W.

Rock Creek (R); Cherokee County; rises in T. 92 N., R. 41 W.; flows south 15 miles into Little Sioux River (tributary to the Missouri) in T. 90 N., R. 41 W.

Rock Creek (L); Fremont County; rises in sec. 13, T. 67 N., R. 40 W.; flows southwest 4 miles into the State of Missouri, sec. 34, T. 67 N., R. 40 W. 
Rock Creek (R); Jackson County; rises in T. 84 N., R. 4 E.; flows northeast 5 miles into Maquoketa River (tributary to the Mississippi).

Rock Creek (L); Jefferson County; rises in sec. 24, T. 71 N., R. 9 W.; flows southeast 5 miles into Cedar Creek (tributary through Skunk River to the Mississippi) in sec. 33 , T. 71 N., R. 8 W.

Rock Creek (L); Jasper County; rises in sec. 2, T. 81 N., R. 18 W.; flows south 16 miles into North Skunk River (tributary through Skunk River to the Mississippi) in T. 79 N., R. 17 W.

Rock Creek (L); Keokuk County; rises in sec. 34, T. 77 N., R. 13 W.; flows southeast 13 miles into Cedar Creek (tributary through North Skunk River to Skunk River and thus to the Mississippi) in sec. 9, T. 75 N., R. 12 W.

Rock Creek (R); Keokuk County; rises in T. 74 N., R. 11 W.; flows north $6 \frac{1}{2}$ miles into South Skunk River (tributary through Skunk River to the Mississippi) in sec. 2, T. 74 N., R. 11 W.

Rock Creek (L); Marshall County; rises in sec. 13, T. 84 N., R. 17 W.; flows southwest 4 miles into Iowa River (tributary to the Mississippi).

Rock Creek (R); Mitchell County; rises in T. 98 N., R. 18 W.; flows southeast $15 \frac{1}{2}$ miles into Cedar River (tributary through Iowa River to the Mississippi) between Mitchell and Floyd counties, T. 97 N., R. 17 W.

Rock Creek (L); Poweshiek County; rises in sec. 24, T. 81 N., R. 14 W.; flows southeast 7 miles into Bear Creek (tributary through Iowa River to the Mississippi) in sec. 22 , T. 80 N., R. $13 \mathrm{~W}$.

Rock Creek (R); Tama County; rises in T. 85 N., R. 13 W.; flows northeast 14 miles into Cedar River (tributary to the Mississippi) in Blackhawk County, T. 87 N., R. $11 \mathrm{~W}$.

Rock Creek (R); Wapello County; rises in T. 71 N., R. 12 W.; flows east 9 miles into Cedar River (tributary through Skunk River to the Mississippi) in Jefferson County, T. 72 N., R. 11 W.

Rock Creek (R); Woodbury County; rises in sec. 34, T. 89 N., R. 44 W.; flows southeast 6 miles into Little Sioux River (tributary to the Missouri) in T. 88 N., R. $43 \mathrm{~W}$.

Rock Creek, Little (L); rises in a lake in Nobles County, Minn. (T. 102 N., R. 41 W.); enters Osceola County (T. 100 N., R. 42 W.) and flows irregularly southwest 33 miles into Rock River (tributary through Big Sioux River to the Missouri) in the southeastern part of T. 98 N., R. 46 W., Lyon County.

Rock River (L); rises in Pipestone County, Minn.; enters Iowa through Lyon County (T. 100 N., R. 45 W.); flows south 10 miles and generally southwest 29 miles into Big Sioux River (tributary to the Missouri) in Sioux County, T. 95 N., R. 48 W.

Rock Run (L); Cedar County; rises in T. 82 N., R. 4 W.; flows southeast 14 miles into Cedar River (tributary through Iowa River to the Mississippi) in Cedar County, sec. 28, T. 80 N., R. 3 W.

Rock Run (R); Clinton County; rises in T. 81 N., R. 1 E.; flows southeast and northeast 7 miles into Wapsipinicon River (tributary to the Mississippi).

Rocky Branch $(\mathrm{R})$; Jefferson County; rises in sec. 3, T. 72 N., R. 9 W.; flows west 6 miles into Walnut Creek (tributary through Skunk River to the Mississippi) in sec. 3 , T. 72 N., R. 8 W.

Rush Creek (R); Monona County; rises in sec. 1, T. 85 N., R. 42 W.; flows south 6 miles into Soldier River (tributary to the Missouri) in Monona County, sec. 2, T. 84 N., R. 42 W.

Rush Lake Outlet (L); rises in Rush Lake, Osceola County, sec. 30, T. 100 N., R. 40 W.; flows south 4 miles into Ocheyedan River in Osceola Oounty, sec. 23, T. 99 N., R. 40 W. 
St. Josef Creek (L); Mahaska County; rises in T. 75 N., R. 17 W.; flows southeast 10 miles into Des Moines River (tributary to the Mississippi) in Mahaska County, T. 74 N., R. 16 W.

Sage Creek (R); Monroe County; rises in sec. 6, T. 73 N., R. 19 W.; flows north 6 miles into North Cedar River (tributary through Des Moines River to the Mississippi).

Salt Creek (L); Tama County; rises in T. 85 N., R. 15 W.; flows east 8 miles and southeast 22 miles into Iowa River (tributary to the Mississippi) in T. 82 N., R. 13 W.

Salt Creek, East Branch (L); Tama County; rises in sec. 13, T. 85 N., R. 13 W.; flows south 12 miles into Salt Creek (tributary through Iowa River to the Mississippi) in sec. 34, T. 84 N., R. $13 \mathrm{~W}$.

Salt Creek, South Branch (R); Tama County; rises in sec. 3, T. 84 N., R. 15 W.; flows southeast 12 miles into Salt Creek (tributary through Iowa River to the Mississippi) in sec. 29 , T. 84 N., R. 13 W.

Sand Creek (R); Buchanan County; rises in sec. 21 , T. 87 N., R. 8 W.; flows northeast and southeast 5 miles into Wapsipinicon River (tributary to the Mississippi).

Sand Creek $(\mathrm{R})$; Union County; rises in T. 71 N., R. 29 W.; flows southeast 9 miles into Twelvemile Creek in T. 71 N., R. 28 W.

School Creek (L); Hardin County; rises in T. 89 N., R. 20 W.; flows southwest $4 \frac{3}{4}$ miles into Iowa River (tributary to the Mississippi) in T. 89 N., R. 20 W.

Seeley Creek (R); Guthrie County; rises in T. 79 N., R. 33 W.; flows east 10 miles into Wichita Creek (tributary through Raccoon River to Des Moines River and thus to the Mississippi) in sec. 35, T. .80 N., R. 32 W.

Sevenmile Creek (R); Cass County; rises in T. 77 N., R. 34 W.; flows southwest 23 miles and south $12 \frac{1}{2}$ miles into West Nodaway River (tributary through Nodaway River to the Missouri) in Montgomery County, T. 73 N., R. 36 W.

Sevenmile Creek (L); Decatur County; rises in sec. 35, T. 68 N., R. 27 W.; flows south 6 miles through Decatur County into the State of Missouri, sec. 26, T. 67 N., R. $27 \mathrm{~W}$.

Shane Creek (R); Decatur County; rises in sec. 33, T. 68 N., R. 27 W.; flows south $5 \frac{1}{2}$ miles through Decatur County into the State of Missouri, sec. 29, T. 67 N., R. 27 W.

Shellrock River (R); rises in Freeborn County, Minn.; enters Iowa through Worth County (T. 100 N., R. 21 W.); flows southeast 81 miles into Cedar River (tributary through Iowa River to the Mississippi) in Blackhawk County, T. 90 N., R. 14 W. Water power is developed at five localities. At Shellrock a 6 -foot head creates 200 horsepower; at Greene an 8-foot head creates 175 horsepower; at Nora Springs a 10-foot head creates 72 horsepower; at Northwood an 8-foot head creates 85 horsepower; at Rockford an 8-foot head creates 65 horsepower.

Shellrock River, West Fork $(\mathrm{R})$; formed by the junction of Bailey and Beaver Dam creeks in Franklin County, T. 93 N., R. 19 W.; flows southeast 39 miles into Shellrock River (tributary through Cedar River to Iowa River and thus to the Mississippi) in Blackhawk County, T. 90 N., R. 14 W., 1 mile above point where Shellrock River flows into Cedar River.

Shoal Creek (R); Wayne County; rises in sec. 22, T. 68 N., R. 20 W.; flows east 11 miles and southeast 7 miles through Appanoose County into the State of Missouri in T. $67 \mathrm{~N} ., \mathrm{R} .17 \mathrm{~W}$.

Short Creek (L); Warren County; rises in sec. 30, T. 76 N., R. 23 W.; flows northeast 7 miles into South River in sec. 18, T. 76 N., R. 22 W.

Short Creek (R); Louisa County; rises in T. 75 N., R. 5 W.; flows southeast 9 miles into Iowa River (tributary to the Mississippi) in Louisa County, T. 75 N., R. 4 W.

Silver Creek (R); Allamakee County; rises in T. 98 N., R. 5 W.; flows north 9 miles into Upper Iowa River (tributary to the Mississippi) in Allamakee County, T. 99 N., R. 5 W. 
Silver Creek (L); Buena Vista County; rises in T. 91 N., R. 38 W.; flows west 13 miles into Maple River (tributary through Little Sioux River to the Missouri) in Ida County, T. 88 N., R. 40 W.

Silver Creek (L); Cherokee County; rises in T. 89 N., R. 40 W.; flows north 13 miles into Little Sioux River (tributary to the Missouri) in T. 91 N., R. 40 W.

Silver Creek (L); Clayton County; rises in T. 95 N., R. 5 W.; flows east and south 10 miles into Roberts Creek (tributary through Turkey River to the Mississippi) in Clayton County, T. 94 N., R. 5 W.

Silver Creek (R); Jackson County; rises in T. 84 N., R. 3 E.; flows northwest 2 miles into Prairie Creek (tributary through Maquoketa River to the Mississippi).

Silver Creek (R); Linn County; rises in T. 83 N., R. 8 W.; flows northeast 6 miles into Cedar River (tributary through Iowa River to the Mississippi).

Silver Creek (L); Sac County; rises in sec. 1, T. 88 N., R. 38 W.; flows west and southwest 13 miles into Maple River (tributary through Little Sioux to the Missouri) in T. 88 N., R. $40 \mathrm{~W}$.

Silver Creek (L); Scott County; rises in sec. 4, T. 78 N., R. 3 E.; flows southeast 4 miles into Duck Creek (tributary to the Mississippi).

Silver Creek (R); Shelby County; rises in T. 80 N., R. 39 W.; flows south 10 miles and southwest $52 \frac{1}{2}$ miles into West Nishnabotna River (tributary through Nishnabotna River to the Missouri) in Mills County, T. 71 N., R. 41 W.

Silver Creek (L); Winneshiek County; rises in sec. 13, T. 100 N., R. 9 W.; flows south 7 miles into Upper Iowa River (tributary to the Mississippi) in Winneshiek County, sec. 10, T. 99 N., R. 9 W.

Silver Creek, Little (R); Pottawattamie County; rises in sec. 11, T. 76 N., R. 41 W.; flows southwest 12 miles into Middle Branch of Silver Creek (tributary through Silver Creek to the Missouri) in sec. 12, T. 74 N., R. 42 W.

Silver Creek, Little (R); Shelby County; rises in T. 79 N., R. 39 W.; flows south $7 \frac{1}{2}$ miles into Silver Creek (tributary to the Missouri) in T. 78 N., R. 40 W.

Silver Creek, Middle Branch (R); Pottawattamie County; rises in T. $77 \mathrm{~N}$, R. $40 \mathrm{~W}$.; flows southwest 22 miles and southeast $4 \frac{1}{2}$ miles into Silver Creek (tributary to the Missouri) in T. 74 N., R. 41 W.

Simon's R un (L); Pottawattamie County; rises in sec. 28, T. 76 N., R. 43 W.; flows northwest and southwest 5 miles into Pigeon Creek (tributary to Missouri River) in sec. 13 , T. 76 N., R. $44 \mathrm{~W}$.

Sink Creek (R); Blackhawk County; rises in sec. 23, T. 88 N., R. 12 W.; flows northeast 4 miles into Cedar River (tributary through Iowa River to the Mississippi).

Sioux Creek (L); Harrison County; rises in sec. 2, T. 81 N., R. 43 W.; flows southwest and north 8 miles into Soldier River (tributary to the Missouri) in Monona County, sec. 31, T. 82 N., R. 43 W. (Written "Stowe" on Harrison County map, Ann. Rept. Iowa Geol. Survey, vol. 20.)

Sioux River, Big (L); forms western boundary of Iowa along the counties of Lyon, Sioux, and Plymouth; flows into Missouri River at Sioux City, T. 90 N., R. 48 W. Water power is developed at Akron, where an 8-foot head creates 100 horsepower; at Calliope a 6 -foot head creates 80 horsepower.

Sioux River, Little (L); rises in Jackson County, Minn. (T. 103 N., R. 37 W.); enters Iowa through Dickinson County, sec. 12, T. 100 N., R. 38 W.; flows south 36 , east 4 , south 9 , southwest 13 , west 13 , northwest 4 , and southwest 100 miles into Missouri River in Harrison County, T. 81 N., R. 45 W. Water power is developed at four localities-at Sioux Rapids, where an 8-foot head creates 100 horsepower; at Peterson, where an 11-foot head creates 150 horsepower; at Smithland, where a 5-foot head creates 75 horsepower; and at Linn Grove, where a 9-foot head creates 47 horsepower. 
Sioux River, Little, West Fork (L); Cherokee County; rises in T. 93 N., R. 41 W.; flows southwest 42, south 27, and southeast 8 miles into Little Sioux River (tributary to the Missouri) in Monona County, sec. 25, T. 84 N., R. 45 W.

Sixmile Creek (L); Sioux County; rises in T. 96 N., R. 46 W.; flows southwest 11, west 4, and southwest 10 miles into Big Sioux River (tributary to the Missouri) in the southwest corner of Sioux County, T. 94 N., R. 48 W.

Skeleton River (L); Lee County; rises in T. 67 N., R. 6 W.; flows southwest 3 miles into Sugar Creek (tributary through Des Moines River to the Mississippi).

Skiller Creek $(\mathrm{R})$; formed by junction of two small streams in Webster County; sec. 14, T. 86 N., R. 28 W.; flows east about 6 miles into Des Moines River (tributary to the Mississippi) in sec. 16, T. 86 N., R. 27 W.

Skinners Creek (L); Monona County; rises in sec. 14, T. 83 N., R. 42 W.; flows southwest $4 \frac{1}{2}$ miles into Soldier River (tributary to the Missouri) in sec. 19, T. 83 N., R. 42 W.

Skunk Creek (R); Monona County; rises in sec. 22 , T. 85 N., R. 42 W.; flows south 6 miles into Soldier Creek (tributary to the Missouri) in sec. 15, T. 84 N., R. 42 W.

Skunk River (R); Hamilton County; rises in T. 89 N., R. 23 W.; flows south 46 miles and southeast 30 miles to Colfax, southeast 81 miles, east 23 miles, and southeast 70 miles into Mississippi River in Des Moines County, T. 68 N., R. $2 \mathrm{~W}$. Waterpower is developed at Brighton, where a 5 -foot head creates 35 horsepower. At Lowell no data are available.

Skunk River, North (L); Marshall County; rises in T. 83 N., R. 19 W.; flows southeast 101 miles into Skunk River (tributary to the Mississippi) in Keokuk County, T. 75 N., R. $10 \mathrm{~W}$.

Slough Creek (R); Dallas County; rises in sec. 34, T. 80 N., R. 27 W.; flows north 10 miles into Beaver Creek (tributary through Des Moines River to the Mississippi) in sec. 14, T. 81 N., R. 27 W.

Smith Creek (R); Des Moines County; rises in sec. 13, T. 72 N., R. 3 W.; flows northwest 5 miles into Otter Creek (tributary through Iowa River to the Mississippi) in Louisa County, T. 73 N., R. 3 W.

Smith Creek (R); Keokuk County; rises in T. 77 N., R. 11 W.; flows east 18 miles into South English River (tributary through Iowa River to the Mississippi) in Washington County, T. 77 N., R. 8 W.

Smiths Run (L); Muscatine County; rises in T. 76 N., R. 3 W.; flows northwest 6 miles into Cedar River (tributary through Iowa River to the Mississippi) in T. 76 N., R. 4 W.

Snake Creek (L); Page County; rises in sec. 3, T. 69 N., R. 37 W.; flows southwest 8 miles into East Tarkio Creek (tributary through Tarkio Creek to the Missouri) in sec. 10, T. 68 N., R. 38 W.

Snipe Creek (L); Marshall County; rises in sec. 24, T. 82 N., R. 19 W.; flows south 11 miles into North Skunk River (tributary through Skunk River to the Mississippi) in Jasper County, T. 80 N., R. 19 W.

Snipe Creek (L); Marshall County; rises in sec. 26, T. 82 N., R. 18 W.; flows northeast $5 \frac{1}{2}$ miles into Lutes Creek (tributary through Timber Creek to Iowa River and thus to the Mississippi) in sec. 18, T. 82 N., R. 17 W.

Snort Creek (L); Appanoose County; rises in T. 69 N., R. 17 W.; flows southwest $2 \frac{1}{2}$ miles into Chariton River (tributary to the Missouri).

Sny Magill Creek (R); formed by the union of several small branches in Clayton County, T. 94 N., R. 3 W.; flows southeast about 5 miles into Mississippi River in T. 94 N., R. 3 W.

Soap Creek (L); Mitchell County; rises in sec. 28, T. 99 N., R. 15 W.; flows southwest 5 miles into Little Cedar River (tributary through Cedar River to Iowa River and thus to the Mississippi) in sec. 18, T. 98 N., R. $15 \mathrm{~W}$. 
Soap Creek, Big (R); Monroe County; rises in T. 71 N., R. 17 W.; flows southeast 15 miles and northeast $21 \frac{1}{2}$ miles into Des Moines River (tributary to the Mississippi) at Eldon, Wapello County, T. 71 N., R. 12 W.

Soap Creek, Little (L); Monroe County; rises in T. 71 N., R. 16 W.; flows east 9 miles and southeast 10 miles into Soap Creek (tributary through Little Cedar River to Cedar River, which discharges in to the Mississippi through Iowa River) in Davis County, T. 70 N., R. 13 W.

Soap Creek, South (R); Appanoose County; rises in T. 70 N., R. 17 W.; flows southeast 12 miles and northeast 3 miles into Soap Creek (tributary through Little Cedar River to Cedar River, which discharges into the Mississippi through Iowa River) in Davis County, T. 70 N., R. 15 W.

Soldier Creek $(R)$; rises in Tremont Lake in Emmet County, T. 100 N., R. 32 W.; flows southeast 6 miles into East Branch of Des Moines River (tributary through Des Moines River to the Mississippi) in sec. 36, T. 100 N., R. 32 W.

Soldier Creek (L); Humboldt County; rises in T. 91 N., R. 27 W.; flows southwest 19 miles into Des Moines River (tributary to the Mississippi) at Fort Dodge, Webster County, T. 89 N., R. 28 W.

Soldier River (L); Ida County; rises in T. 86 N., R. 39 W.; flows southwest 72 miles into Missouri River in Harrison County, T. 78 N., R. 45 W.

Soldier River, East Fork (L); Crawford County; rises in T. 85 N., R. 39 W.; flows southwest $19 \frac{1}{2}$ miles into Soldier River (tributary to the Missouri) in Monona County, T. 84 N., R. 42 W.

South River (R); Clark County; rises in T. 73 N., R. 27 W.; flows northeast 53 miles into Des Moines River (tributary to the Mississippi) in Marion County, T. 77 N., R. $21 \mathrm{~W}$.

South. (See also significant name.)

South Branch. (See significant name.)

South Fork. (See significant name.)

Spencer Creek (R); Scott County; rises in sec. 17, T. 79 N., R. 4 E.; flows southeast $8 \frac{1}{2}$ miles into Mississippi River in Scott County, sec. 7, T. 78 N., R. 5 E.

Spring Branch (R); Carroll County; rises in sec. 24, T. 83 N., R. 35 W.; flows east 6 miles into Middle Branch of Raccoon River (tributary through Raccoon River to Des Moines River and thus to the Mississippi) in Carroll County, T. 83 N., R. $34 \mathrm{~W}$.

Spring Branch (L); Jones County; rises in sec. 9, T. 84 N., R. 3 W.; flows southwest 4 miles into Wapsipinicon River (tributary to the Mississippi).

Spring Branch Creek (L); Worth County; rises in T. 98 N., R. 20 W.; flows south 7 miles into Lime Creek (tributary through Shellrock River to Cedar River, which discharges into the Mississippi through Iowa River) at Madison City, Cerro Gordo County, sec. 28, T. 97 N., R. 20 W.

Spring Creek (L); Buchanan County; rises in T. 88 N., R. 10 W.; flows southwest 5 miles and south 13 miles into Cedar. River (tributary through Iowa River to the Mississippi) in Blackhawk County, T. 87 N., R. 11 W.

Spring Creek (R); Clay County; rises in sec. 33, T. 96 N., R. 38 W.; flows northeast 6 miles into Ocheyedan River (tributary through Little Sioux River to the Missouri) in sec. 2 , T. 96 N., R. $38 \mathrm{~W}$.

Spring Creek (R); 10 miles long; rises in Clayton County and flows in a northeasterly direction into Volga River (tributary through Turkey River to the Mississippi).

Spring Creek (R); Des Moines County; rises in sec. 28, T. 70 N., R. 3 W.; flows southeast 10 miles into Mississippi River in Des Moines County, T. 69 N., R. 2 W.

Spring Creek (R); Franklin County; rises in T. 92 N., R. 22 W.; flows east 17 miles into Otter Creek (tributary through Hartgrave Creek to Shellrock River, a branch of Cedar River, which discharges into the Mississippi through Iowa River) in T. 92 N., R. 19 W. 
Spring Creek (R); Harrison County; rises in sec. 12, T. 79 N., R. 41 W.; flows south 7 miles into Mosquito Creek (tributary to the Missouri) in T. 78 N., R. 41 W.

Spring Creek (L); Linn County; rises in T. 82 N., R. 5 W.; flows southwest 6 miles into Cedar River (tributary through Iowa River to the Mississippi).

Spring Creek (L); Mitchell County; rises in sec. 19, T. 98 N., R. 15 W.; flows south 7 miles into Red Cedar River (tributary through Iowa River to the Mississippi) in T. 97 N., R. 17 W.

Spring Creek (R); Webster County; rises in sec. 34, T. 88 N., R. 30 W.; flows northeast 7 miles into South Branch of Lizard Creek (tributary through Des Moines River to the Mississippi) in sec. 33, T. 89 N., R. 29 W.

Spring Valley Creek (L); Mills County; rises in sec. 15, T. 71 N., R. 42 W.; flows southeast 6 miles into West Nishnabotna River (tributary through Nishnabotna River to the Missouri) in sec. 32 , T. 71 N., R. 41 W.

Spruce Creek (R); Jackson County; rises in sec. 21, T. 87 N., R. 4 E.; flows southeast and northeast 8 miles into the Mississippi.

Squaw Creek (R); -Clarke County; rises in T. 72 N., R. 27 W.; flows northeast 35 miles into South River (tributary through Des Moines River to the Mississippi) in Warren County, T. 75 N., R. 24 W.

Squaw Creek (R); Franklin County; rises in sec. 30, T. 92 N., R. 20 W.; flows 11 miles generally eastward from Hartgrave Creek in junction with Otter Creek in Franklin County, sec. 28, T. 92 N., R. 19 W.

Squaw Creek (R); Hamilton County; rises in T. 87 N., R. 26 W.; flows southeast 24 miles to Ames, southeast $2 \frac{1}{2}$ miles into Skunk River (tributary to the Mississippi) in Story County, T. 83 N., R. 24 W.

Squaw Creek (R); Jasper County; rises in sec. 32, T. 79 N., R. 20 W.; flows northwest 8 miles into Skunk River (tributary to the Mississippi), sec. 3, T. 79 N., R. $21 \mathrm{~W}$.

Squaw Creek (L); Linn County; rises in sec. 28, T. 84 N., R. 6 W.; flows southwest 8 miles into Indian Creek (tributary through Cedar River to Iowa River and thus to the Mississippi) in T. 83 N., R. 6 W.

Staff Creek (R); Howard County; rises in sec. 19, T. 100 N., R. 14 W.; flows northeast 7 miles into Upper Iowa River (tributary to the Mississippi) in T. 100 N., R. $13 \mathrm{~W}$. One small tributary enters from the left in sec. 26, T. 100 N., R. 14 W.

Stafford Creek (R); Audubon County; rises in T. 79 N., R. 35 W.; flows south 5 miles into Nishnabotna River (tributary to the Missouri) in Audubon County, T. 78 N., R. 35 W.

Steady Run (R); Keokuk County; rises in sec. 27, T. 74 N., R. 12 W.; flows northwest 6 miles into South Skunk River (tributary through Skunk River to the Mississippi).

Steele Creek (L); Decatur County; rises in T. 69 N., R. 24 W.; flows southeast and southwest 16 miles into Weldon River (tributary through Grand River to the Missouri) in T. 67 N., R. 24 W.

Steeles Branch (L); Delaware County; rises in T. 90 N., R. 5 W.; flows northeast 6 miles into Elk Creek (tributary through Turkey River to the Mississippi) in T. 91 N., R. 4 W. Total fall, about 300 feet.

Steeles Branch (L); Madison County; rises in T. 75 N., R. 26 W.; flows east $3 \frac{1}{2}$ miles into Clanton Creek (tributary through Middle River to the Mississippi) in T. 75 N., R. $26 \mathrm{~W}$.

Steer Creek (L); Harrison County; rises in T. 81 N., R. 43 W.; flows southwest 12 miles into Soldier River (tributary to the Missouri) in T. 79 N., R. 44 W.

Stein Creek (L); Benton County; rises in sec. 28, T. 83 N., R. 12 W.; flows southeast 12 miles into Iowa River (tributary to the Mississippi) in sec. 7, T. 82 N., R. $12 \mathrm{~W}$. 


\section{CONTRIBUTIONS TO HYDROLOGY OF UNITED STATES, 1914.}

Stony Creek (L); formed by union of two small creeks in Dickinson County, T. 99 N., R. 38 W.; flows south 6 , southeast 5 , south 2 , and southeast 9 miles into Ocheyedan River (tributary through Little Sioux River to the Missouri) in Clay County, T. 96 N., R. 37 W.

Stony Creek (L); Poweshiek County; rises in T. 81 N., R. 14 W.; flows southeast 6 miles into Bear Creek (tributary through Iowa River to the Mississippi) in T. 80 N., R. $14 \mathrm{~W}$.

Storm Creek (L); Carroll County; rises in sec. 23, T. 85 N., R. 35 W.; flows southeast 12 miles into Middle Raccoon River (tributary through Raccoon River to Des Moines River and thus to the Mississippi) in T. 84 N., R. 34 W.

Stratton Creek (L); Cherokee County; rises in sec. 36, T. 90 N., R. 41 W.; flows west 6 miles into Little Sioux River (tributary to the Missouri) in sec. 30, T. 90 N., R. $41 \mathrm{~W}$.

Sugar Creek (L); Cedar County; rises in T. 82 N., R. 2 W.; flows south 32 miles into Cedar River (tributary through Iowa River to the Mississippi) in Muscatine County, T. 78 N., R. 2 W.

Sugar Creek (L); Clinton County; rises in sec. 12, T. 83 N., R. 3 E.; flows northeast 8 miles into Deep Creek (tributary through Maquoketa River to the Mississippi) in Cedar County, T. 84 N., R. 5 E.

Sugar Creek (L); Dallas County; rises in sec. 2, T. 78 N., R. 27 W.; flows southeast 7 milesinto Raccoon River (tributary through Des Moines River to the Mississippi) in sec. 26 , T. 78 N., R. $26 \mathrm{~W}$.

Sugar Creek (L); Jasper County; rises in T. 81 N., R. 17 W.; flows south 19 miles into North Skunk River (tributary through Skunk River to the Mississippi) in Poweshiek County, T. 78 N., R. 16 W.

Sugar Creek (L); Lee County; rises in T. 69 N., R. 7 W.; flows southeast 30 miles into Des Moines River (tributary to the Mississippi) 6 miles west of Keokuk in T. 65 N., R. 6 W.

Sugar Creek (R); Marion County; rises in T. 77 N., R. 21 W.; flows east $5 \frac{3}{2}$ miles into Des Moines River (tributary to the Mississippi) in T. 77 N., R. 21 W.

Sugar Creek (L); Mitchell County; rises in sec. 10, T. 98 N., R. 17 W.; flows southeast 4 miles into Cedar River (tributary through Iowa River to the Mississippi).

Sugar Creek (L); Wapello County; rises in sec. 6, T. 72 N., R. 14 W.; flows southeast 3 miles and southwest 3 miles into Des Moines River (tributary to the Mississippi) in sec. 32, T. 72 N., R. $13 \mathrm{~W}$.

Sutton Creek (R); Lee County; rises in sec. 22, T. 69 N., R. 5 W.; flows southwest and northeast 8 miles into Skunk River (tributary to the Mississippi) in Henry County, T. 70 N., R. 5 W.

Swank Creek (R); Des Moines County; rises in sec. 23, T. 72 N., R. 3 W.; flows northeast 7 miles and southeast 2 miles into Mississippi River in sec. 24, T. 72 N., R. $1 \mathrm{~W}$.

Sweetland Creek (R); Muscatine County; rises in T. 77 N., R. 1 W.; flows south $4 \frac{1}{4}$ miles into Mississippi River in T. 77 N., R. 1 W.

Tarkio Creek, East (L); Montgomery County; rises in T. 71 N., R. 37 W.; flows southwest $20 \frac{1}{2}$ miles into Middle Tarkio Creek (tributary through Tarkio Creek to the Missouri) in Page County, T. 68 N., R. 38 W.

Tarkio Creek, Middle (L); Montgomery County; rises in T. 73 N., R. 37 W.; flows south 12 miles and southwest $32 \frac{1}{2}$ miles through Page County into the State of Missouri, T. 67 N., R. 38 W.

Tarkio Creek, West (R); Montgomery County; rises in T. 72 N., R. 37 W.; flows south 19 miles and southwest $21 \frac{1}{2}$ miles through Page County into the State of Missouri, T. 67 N., R. 39 W. 
Ten-Mile Creek (R); Winneshiek County; rises in sec. 30, T. 98 N., R. 9 W.; flows southeast and east 7 miles into Upper Iowa River (tributary to the Mississippi) in sec. 7, T. 98 N., R. 9 W.

Tete de Mort River (R); Dubuque County; rises in T. 88 N., R. 3 E.; flows south 6 miles and northeast 6 miles into Mississippi River in Jackson County, T. 87 N., R. $4 \mathrm{E}$.

Teter Creek (R); Marion County; rises in sec. 19, T. 76 N., R. 20 W.; flows northeast 7 miles into Des Moines River (tributary to the Mississippi) in sec. 6, T. 76 N., R. $19 \mathrm{~W}$.

Thompson Creek (L); Harrison County; rises in sec. 4, T. 80 N., R. 42 W.; flows southwest 5 miles into Willow Creek (tributary through Boyer River to the Missouri) in sec. 14, T. 80 N., R. $43 \mathrm{~W}$.

Threemile Creek (R); Adair County; rises in T. 74 N., R. 31 W.; flows southeast 21 miles into Grand River (tributary to the Missouri) in Union County, T. 72 N., R. $28 \mathrm{~W}$.

Thunder Creek (R); Marion County; rises in sec. 25, T. 77 N., R. 19 W.; flows northeast $6 \frac{1}{2}$ miles into South Skunk River (tributary through Skunk River to the Mississippi) in sec. 24, T. 77 N., R. 18 W.

Timber Creek (L); Harrison County; rises in sec. 21, T. 78 N., R. 42 W.; flows northwest 4 miles into Boyer River (tributary to the Missouri) in sec. 7, T. 78 N., R. $43 \mathrm{~W}$.

Timber Creek (R); Marshall County; rises in sec. 2, T. 82 N., R. 19 W.; flows northeast 18 miles into Iowa River (tributary to the Mississippi) in sec. 3, T. 83 N., R. $17 \mathrm{~W}$.

Timber Creek, Middle (R); Marshall County; rises in sec. 31, T. 83 N., R. 18 W.; flows east $7 \frac{1}{2}$ miles into North Timber Creek (tributary through Timber Creek to Iowa River and thus to the Mississippi) in sec. 24 , T. 83 N., R. 18 W.

Timber Creek, North (R); Marshall County; rises in sec. 9, T. 83 N., R. 20 W.; flows east 18 miles into Timber Creek (tributary through Iowa River to the Mississippi) in sec. 17, T. 83 N., R. $17 \mathrm{~W}$.

Tipton Creek (R); Hardin County; rises in T. 88 N., R. 22 W.; flows southeast $17 \frac{1}{2}$ miles into South Fork of Iowa River (tributary through Iowa River to the Mississippi) in T. 87 N., R. 20 W.

Tom Creek (L); Lyon County; rises in T. 100 N., R. 43 W.; flows west 15 miles into Rock River (tributary through Big Sioux River to the Missouri) at Rock Rapids.

Tracey Creek (L); Marion County; rises in sec. 11, T. 74 N., R. 21 W.; flows northeast 6 miles into English Creek (tributary through Des Moines River to the Mississippi) in sec. 27, T. 75 N., R. 20 W.

Troublesome Creek (L); Guthrie County; rises in T. 79 N., R. 33 W.; flows north 3 miles and southwest $26 \frac{1}{2}$ miles into East Nishnabotna River (tributary through Nishnabotna River to the Missouri) at Atlantic City, Cass County, T. 77 N., R. $36 \mathrm{~W}$.

Trout Creek (R); Winneshiek County; rises in sec. 30, T. 97 N., R. 8 W.; flows northeast 8 miles into Upper Iowa River (tributary to the Mississippi) in sec. 23, T. 98 N., R. 8 W.

Trullinger Creek (R); Humboldt County; rises in sec. 12, T. 93 N., R. 30 W.; flows east $6 \frac{1}{2}$ miles into Lotts Creek (tributary through East Des Moines River to Des Moines River and thus to the Mississippi) in sec. 18, T. 93 N., R. 28 W.

Turkey Creek (L); Cass County; rises in T. 76 N., R. 35 W.; flows southwest 10 miles into Nishnabotna River (tributary to the Missouri) in T. 75 N., R. 37 W.

Turkey Creek (L); Guthrie County; rises in T. 78 N., R. 33 W.; flows southwest $27 \frac{1}{2}$ miles into East Nishnabotna River (tributary to Nishnabotna River, which discharges into the Missouri) in Cass County, T. 75 N., R. 37 W.

$77145^{\circ}-15-4$ 
Turkey Creek (R); Jefferson County; rises in sec. 18, T. 72 N., R. 8 W.; flows northwest 5 miles into Skunk River (tributary to the Mississippi).

Turkey Creek (L); Johnson County; rises in T. 80 N., R. 6 W.; flows southwest 6 miles into Iowa River (tributary to the Mississippi) in T. 80 N., R. 6 W.

Turkey Creek, North (R); Adair County; rises in T. 77 N., R. 32 W.; flows southeast 103 miles into Middle River (tributary to Des Moines River, which discharges into the Mississippi) in T. 77 N., R. 31 W.

Turkey River (R); Howard County; rises in T. 99 N., R. 13 W.; flows southeast 88 miles into Mississippi River in Clayton County, T. 91 N., R. 2 W. Water power is developed at eight localities: At Eldorado an 8-foot head creates 70 horsepower; at Fort Atkinson a 10-foot head creates 100 horsepower; at Clermont a 14-foot head creates 280 horsepower; at Cresco a 9-foot head creates 18 horsepower; at Elgin an 8-foot head creates 200 horsepower; at Spillville an 8-foot head creates 73 horsepower. Plants are located at Elkader and Auburn, Fayette County, from which no data are available.

Turkey River, Little (R); Delaware County; rises in T. 90 N., R. 3 W., at altitude 1,020 feet above sea level; flows generally northeast 10 miles into Turkey River (tributary to the Mississippi) in Clayton County, T. 91 N., R. 2 W., at altitude 620 feet above sea level.

Turkey River, Iittle (R); Howard County; rises in T. 98 N., R. 11 W.; flows southeast 43 miles and northeast 5 miles into Turkey River (tributary to the Mississippi) in Fayette County, T. 95 N., R. 8 W. Water power is developed at Waucoma, where a $7 \frac{1}{2}$-foot head creates 50 horsepower.

Turkey River, South Branch (R); Howard County; rises in T. 99 N., R. 12 W.; flows east 7 miles into Turkey River (tributary to the Mississippi) in T. 99 N., R. $11 \mathrm{~W}$.

Turtle Creek (L); Mitchell County; rises in T. 99-N., R. 17 W.; flows southwest 5 miles into Red Cedar River (tributary through Iowa River to the Mississippi) in Mitchell County, sec. 23, T. 99 N., R. 18 W.

Twelvemile Creek (R); Adair County; rises in T. 74 N., R. 31 W.; flows southeast 32 miles into Grand River (tributary to the Missouri) in Union County, T. 71 N., R. $28 \mathrm{~W}$.

Twelvemile Creek (L); Tama County; rises in T. 86 N., R. 15 W.; flows southeast $13 \frac{1}{2}$ miles into Wolf Creek (tributary through Cedar River to Iowa River and thus to the Mississippi) in T. 86 N., R. 13 W. (Wolf Creek is called Big Creek on Blackhawk and Benton county maps, Ann. Rept. Iowa Geol. Survey, vol. 15.)

Union Slough (L); Kossuth County; rises in sec. 22, T. 97 N., R. 28 W.; flows north $18 \frac{1}{2}$ miles into Blue Earth River (tributary though Minnesota River to the Mississippi) in sec. 9, T. 100 N., R. 28 W.

Village Creek (R); Allamakee County; rises in T. 98 N., R. 6 W.; flows east 12 miles and northeast 5 miles into Mississippi River in T. 99 N., R. 3 W.

Village Creek (R); Wapello County; rises in T. 71 N., R. 15 W.; flows east 14 miles into Des Moines River (tributary to the Mississippi) in Wapello County, sec. 9 , T. 71 N., R. 13 W.

Volga River (R); formed by the union of two branches in Fayette County, T. 93 N., R. 9 W.; flows east 33 miles into Turkey River (tributary to the Mississippi) in Clayton County, T. 92 N., R. 4 W. Water power is developed at Volga, where a 9-foot head creates 40 horsepower, and at Mederville, where a 9-foot head creates 50 horsepower.

Wabonsie Creek (L); Mills County; rises in T. 72 N., R. 42 W.; flows southwest 18 miles into Missouri River in Fremont County, T. 69 N., R. 43 W.

Walnut Creek (L); Crawford County; rises in T. 83 N., R. 38 W.; flows north $4 \frac{1}{2}$ miles into East Boyer River in T. 83 N., R. 38 W. 
Walnut Creek (L); Dallas County; rises in T. 80 N., R. 26 W.; flows southeast 18 miles into South Raccoon River (tributary through Des Moines River to the Mississippi) in Polk County, T. 78 N., R. 25 W.

Walnut Creek (L); Fremont County; rises in sec. 3, T. 69 N., R. 40 W.; flows southwest 9 miles into Nishnabotna River (tributary to the Missouri) in T. 69 N., R. $41 \mathrm{~W}$.

Walnut Creek (R); Jasper County; rises in T. 79 N., R. 21 W.; flows southeast 12 miles into Des Moines River (tributary to the Mississippi) in Marion County, sec. 24, T. 77 N., R. 21 W.

Walnut Creek (L); Marion County; rises in sec. 31 , T. 75 N., R. 18 W.; flows east 7 miles into Cedar Creek (tributary to the Mississippi) in sec. 36, T. 75 N., R. $18 \mathrm{~W}$.

Walnut Creek (R); Poweshiek County; rises in T. 81 N., R. 16 W.; flows east 23 miles into Iowa River (tributary to the Mississippi) in Iowa County, T. 81 N., R. $12 \mathrm{~W}$.

Walnut Creek (R); Scott County; rises in T. 80 N., R. 1 E.; flows east 7 miles into Wapsipinicon River (tributary to the Mississippi) in T. 80 N., R. 2 E.

Walnut Creek (L); Shelby County; rises in T. 78 N., R. 38 W.; flows south 25 miles and southwest 37 miles into West Nishnabotna River (tributary through Nishnabotna River to the Missouri) in Fremont County, T. 69 N., R. 41 W.

Walnut Creek (R); Story County; rises in sec. 30, T. 83 N., R. 24 W.; flows southeast 7 miles into Skunk River (tributary to the Mississippi) in Story County, sec. 5 , T. 82 N., R. 23 W.

Walnut Creek (R); Wayne County; rises in T. 68 N., R. 20 W.; flows northeast 21 miles into Chariton River (tributary to the Missouri) in Appanoose County, T. 69 N., R. $18 \mathrm{~W}$.

Walnut Creek (L); Winneshiek County; rises in sec. 33, T. 99 N., R. 10 W.; flows southeast 5 miles into Tenmile Creek (tributary through Upper Iowa River to the Mississippi) in T. 98 N., R. 9 W.

Walnut Creek, Little (L); Appanoose County; rises in T. 69 N., R. 19 W.; flows east $9 \frac{1}{2}$ miles into Walnut Creek (tributary through Chariton River to the Missouri) in sec. 1, T. 69 N., R. $18 \mathrm{~W}$.

Walnut Creek, Little (L); Wayne County; rises in sec. 20 , T. 70 N., R. 20 W.; flows east and south 6 miles into South Fork of Chariton River (tributary through Chariton River to the Missouri) in sec. 36, T. 70 N., R. 20 W.

Walnut Creek, North (L); Jefferson County; rises in sec. 2, T. 73 N., R. 10 W.; flows southeast 6 miles into Walnut Creek (tributary through Skunk River to the Missiskippi) in T. 73 N., R. 9 W.

Walnut Creek, North (L); Poweshiek County; rises in T. 81 N., R. 14 W.; flows northeast $11 \frac{1}{2}$ miles into Walnut Creek (tributary through Iowa River to the Mississippi) in T. 81 N., R. 13 W.

Walnut Creek, South (R); Jefferson County; rises in sec. 29, T. 73 N., R. 10 W.; flows east $10 \frac{1}{4}$ miles into Walnut Creek (tributary through Skunk River to the Mississippi) in sec. 23, T. 73 N., R. 9 W.

Walnut Creek, South (R); Jefferson County; rises in T. 73 N., R. 10 W.; flows southeast 18 miles into Skunk River (tributary to the Mississippi) in T. 72 N., R. $8 \mathrm{~W}$.

Walnut Creek, South Fork (R); Story County; rises in T. 82 N., R. 24 W.; flows east 4 miles into Walnut Creek (tributary through Skunk River to the Mississippi) in T. 83 N., R. 24 W.

Walton Creek (L); Buchanan County; rises in sec. 10, T. 87 N., R. 7 W.; flows south 8 miles into Wapsipinicon River in Linn County, T. 87 N., R. 7 W. Total fall, about 130 feet. 
Wapsinonoc Creek (R); formed by the junction of East and West branches in - Muscatine County, sec. 24, T. 78 N., R. 4 W.; flows south 7 miles into Cedar River (tributary through Iowa River to the Mississippi) in T. 77 N., R. 4 W.

Wapsinonoc Creek, East Branch (L); Cedar County; rises in T. 79 N., R. 4 W.; flows south 12 miles into Wapsinonoc Creek (tributary through Cedar River to Ioẇa River and thus to the Mississippi) in junction with West Branch in Muscatine County, sec. 24 , T. 78 N., R. 4 W.

Wapsinonoc Creek, West Branch (R); Cedar County; rises in T. 80 N., R. 4 W.; flows southeast 11 miles into Wapsinonoc Creek (tributary through Cedar River to Iowa River and thus to the Mississippi) in junction with East Branch in Muscatine County, sec. 24, T. 78 N., R. 4 W.

Wapsipinicon River $(\mathrm{R})$; rises in Minnesota; flows into Iowa through Mitchell County, T. 100 N., R. 15 W.; then southeast 99 miles to Independence, southeast 51 miles to Anamosa, southeast 50 and east 28 miles into Mississippi River in Scott County, T. 80 N., R. 5 W. Gaging station at Stone City 1903-1913. Water power is developed at eight localities: At Anamosa a 7-foot head creates 400 horsepower; at Oxford a 7-foot head creates 400 horsepower; at McIntire an 8-foot head creates 30 horsepower; at Independence two plants with 11-foot heads, one creating 600 and the other 80 horsepower; one plant at Riceville regarding which no data are available; at Frederika a 7-foot head creates 40 horsepower; at Mills a 7-foot head creates 150 horsepower; and at Quasqueton no data are available.

Wapsipinicon River, East Branch (L); Chickasaw County; rises in T. 97 N., R. 13 W.; flows southeast 19 miles, southwest 4 miles, and south $10 \frac{1}{2}$ miles into Wapsipinicon River (tributary to the Mississippi) in Bremer County, T. 93 N., R. 12 W.

Wapsipinicon River, Little (L); Chickasaw County; rises in T. 94 N., R. 11 W.; flows south 35 miles into Wapsipinicon River (tributary to the Mississippi) in Buchanan County, T. 89 N., R. 10 W.

Wapsipincon River, Middle Branch (L); Howard County; rises in T. 99 N., R. 14 W.; flows southeast $29 \frac{1}{2}$ miles into Wapsipinicon River (tributary to the Mississippi) in Chickasaw County, T. 94 N., R. 13 W.

Ware Creek (R); Harrison County; rises in sec. 6, T. 78 N., R. 42 W.; flows south 4 miles into Potato Creek (tributary through Pigeon River to the Missouri) in sec. 30, T. 78 N., R. 42 W. (Written "Vore" on county map of Harrison County, Iowa Geol. Survey Ann. Rept., vol. 20.)

Waterman Creek (R); O'Brien County; rises in sec. 3Q, T. 97 N., R. 39 W.; flows south 24 miles into Little Sioux River (tributary to the Missouri) in O'Brien County, T. 94 N., R. 39 W.

Waterman Creek, Little (R); O'Brien County; rises in sec. 9, T. 96 N., R. 40 W.; flows southeast $6 \frac{1}{2}$ miles into Waterman Creek (tributary through Little Sioux River to the Missouri) in O'Brien County, sec. 4, T. 95 N., R. 39 W.

Weaver Creek (L); Woodbury County; rises in sec. 21 , T. 86 N., R. 44 W.; flows southwest 5 miles into Wolf Creek (tributary through West Fork of Little Sioux River to Little Sioux River and thus to the Missouri) in sec. 35, T. 86 N., R. 45 W.

Weldon River (R); Decatur County; rises in T. 70 N., R. 25 W.; flows southeast 7 miles and south 23 miles through Decatur County (T. 67 N.. R. 24 W.) into the State of Missouri.

พंest. (See also significant name.)

West Branch. (See significant name.)

West Creek (R); Poweshiek County; rises in sec. 33, T. 80 N., R. 16 W.; flows southeast 11 miles into Buck Creek (tributary through North Skunk River to Skunk River and thus to the Mississippi) in sec. 12, T. 78 N., R. $16 \mathrm{~W}$.

West Fork. (See significant name.)

Westfleld Creek (L); Plymouth County; rises in T. 92 N., R. 48 W.; flows southwest 12 miles into Big Sioux River (tributary to Missouri River) in T. 92 N., R. 49 W. 
Wheeler Creek $(R)$; formed by union of two small streams in Wright County (T.91 N., R. $23 \mathrm{~W}$.); flows northeast 6 miles into Iowa River (tributary to the Mississippi) in sec. 10, T. 91 N., R. $23 \mathrm{~W}$.

Whippoorwill Creek (R); Monroe County; rises in sec. 28, T. 72 N., R. 19 W.; flows northeast 8 miles into Cedar Creek (tributary through Iowa River to the Mississippi) in sec. 21 , T. 73 N., R. $18 \mathrm{~W}$.

Whiskey Creek (R); Plymouth County; rises in T. 91 N., R. 45 W.; flows southwest 17 miles and south 19 miles into West Fork of Little Sioux River (tributary through Little Sioux River to the Missouri) in Monona County, T. 85 N., R. 44 W.

Whiskey Creek, Little (L); Woodbury County; rises in sec. 15, T. 89 N., R. 46 W.; flows south 8 miles into Whiskey Creek (tributary through West Fork of Little Sioux River to Little Sioux River and thus to the Missouri) in sec. 25, T. 88 N., R. $46 \mathrm{~W}$.

Whiskey Run (L); Keokuk County; rises in sec. 6, T. 76 N., R. 13 W.; flows southeast 5 miles into Cedar Creek (tributary through Skunk River to the Mississippi).

Whiskey Run (R); Washington County; rises in sec. 25, T. 76 N., R. 7 W.; flows west and northwest 7 miles into Goose Creek (tributary through Iowa River to the Mississippi) in sec. 23, T. 76 N., R. 6 W.

White Breast Creek (R); Clarke County; rises in T. 72 N., R. 26 W.; flows east 7 miles to Oscea, southeast 10 miles and northeast $50 \frac{1}{2}$ miles into Des Moines River (tributary to the Mississippi) in Marion County, T. 76 N., R. 19 W.

White Breast Creek, South (R); Clarke County; rises in T. 71 N., R. 25 W.; flows east 11 miles into White Breast Creek in Clarke County, T. 71 N., R. 24 W.

White Fox Creek (L); Wright County; rises in T. 92 N., R. 24 W.; flows southwest $27 \frac{1}{2}$ miles into Boone River (tributary through Des Moines River to the Mississippi) at Websiter City, Hamilton County.

Whites Creek (R); Lucas County; rises in T. 72 N., R. 20 W.; flows northeast 10 miles into Cedar Creek (tributary through Des Moines River to the Mississippi) in sec. 28, T. 73 N., R. $18 \mathrm{~W}$.

Whitewater Creek (L); Dubuque County; rises in T. 88 N., R. 2 E.; flows southwest $4 \frac{1}{2}$ miles and south 14 miles into North Fork of Maquoketa River (tributary through Maquoketa River to the Mississippi) in Jones County, T. 86 N., R. 1 W.

Wichita Creek (R); Audubon County; rises in T. 81 N., R. 34 W.; flows southeast 18 miles into Raccoon River (tributary through Des Moines River to the Mississippi) in Guthrie County, T. 79 N., R. 31 W.

Wild Cat Creek $(\mathrm{R})$; Benton County; rises in T. 83 N., R. 11 W.; flows northeast 10 miles into Opossum Creek (tributary through Cedar River to Iowa River and thus to the Mississippi) in sec. 8, T. 84 N., R. 9 W.

Williams Creek $(\mathrm{R})$; Washington County; rises in sec. 32 , T. 74 N., R. 6 W.; flows northwest 7 miles into Crooked Creek (tributary through Skunk River to the Mississippi) in sec. 32 , T. 74 N., R. 7 W.

Willow Creek (L); Carroll County; rises in T. 84 N., R. 33 W.; flows southeast $21 \frac{1}{2}$ miles into Middle Branch of Raccoon River (tributary through Raccoon River to Des Moines River and thus to the Mississippi) in Guthrie County, T. 81 N., R. $32 \mathrm{~W}$.

Willow Creek (R); Cherokee County; rises in T. 92 N., R. 41 W.; flows south 20 miles into Little Sioux River (tributary to the Missouri) in T. 90 N., R. 41 W.

Willow Creek (R); Clay County; rises in T. 95 N., R. 38 W.; flows southeast 18 miles into Little Sioux River (tributary to the Missouri) in T. 94 N., R. 36 W.

Willow Creek (R); rises in Clear Lake, Cerro Gordo County, T. 96 N., R. 22 W.; flows east 12 miles into Lime Creek (tributary through Cedar River to Iowa River and thus to the Mississippi) at Mason City, in T. 96 N., R. 20 W. 
Willow Creek (L); Crawford County; rises in T. 83 N., R. 41 W.; flows southwest 12 miles into Willow River (tributary to the Missouri) in Monona County, T. 82 N., R. $41 \mathrm{~W}$.

Willow Creek (R); Crawford County; rises in T. 83 N., R. 41 W.; flows southwest 40 miles and south 21 miles into Boyer River (tributary to the Missouri) in Pottawattamie County, T. 77 N., R. 44 W.

Willow Creek (R); 6 miles long; rises in Fayette County and flows in a northeasterly direction into Volga River (tributary through Turkey River to the Mississippi).

Willow Creek (L); Marion County; rises in sec. 17, T. 75 N., R. 18 W.; flows southeast 2 miles into Walnut Creek (tributary through Cedar River to Des Moines River and thus to the Mississippi).

Willow Creek (L); O'Brien County; rises in sec. 27, T. 95 N., R. 42 W.; flows west 12 miles into Floyd River (tributary to the Missouri) 1 mile above Hospers in Sioux County, T. 95 N., R. 43 W.

Willow Creek (L); O'Brien County; rises in sec. 14, T. 94 N., R. 40 W.; flows southwest 12 miles into Mill Creek (tributary through Little Sioux River to the Missouri) in T. 93 N., R. $41 \mathrm{~W}$.

Willow Creek (R); Palo Alto County; rises in Silver Lake, T. 95 N., R. 34 W.; flows northeast 10 miles into West Branch of Des Moines River (tributary through Des Moines River to the Mississippi) in sec. 27, T. 96 N., R. 33 W.

Willow Creek (L); Sioux County; rises in T. 95 N., R. 43 W.; flows southwest 25 miles into Floyd River (tributary to the Missouri) 1 mile north of Lemars in Plymouth County, T. 92 N., R. 45 W.

Willow Creek (R); Story County; rises in sec. 16, T. 83 N., R. 21 W.; flows southeast 7 miles into Clear Creek (tributary through North Skunk River to Skunk River and thus to the Mississippi) in Marshall County, T. 82 N., R. 20 W.

Willow Slough (R); Fremont County; rises in T. 69 N., R. 42 W.; flows southwest 7 miles and southeast $10 \frac{1}{2}$ miles into Nishnabotna River (tributary to the Mis_ souri) in Fremont County, T. 67 N., R. 42 W.

Winans Creek (R); Worth County; rises in T. 99 N., R. 22 W.; flows south 8 miles into Lime Creek (tributary through Shellrock River to Cedar River, which discharges into the Mississippi through Iowa River) in Worth County, T. 98 N., R. $22 \mathrm{~W}$.

Wolf Creek (L); 3 miles long; rises in Clayton County and flows in a southwesterly direction into Volga River (tributary through Turkey River to the Mississippi).

Wolf Creek (L); Decatur County; rises in T. 70 N., R. 26 W.; flows southwest 4 miles into Long Creek (tributary through Grand River to the Missouri).

Wolf Creek (R); Grundy. County; rises in T. 87 N., R. 18 W.; flows south 7 miles, east 23 miles, and northeast $19 \frac{1}{2}$ miles into Cedar River (tributary through Iowa River to the Mississippi) in Blackhawk County, T. 87 N., R. 11 W.

Wolf Creek (L); Jasper County; rises in sec. 3, T. 81 N., R. 21 W.; flows south 4 miles into Indian Creek (tributary through Skunk River to the Mississippi) in sec. 20, T. 81 N., R. 21 W.

Wolf Creek (R); Jefferson County; rises in sec. 27, T. 72 N., R. 9 W.; flows southeast 4 miles and east 8 miles into Cedar Creek (tributary through Skunk River to the Mississippi) in Henry County, T. 71 N., R. 7 W.

Wolf Creek (R); Lucas County; rises in T. 71 N., R. 23 W.; flows northeast 14 miles into Chariton River (tributary through Grand River to the Missouri) in T. 71 N., R. $21 \mathrm{~W}$.

Wolf Creek (R); Story County; rises in sec. 20, T. 82 N., R. 21 W.; flows south $7 \frac{1}{2}$ miles into Clear Creek (tributary through Indian Creek to Skunk River and thus to the Mississippi) in Jasper County, T. 81 N., R. 21 W. 
Wolf Creek (L); Keokuk County; rises in sec. 29, T. 74 N., R. 12 W.; flows southeast 10 miles into Cedar Creek (tributary through Skunk River to the Mississippi) in Wapello County, sec. 5, T. 72 N., R. 12 W.

Wolf Creek (L); Warren County; rises in sec. 27, T. 74 N., R. 23 W.; flows northeast 9 miles into White Breast Creek (tributary through Des Moines River to the Mississippi) in Marion County, T. 74 N., R. 21 W.

Wolf Creek (L); Woodbury County; rises in T. 89 N., R. 43 W.; flows southwest 10 miles, south 10 miles, southwest 4 miles, and south 13 miles into West Fork of Little Sioux River (tributary through Little Sioux River to the Missouri) in Monona County, T. 84 N., R. 45 W.

Wolf Creek, East Fork (L); Woodbury County; rises in sec. 2, T. 88 N., R. 43 W.; flows south $7 \frac{1}{2}$ miles and southwest 4 miles into Wolf Creek (tributary through West Fork of Little Sioux River to Little Sioux River and thus to the Missouri) in sec. 30, T. 87 N., R. $43 \mathrm{~W}$.

Wolf Creek, Little (L); Grundy County; rises in sec. 28, T. 87 N., R. 17 W.; flows southeast and south 12 miles into Wolf Creek (tributary through Cedar River to Iowa River and thus to the Mississippi) in Tama County, sec. 5, T. 85 N., R. $16 \mathrm{~W}$.

Wood Creek (L); rises in Clayton County; a small tributary to Elk Creek in T. 91 N., R. 4 W.

Wyaconda Creek, North (L); Davis County; rises in T. 69 N., R. 13 W.; flows southeast 13 miles through Davis County into the State of Missouri, T. 67 N., R. $12 \mathrm{~W}$.

Wyaconda Creek, South (R); Davis County; rises in T. 68 N., R. 15 W.; flows southeast 19 miles through Davis County into the State of Missouri, T. 67 N., R. $12 \mathrm{~W}$.

Yancy Creek (L); Warren County; rises in sec. 29, T. 75 N., R. 23 W.; flows northeast 4 miles into Otter Creek (tributary through South River to Des Moines River and thus to the Mississippi).

Yankee Run (R); Cedar County; rises in sec. 23, T. 82 N., R. 2 W.; flows southeast 17 miles into Wapsipinicon River (tributary to the Mississippi) in T. 81 N., R. $1 \mathrm{E}$.

Yellow River (R); Winneshiek County; rises in T. 96 N., R. 8 W.; flows east $34 \frac{1}{2}$ miles into Mississippi River in Allamakee County, T. 96 N., R. 3 W. 
